\title{
NUTRIÇÃO E ECOLOGIA NUTRICIONAL DE CERVÍDEOS BRASILEIROS EM CATIVEIRO E NO PARQUE NACIONAL DAS EMAS - GOIÁS
}

AleXAndre Berndt

Tese apresentada à Escola Superior de Agricultura "Luiz de Queiroz", Universidade de São Paulo, para obtenção do título de Doutor em Ecologia de Agroecossistemas.

P I R A C I C A B A

Estado de São Paulo - Brasil

Junho - 2005 


\section{NUTRIÇÃO E ECOLOGIA NUTRICIONAL DE CERVÍDEOS BRASILEIROS EM CATIVEIRO E NO PARQUE NACIONAL DAS EMAS - GOIÁS}

\section{AleXANDRe Berndt}

Engenheiro Agrônomo

Orientador: Prof. Dr. DANTE PAZZANESE D. LANNA

Tese apresentada à Escola Superior de Agricultura "Luiz de Queiroz", Universidade de São Paulo, para obtenção do título de Doutor em Ecologia de Agroecossistemas.

P I R A C I C A B A

Estado de São Paulo - Brasil

Junho - 2005 
Dados Internacionais de Catalogação na Publicação (CIP) DIVISÃO DE BIBLIOTECA E DOCUMENTAÇÃO - ESALQ/USP

\section{Berndt, Alexandre}

Nutrição e ecologia nutricional de cervídeos brasileiros em cativeiro e no Parque Nacional das Emas - Goiás / Alexandre Berndt. - - Piracicaba, 2005. $80 \mathrm{p}$.

Tese (doutorado) - - Escola Superior de Agricultura Luiz de Queiroz, 2005. Bibliografia.

1. Avaliação nutricional e animal 2. Comportamento animal 3. Composto alifático 4. Comportamento animal 5. Digestão animal 6. Ecologia animal 7. Metabolismo animal 8. Parque nacional 9. Veado I. Título 


\section{DEDICATÓRIA}

Às famílias Berndt e Montewka pelo apoio, amizade e amor:

Pedro (in memorian), Svetlana, Alexander, Cristina, Marcelo, André, Gabriela, Michel e Ana Lúcia;

Ricardo, Fátima, Andréa e Ana Maria.

Em especial à querida Adriana pelo amor presente em todos os momentos. 


\section{AGRADECIMENTOS}

À Universidade de São Paulo pela oportunidade de ingresso na primeira turma do Programa de Pós-Graduação em Ecologia de Agroecossistemas - PPGI-EA; À Fundação de Amparo à Pesquisa do Estado de São Paulo - FAPESP pela concessão de bolsa de estudos e auxílio à pesquisa;

Ao Instituto Brasileiro de Meio Ambiente - IBAMA pelo interesse e aprovação do projeto no Parque Nacional das Emas, GO;

À Faculdade de Ciências Agrárias e Veterinárias - FCAV/UNESP pela oportunidade e apoio no experimento com cervídeos em cativeiro; Aos doutores Dante Pazzanese Lanna, José Maurício Barbanti Duarte, Marcelo Zacharias Moreira e Dimas Estrásulas de Oliveira pela orientação;

Aos colegas do Laboratório de Nutrição e Crescimento Animal - LNCA pela amizade e colaboração;

Aos técnicos do IBAMA, IZ, FCAV e ESALQ pela ajuda na condução dos experimentos; 


\section{SUMÁRIO}

RESUMO

Página

SUMMARY

1 INTRODUÇÃO

2 REVISÃO DE LITERATURA.................................................................. 3

2.1 Cervídeos: aspectos gerais......................................................................... 3

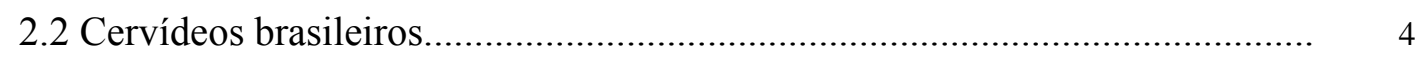

2.3 Parque Nacional das Emas....................................................................... 7

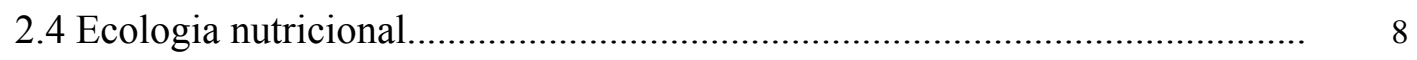

2.5 Exigências nutricionais e digestibilidade.................................................. $\quad 10$

2.6 Técnica da água duplamente marcada.......................................................... 11

2.7 Técnica de isótopos de carbono............................................................... 14

2.8 Técnica de n-alcanos............................................................................... 16

3 DETERMINAÇÃO DA DEMANDA DE ENERGIA DO VEADOCATINGUEIRO (MAZAMA GOUAZOUBIRA) EM CATIVEIRO ATRAVÉS DO MÉTODO DA ÁGUA DUPLAMENTE MARCADA ................................. 21

3.1 Introdução ........................................................................................... 22

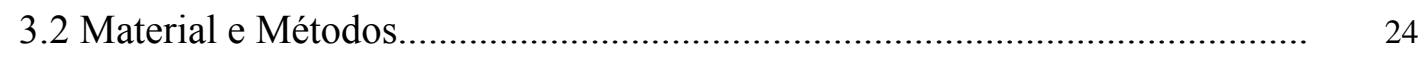

3.3 Resultados e Discussão ......................................................................... $\quad 30$

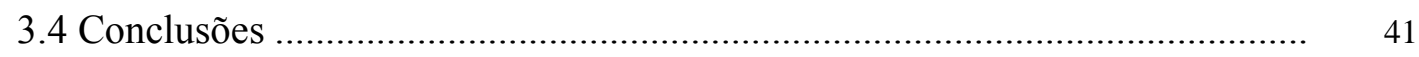

4 ECOLOGIA NUTRICIONAL DO VEADO-CAMPEIRO (OZOTOCEROS BEZOARTICUS) NO PARQUE NACIONAL DAS EMAS, GO..................... 43

4.1 Introdução ............................................................................................. 45

4.2 Material e Métodos.................................................................................... 46

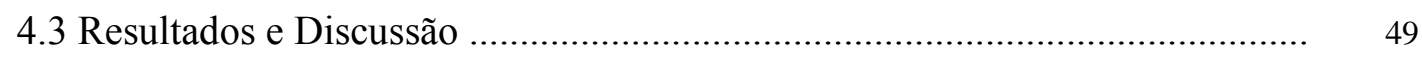


4.4 Conclusões

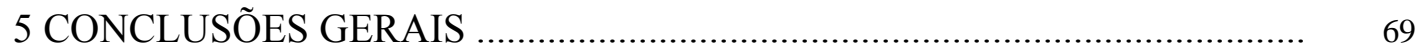

REFERÊNCIAS BIBLIOGRÁFICAS …..................................................... 71 


\title{
NUTRIÇÃO E ECOLOGIA NUTRICIONAL DE CERVÍDEOS BRASILEIROS EM CATIVEIRO E NO PARQUE NACIONAL DAS EMAS - GOIÁS
}

\author{
Autor: ALEXANDRE BERNDT
}

Orientador: Prof. Dr. DANTE PAZZANESE D. LANNA

\section{RESUMO}

Existem poucas informações sobre exigências de energia de cervídeos brasileiros, dificultando o sucesso de manejo e reprodução em cativeiro. $\mathrm{O}$ conhecimento das exigências de energia também é importante para determinar os recursos necessários para sua conservação em parques e reservas. O primeiro objetivo deste experimento foi estudar as exigências nutricionais do veado catingueiro (Mazama gouazoubira) em cativeiro. O segundo objetivo foi observar o comportamento alimentar do veado-campeiro (Ozotoceros bezoarticus) no Parque Nacional das Emas (PNE), descrevendo qualitativamente e quantitativamente as principais espécies vegetais utilizadas para o aporte de nutrientes. A determinação das exigências de energia para mantença utilizou 8 veados-catingueiro de ambos os sexos em cativeiro e foi desenvolvida através de dois métodos: a)equilíbrio de peso e b)água duplamente marcada $\left({ }^{2} \mathrm{H}_{2}{ }^{180}\right)$. Os animais foram dosados com água duplamente marcada $\left(111,8 \mathrm{mg} / \mathrm{kgPV}\right.$ para ${ }^{2} \mathrm{H}_{2} \mathrm{O}$ e $163,1 \mathrm{mg} / \mathrm{kgPV}$ para $\left.\mathrm{H}_{2}{ }^{18} \mathrm{O}\right)$ e amostras de sangue foram coletadas em intervalos de 3 dias, até que 3 ou 4 meiasvidas dos isótopos tenham decorrido (atingindo o limite de detecção em aproximadamente 30 dias após a dosificação). As curvas de desaparecimento dos isótopos em função do tempo foram utilizadas para calcular o "turnover" de $\mathrm{CO}_{2} \mathrm{e}$ 
$\mathrm{H}_{2} \mathrm{O}$. Os resultados obtidos pelos dois métodos foram semelhantes $(111,4$ e 112,0 $\mathrm{kcal} / \mathrm{kg}^{.75} . \mathrm{d}$ ) comprovando que a técnica da água duplamente marcada pode ser utilizada em estudos nutricionais de cervídeos. Informações de doses (mg/kgPV) e intervalo máximo entre aplicação e coleta de sangue (30 dias), permitem o uso desta metodologia em estudos futuros em vida livre. No PNE, veados-campeiro já monitorados com radio colares, permitiram a observação de seu comportamento alimentar. O experimento foi realizado em duas épocas distintas (inverno e verão). As espécies foram analisadas quanto à composição nutricional, para estimar valores energéticos assim como consumo de minerais e proteína. As contribuições das diferentes espécies que compõem a dieta dos cervídeos foram estimadas para duas populações em vida livre, uma com acesso apenas a espécies nativas (área central do parque) e outra com acesso às espécies cultivadas na periferia do PNE. Os sinais isotópicos do carbono 13 e os perfis de n-alcanos foram utilizados para quantificar a contribuição das diferentes espécies ingeridas. Os resultados indicaram que os veados-campeiro utilizam uma ampla gama de partes e espécies vegetais. Sua dieta é composta por aproximadamente 78 ítens, divididos em brotos $(38,5 \%)$, folhas $(15,4 \%)$, flores $(17,9 \%)$, botões florais $(12,8 \%)$, frutos e sementes $(15,4 \%)$; de 55 diferentes espécies nativas e 7 culturas agrícolas. Há grande diferença no padrão de consumo entre as populações no interior do parque e aquelas que tem possibilidade de selecionar plantas cultivadas pelo homem. As espécies agrícolas podem contribuir com até 46,9\% da dieta dos cervídeos da periferia do parque. Este trabalho determinou as exigências de energia de cervídeos brasileiros, validou o uso de uma técnica indireta para futuros estudos em vida livre e descreveu as espécies e partes utilizadas como aporte de nutrientes por cervídeos em vida livre.

Palavras-chave: Exigências Nutricionais; Cervídeos Brasileiros, Parque Nacional das Emas, n- alcanos, Água Duplamente Marcada. 


\section{NUTRITION AND NUTRITIONAL ECOLOGY OF BRAZILIAN CERVIDS IN CAPTIVITY AND IN THE EMAS NATIONAL PARK - GOIAS}

Author: ALEXANDRE BERNDT

Adviser: Prof. Dr. DANTE PAZZANESE D. LANNA

\section{SUMMARY}

There are limited data on energy requirements of brazilian cervids. Thus, it is difficult to succeed in their management and reproduction in captivity. Knowing the energy requirements is also important to determine the necessary nutritional resources for their conservation in parks and reserves. The first objective was to study the nutritional requirements of the grey-brocket deer (Mazama gouazoubira) in captivity. The second objective was to observe the feeding behavior of the pampas-deer (Ozotoceros bezoarticus) in the Emas National Park (ENP), describing qualitatively and quantitatively the main vegetal species used to supply these animals with nutrients. The determination of energy requirements for maintenance used 8 gray-brocket deer of both sexes in captivity and was carried through two methods: a)weight equilibrium and b)double-labeled water $\left({ }^{2} \mathrm{H}_{2}{ }^{18} \mathrm{O}\right)$. The animals were dosed with double-labeled water $\left(111.8 \mathrm{mg} / \mathrm{kgBW}\right.$ for ${ }^{2} \mathrm{H}_{2} \mathrm{O}$ and 163.1 $\mathrm{mg} / \mathrm{kgBW}$ for $\mathrm{H}_{2}{ }^{18} \mathrm{O}$ ) and blood samples were collected with 3 days interval, until 3 or 4 half lives of isotopes had occurred (reached limit of detection at approximately 30 days after the dosage). The curves of isotopes disappearance as a function of time were used to calculate the turnover of $\mathrm{CO}_{2}$ and $\mathrm{H}_{2} \mathrm{O}$. The results obtained from the two methods were similar (111.4 and $\left.112.0 \mathrm{kcal} / \mathrm{kg}^{.75} . \mathrm{d}\right)$ proving the double-labeled water technique may be used in nutritional studies of cervids. Information on doses 
$(\mathrm{mg} / \mathrm{kgBW})$ and maximum interval between injection and blood collection (30days), allow the use of this methodology in future studies with free ranging deer. In the national park, pampas-deer already monitored with radio colars, facilitated the observation of their feeding behavior. The experiment was conducted at two distinct seasons (winter and summer). The species were analyzed for the nutritional composition, to estimate energy values as well as mineral and protein consumption. The contributions of the different species to the diet of the cervids were estimated for two free ranging populations of the national park, one with access only to native species (central area of the park) and another with access to the crop species cultivated in the periphery of the park. The isotopic signals of carbon 13 and profiles of n-alkanes were used to quantify the contribution of different species to supply the energy demands. The results indicated that pampas-deer feeds on a broad spectrum parts and vegetal species. Its diet was composed of approximately 78 different parts, divided in sprouts $(38.5 \%)$, leaves $(15.4 \%)$, flowers $(17.9 \%)$, floral buttons $(12.8 \%)$, fruits and seeds (15.4\%); from 55 different native species and 7 agricultural cultures. There is a great difference in the intake selection patterns between populations in the interior of the park and those that have access to cropland and the opportunity to choose feeding on native or cultivated plants. The agricultural species can contribute with up to $46.9 \%$ of deer diet of the park periphery. This work determined the requirements of energy of Brazilian cervids, validated the use of one indirect technique for use in free ranging animals and described the species and parts used to supply nutrients to cervids in the wild.

Key-words: Nutritional requirements; Brazilian cervids; Emas National Park; n-alkanes; double-labeled water 


\section{INTRODUÇÃO}

As espécies de cervídeos existentes no Brasil vêm apresentando acentuado declínio populacional, principalmente devido à alteração e perda de habitat, doenças e caça indiscriminada.

Há um crescente interesse em estudar os cervídeos, sobretudo pela necessidade de manutenção e preservação de áreas naturais para conservação destas espécies, bem como a possibilidade de criação em cativeiro. Conhecendo aspectos reprodutivos, comportamentais e nutricionais destes animais, especialmente as exigências de nutrientes das diferentes categorias, podemos estimar a quantidade e qualidade de habitat que precisamos reservar para preservar o veado-campeiro.

As técnicas de alimentação controlada por longo período e da água duplamente marcada foram utilizadas no ensaio 1 para determinar as exigências de energia para mantença de veados-catingueiro em cativeiro.

Para identificar as contribuições parciais das diferentes espécies vegetais ingeridas nas dietas dos veados-campeiro no PNE e verificar se os animais utilizam culturas agrícolas na sua dieta utilizaram-se duas técnicas: sinais isotópicos do carbono e n-alcanos. O acompanhamento dos grupos de veados-campeiro no PNE para a coleta de plantas ingeridas e fezes permitiu a identificação de diferentes aspectos relacionados às áreas de comportamento nutricional e aporte de nutrientes.

Este projeto insere-se num amplo estudo da biologia de cervídeos brasileiros que pretende auxiliar na compreensão da biometria dos animais, sistemática, citogenética, parasitologia, reprodução, uso de habitat, entre outros. A parceria da FCAV/UNESP com a ESALQ e CENA/USP permite a complementaridade entre grupos de pesquisa. Estes conhecimentos multidisciplinares de cada grupo são fundamentais para uma compreensão mais abrangente de como o comportamento 
nutricional é importante na vida e na conservação destas espécies. Os resultados deste projeto poderão ser utilizados diretamente para animais em cativeiro, como zoológicos e criadores conservacionistas, além de constituírem indicadores para estimativas de recursos necessários nas unidades de conservação destinadas à manutenção destas espécies. 


\section{REVISÃO DE LITERATURA}

\subsection{Cervídeos: Aspectos Gerais}

Os cervídeos são animais da ordem dos Artiodactyla, que se caracterizam pela presença de cascos. Os cervídeos são os ruminantes selvagens mais distribuídos no mundo, sendo encontrados em quase todos os continentes, exceto na Antártida (Van Soest, 1994). No mundo existem 17 gêneros e 45 espécies de cervídeos distribuídos nas Américas, Europa, Ásia e África (Walker, 1991).

$\mathrm{Na}$ maioria dos cervídeos, os machos apresentam chifres, com exceção dos animais do gênero Moschus e da espécie Hydropotes inermis (Eisenberg, 1999). Os chifres são formados a partir do osso frontal, sendo estes recobertos por um "velame" durante sua fase de crescimento. O "velame" tem como função depositar cálcio na matriz óssea do chifre durante o período de crescimento (Duarte, 1997). A deposição de chifres é um processo de grande demanda energética e que gera uma necessidade de maior aporte de nutrientes (Geist, 1991).

Sendo classificados como ruminantes, os cervídeos apresentam estômago dividido em quatro compartimentos: rúmen, retículo, omaso e abomaso. $\mathrm{O}$ alimento ingerido é primeiramente mastigado, passando do esôfago para o rúmen e retículo, onde existem populações de microrganismos. Em seguida o alimento pode retornar para a cavidade oral onde é remastigado e enviado de volta ao rúmen e subseqüentemente para o omaso e abomaso onde sofrerá ação de enzimas digestivas do hospedeiro (Church, 1993). O principal efeito da microbiota ruminal é degradar a parede celular dos vegetais, produzindo como resultado desta fermentação os ácidos graxos voláteis, que são absorvidos pela parede do rúmen fornecendo energia ao animal. 
Embora menos numerosos do que os ruminantes domésticos, os ruminantes silvestres também são importantes para os humanos e para manutenção da estabilidade de diferentes ecossistemas. Algumas espécies estão ameaçadas e seu número está sendo drasticamente reduzido principalmente pela perda de "habitat", doenças e caça ilegal em ambientes fragmentados. Nem todos os ruminantes selvagens estão em risco de extinção. O veado-de-cauda-branca (Odocoileus virginianus) coexiste muito bem com humanos, mesmo em áreas suburbanas, e há provavelmente mais indivíduos desta espécie no leste da América do Norte atualmente do que em todos os tempos. Esta espécie se adapta muito bem às transformações do ambiente pelo homem, usando as áreas agrícolas como fonte de alimento e o mosaico destas áreas agrícolas, como fragmentos e reservas de matas, para proteção (Verme \& Ullrey, 1984; Wemmer, 1982).

Embora a exploração pela caça regulada tenha aumentado o número de indivíduos desta espécie, outras espécies não se adaptam tão bem à ocupação humana e à transformação e antropomorfização do habitat natural, exigindo proteção total para não se extinguirem (Van Soest, 1994).

\subsection{Cervídeos brasileiros}

\subsubsection{Veado-catingueiro - Mazama gouazoubira}

Os veados-catingueiro habitam predominantemente áreas de floresta (Pinder, 1997). A maior parte da dieta destes animais é constituída de frutos, uma vez que em florestas com muitas espécies esses estão disponíveis o ano inteiro. Já as flores e folhas podem ser eventualmente consumidas (Duarte, 1997). A disponibilidade estacional dos diversos tipos de frutos se reflete no consumo das diferentes espécies pelo catingueiro. Desta forma, durante a estação seca, o veado-catingueiro se alimenta de frutos secos e fibrosos, e na estação úmida de frutos suculentos e macios. Nas florestas tropicais, as sementes de palmeiras constituem importante fonte de energia para estas espécies tipicamente seletoras de alimentos concentrados (“concentrate selectors") ou "browsers" (Bodmer, 1989). 
Não há uma explicação concreta para a função do rúmen para animais frugívoros de pequeno porte, tais como os veados-catinqueiro (Mazama gouazoubira) e outras espécies do gênero Mazama, pois os ruminantes são menos eficientes do que os não ruminantes quando esses se alimentam com dietas de baixas fibras como as frutas (Foose, 1982; Demment \& Van Soest, 1985; Oliveira \& Duarte, 2003). Uma das respostas para o uso do rúmen nestes animais seria que muitas das espécies de frutos consumidos possuem sementes extremamente fortes, com seu ponto de quebra atingindo até $150 \mathrm{Kg}$. Os Mazama engolem as sementes inteiras, capacitando assim a microbiota do rúmen-retículo para amolecer e digerir estas sementes (Bodmer, 1989). Outra função do rúmen para os Mazama seria que, na ausência de frutos durante as estações mais secas em determinadas regiões, eles teriam condições de sobreviver substituindo-os por uma dieta de brotos (Branan et al, 1985). Outra possibilidade seria a detoxificação de taninos e outros compostos (Van Soest, 1994).

Ao contrário da alimentação em vida livre, podemos observar que a maioria dos veados-catingueiro encontrados em zoológicos e parques consome uma dieta à base de gramíneas e leguminosas com resultados desanimadores de mortes por inanição ou doenças decorrentes. Por serem de tamanho reduzido têm um metabolismo mais acelerado e, sendo ruminantes, têm uma limitação anatômica e fisiológica à passagem de alimento. Se não conseguem comer muito de alimentos pobres e fibrosos para suprir suas exigências precisam ingerir alimentos densos energeticamente e facilmente digestíveis que são aproveitados ao máximo. Estas particularidades despertaram o interesse de se estudar a capacidade de consumo e digestão destes animais nestas condições de forma a suprir suas exigências energéticas e contribuir para o sucesso nas criações em cativeiro.

\subsubsection{Veado-campeiro - Ozotoceros bezoarticus}

O veado-campeiro ocupa uma grande diversidade de ambientes e pode ser encontrado em ambientes úmidos e secos, cerrado aberto e fechado, mas não em florestas fechadas (Duarte, 1997). Redford (1987), trabalhando com o veado- 
campeiro no Parque Nacional das Emas, pôde notar a preferência destes animais por campos abertos.

O peso adulto nesta espécie está entre 28 e $35 \mathrm{~kg}$, dependendo do sexo, da subespécie e período do ano (Duarte, 1997). Seu tamanho é um pouco maior que dos veados-mateiro e catingueiro (gênero Mazama), sendo inconfundível por possuir um pelame baio e, assim como o cervo-do-pantanal, lanoso.

A distribuição original do veado campeiro na América situava-se entre as latitudes $5^{\circ}$ e $41^{\circ} \mathrm{S}$, em áreas abertas como campos cerrados. É considerada uma espécie ameaçada principalmente pela perda de habitat e pela caça indiscriminada. Nas últimas décadas os campos nativos e os cerrados vêm sendo destruídos para formação de pastagens e agricultura (Braga, 1999). O veado-campeiro está na lista oficial de espécies da Fauna Brasileira ameaçada de extinção, publicada em 1989 (IBAMA, 1989).

$\mathrm{Na}$ Argentina, assim como no Brasil, as populações restantes de veados-campeiro estão fragmentadas (Jackson \& Langguth, 1987; Merino \& Carpinetti, 1998), devido à caça e ao desenvolvimento da agricultura e da pecuária. Em 2002 existiam apenas 4 populações isoladas de veado-campeiro na Argentina (Pautasso \& Peña, 2002).

A população de veados-campeiro no Brasil foi estimada em aproximadamente 20.000 animais em 1994 (Wemmer, 1994). No Parque Nacional das Emas a população foi estimada entre 1000 e 1300 indivíduos (Redford, 1987; Rodrigues, 2003).

O Veado Campeiro foi considerado extinto no estado do Paraná até que em 1996 foi localizada uma população isolada numa reserva particular. Estudo realizado por Braga et al. (2000) identificou grupos isolados no Estado.

As populações de veado campeiro que habitam fragmentos preservados de campos nativos ou campos cerrados em áreas particulares estão associadas a fazendas que desenvolvem atividades de agricultura ou pecuária e oferecem uma maior disponibilidade de alimento durante praticamente todo o ano. Nestes casos as áreas preservadas servem de abrigo e local de descanso (Braga, 2002).

Segundo Rodrigues \& Monteiro-Filho (1999) estudando a composição de forragem disponível no PNE, as gramíneas constituem o grupo mais abundante nas amostragens, seguidas por herbáceas e arbustos. Flores foram responsáveis pela menor 
fração disponível no período. As categorias mais ingeridas foram herbáceas e flores, seguidos por arbustos e gramíneas. Apesar da diversidade de itens disponíveis os animais ingeriram preferencialmente as partes mais tenras e suculentas, como folhas, brotos e flores.

O veado campeiro prefere flores, folhas e brotos de dicotiledôneas ao invés de gramíneas. Embora as populações de veado campeiro da Argentina se alimentem preferencialmente de gramíneas (Jackson \& Giulietti, 1988; Merino \& Carpinetti, 1998) no PNE estas são raramente ingeridas, apesar de sua grande abundância. O veado campeiro no PNE apresenta comportamento característico de browser segundo a classificação proposta por Bodmer (1990), ingerindo preferencialmente espécies herbáceas, buscando as porções mais nutritivas das plantas.

\subsection{Parque Nacional das Emas}

O Parque Nacional das Emas, localizado no município de Mineiros, sudoeste do Estado de Goiás, entre as latitudes $17^{\circ} 50^{\prime}$ e $18^{\circ} 23^{\prime} \mathrm{S}$ e longitudes $52^{\circ} 43^{\prime}$ e $53^{\circ} 09^{\prime} \mathrm{W}$, Planalto Central do Brasil é a maior reserva federal de Cerrado compreendo 131.868 ha. As propriedades circunvizinhas ao parque são voltadas à pecuária e agricultura intensiva de soja, milho, algodão e sorgo, intercaladas com milheto, girassol, amendoim e outras culturas. O clima caracteriza-se por uma marcante estação seca de abril a setembro com registros de baixas temperaturas e eventuais geadas. No verão as temperaturas são elevadas assim como a precipitação anual que alcança em média 1.500mm (Frutuoso, 1999).

No Parque Nacional das Emas todas fisionomias vegetais do cerrado estão representadas sendo que aproximadamente $60 \%$ do parque é composto por campos cerrados (Batalha, 2001; Batalha \& Martins, 2002). Incêndios naturais são comuns, especialmente nas primeiras tempestades com raios após a estiagem. Em agosto de 1994 um incêndio destruiu mais de 90\% da área do Parque matando animais (Silveira et al, 1999) e reduzindo drasticamente a disponibilidade de alimento (Rodrigues, 1996c). Após as queimadas a vegetação do cerrado apresenta intensa 
rebrota e as áreas recém queimadas atraem os veados-campeiro devido à alta disponibilidade de alimento. Esta atração pode persistir por alguns meses após o fogo (Rodrigues, 1996c).

O Parque é servido de várias estradas internas e periféricas, paralelas aos aceiros, que delimitam extensas áreas contínuas de vegetação típica de cerrado. A presença de aceiros, constantemente queimados pelos funcionários do Ibama e Brigada de Incêndio evita a dispersão descontrolada de incêndios e facilita significativamente a visualização de grupos de veados pois a intensa rebrota atrai os animais.

O Parque Nacional das Emas possui uma das maiores populações de veadoscampeiro do cerrado e foi estimada em 1994, logo após o grande incêndio, em cerca de 1300 indivíduos (Rodrigues, 2003) pouco acima dos 1000 indivíduos estimados por Redford (1987).

\subsection{Ecologia Nutricional}

Ecologia nutricional é a ciência que relaciona um animal com seu habitat através de interações nutricionais (Parker, 2003). As estratégias que os cervídeos usam para atender às exigências nutricionais variam de acordo com a espécie animal e com aspectos geográficos e sazonais do habitat.

Um esforço considerável foi feito na última década para quantificar especificamente as exigências de energia de cervídeos buscando compreender as interrelações entre consumo de forragem, uso de habitat, estações do ano e balanço energético. A maioria dos estudos foi conduzida com espécies de clima temperado onde as estações do ano são acentuadas e as baixas temperaturas são marcantes (Adamczewski et al., 1993; Cook et al., 1998; Gotaas et al., 2000a e 2000b; Haggarty et al., 1998; Midwood et al., 1993; Parker et al., 1999).

$\mathrm{O}$ consumo de alimentos e o incremento calórico associado à fermentação ruminal durante o inverno podem reduzir o custo da termoregulação e reduzir o catabolismo de tecido corporal em cervídeos de clima temperado (Jensen et al., 1999). Para o veado-de-cauda-branca (Odocoileus virginianus) pastando em ambiente natural, o 
incremento na produção de calor resultante da ingestão de forragem reduziu a temperatura de stress em aproximadamente $10^{\circ} \mathrm{C}$. Dietas com alta digestibilidade e elevado consumo de matéria seca estão relacionadas com maior produção de calor (Robbins, 1993). A faixa adequada de termoneutralidade para diferentes espécies de cervídeos depende também da idade, peso e pelagem. A maioria dos estudos desenvolvidos buscou definir o limite crítico inferior de temperatura e não o superior, justamente pelo maior esforço de entendimento para as espécies temperadas.

O impacto de invernos rigorosos no balanço energético das espécies de cervídeos de climas temperados é marcante mas também é preciso reconhecer que a abundância de forragem de qualidade no verão é fundamental para a reposição e acúmulo de reservas corporais (Adamczewski et al., 1993; Cook et al., 1998). Nas espécies de cervídeos tropicais este fato também pode ser inferido, embora de forma mais sutil, entre as estações seca e chuvosa.

Nas regiões tropicais, especialmente nas savanas e no cerrado a grande restrição no inverno é a escassez de chuvas que determina os ciclos de desenvolvimento das espécies vegetais e conseqüentemente dos herbívoros relacionados.

Em qualquer continente, região ou espécie a forma com que os animais percebem seu ambiente e tomam decisões de forrageamento são importantes para o entendimento das interações entre animais e plantas (Parker, 2003). O comportamento alimentar das espécies é dependente da distribuição espacial e da disponibilidade quantitativa e qualitativa do alimento. Em ruminantes as principais restrições ao consumo de alimento são a qualidade da forragem que afeta o tempo de retenção no rúmen; e a disponibilidade da forragem que determina a velocidade de enchimento do rúmen.

Diversos estudos procuram entender as alterações no comportamento alimentar e a forma com que as espécies determinam o local de pastejo e a biomassa ideal de forragem. Duas teorias principais são discutidas: a da maximização do consumo de energia e a da minimização do tempo de pastejo. Segundo Bergman et al. (2001) estas duas teorias não são necessariamente excludentes mas se ajustam a diferentes características do ambiente. $\mathrm{O}$ consumo acelerado em ambientes com alta biomassa reduz o tempo de pastejo mas também reduz a taxa de passagem no rúmen pois a 
forragem ingerida é de baixa qualidade devido à falta de seleção. Uma seleção de alimentos mais digestíveis com maior conteúdo celular e menos fibra estrutural (parede celular) permite um maior aproveitamento da forragem e maior consumo de energia, porém demanda maior tempo de pastejo. Bergman et al. (2001) propõem que o animal pasteja tempo suficiente para suprir as exigências de energia e utiliza o resto do tempo em outras atividades importantes como termoregulação (pastejo é deprimido sob stress térmico), reprodução, comportamento social (machos dominantes defendem mais o território e copulam com mais fêmeas) e vigília a predadores (animais vigilantes levantam mais a cabeça e consequentemente pastejam menos).

A eficiência energética do comportamento alimentar dos cervídeos, isto é, a relação entre a energia ingerida e a energia gasta na busca de alimento determina a ligação entre a disponibilidade de recursos do habitat e a condição corporal do animal (Parker et al. 1996).

\subsection{Exigências Nutricionais e Digestibilidade}

As exigências de energia podem ser arbitrariamente divididas em exigência líquida para mantença e exigência líquida para crescimento (Lofgreen \& Garret, 1968). As exigências de mantença podem ser definidas como aquelas necessárias à manutenção dos processos vitais (manutenção dos gradientes das membranas, síntese de macromoléculas, manutenção da homotermia) e atividade física mínima necessária à sobrevivência (busca de alimento). As exigências para crescimento são aquelas destinadas às funções de reprodução, lactação, fuga de predadores ou crescimento.

A energia é o mais importante elemento em termos nutricionais. Os dois fatores determinantes da eficiência de utilização da energia pelos ruminantes são perda nas fezes e produção de calor. A perda nas fezes está relacionada a características de digestibilidade dos alimentos e consumo de alimento. A produção de calor, por sua vez, está relacionada à exigência de energia líquida para mantença 
e à ineficiência dos processos de síntese e deposição de proteínas e gordura (Lanna, 1997).

A determinação das exigências de energia para mantença e crescimento de cervídeos é importante pois a maior parte da energia bruta obtida pelo animal é utilizada em funções de mantença. Quando um animal está crescendo ou em fase reprodutiva, a ingestão de energia precisa ser aumentada para suprir o incremento da demanda destes processos. A forma como um animal age para suprir essa demanda determina sua estratégia de uso dos recursos do habitat. Para ingerir mais energia o animal pode: 1) ingerir maior quantidade de alimento ou 2) ingerir alimentos mais densos energeticamente em menor quantidade.

Os cervídeos por serem ruminantes têm peculiaridades que afetam diretamente seu comportamento alimentar. O rúmen apresenta vantagens pois possibilita a extração de nutrientes de alimentos fibrosos através da associação com microrganismos. Por outro lado também tem limitações, principalmente quanto ao tempo de retenção e taxas de passagem dos alimentos.

Se o animal precisa ingerir mais energia e não pode obtê-la de alimentos excessivamente fibrosos (que tem baixo valor nutricional e baixa taxa de passagem) ele buscará alimentos mais digestíveis e ricos. Neste caso ele optará por brotos, ramos suculentos, frutos ou flores (Rodrigues, 1996a). A estratégias nutricionais e o comportamento vão variar em função da demanda de energia nas diferentes fases da vida (crescimento, gestação, lactação, crescimento de chifres, defesa de território) e da disponibilidade de recursos (estação do ano, diversidade vegetal, água, abrigo).

\subsection{Técnica da Água Duplamente Marcada}

A determinação das exigências de energia de um animal pode ser obtida através de três metodologias consideradas básicas: 1) pela medição da produção de calor; 2) através de abates comparativos ou 3) alimentar o animal por longos períodos de tempo acompanhando peso e composição corporal. A medição da produção de calor pode ser diretamente determinada por calorimetria ou 
indiretamente com a técnica da água duplamente marcada. Este método menos invasivo baseia-se no princípio de que animais consomem oxigênio para liberar energia dos alimentos através da oxidação gerando água e gás carbônico. Medindose o total de $\mathrm{O}_{2}$ consumido (ou $\mathrm{CO}_{2}$ produzido) determinamos indiretamente o gasto de energia (Lifson et al., 1955; Speakman e Racey, 1988). Este quarto método é mais prático, principalmente pela relativamente fácil coleta de amostras para determinação do conteúdo de $\mathrm{O}_{2}$ e $\mathrm{CO}_{2}$. Também é um método não invasivo de amostragem, adequado quando se trabalha com espécies ameaçadas de extinção como os cervídeos. A maior dificuldade no uso desta técnica é o alto preço da água enriquecida com os isótopos estáveis, especialmente o oxigênio $18-{ }^{18} \mathrm{O}$ (US\$ 150,00 por grama).

Para determinar a produção de calor podemos utilizar a produção de $\mathrm{CO}_{2}$ estimada à partir do método da água duplamente marcada que é baseado nas taxas relativas de decréscimo nas concentrações de água enriquecida com oxigênio 18 $\left(\mathrm{H}_{2}{ }^{18} \mathrm{O}\right)$ e água enriquecida com deutério $\left({ }^{2} \mathrm{H}_{2} \mathrm{O}\right)$ no total de água corporal (Holleman et al., 1982). O princípio básico de se enriquecer o total de água corporal com água duplamente marcada está fundamentado no fato de que a taxa de desaparecimento (“turnover") do ${ }^{18} \mathrm{O}$ é maior que a do ${ }^{2} \mathrm{H}$ porque ambos elementos são perdidos do corpo através da água, mas apenas o ${ }^{18} \mathrm{O}$ é também perdido na expiração de $\mathrm{CO}_{2}$ (Torien et al., 1999).

$\mathrm{O} \mathrm{O}_{2}$, no balanço respiratório com o $\mathrm{CO}_{2}$, se equilibra com o $\mathrm{O}_{2}$ da água corporal sob influência aceleradora da anidrase carbônica. A taxa de desaparecimento da $\mathrm{H}_{2}{ }^{18} \mathrm{O}$ da água é relacionada à perda combinada de $\mathrm{CO}_{2}$ e de água corporal, enquanto a perda de ${ }^{2} \mathrm{H}_{2} \mathrm{O}$ é relacionada apenas à perda de água. $\mathrm{A}$ produção de $\mathrm{CO}_{2}$ é calculada pela diferença (dividida por dois) entre as taxas fracionais de desaparecimento dos isótopos de oxigênio e hidrogênio (Figura 1) e por estimativa do volume total de água corporal do animal (Nagy, 1980). A diferença entre as taxas dos isótopos precisa ser dividida ao meio pois dois átomos de oxigênio de duas moléculas de água se unem para formar uma molécula de gás carbônico. 


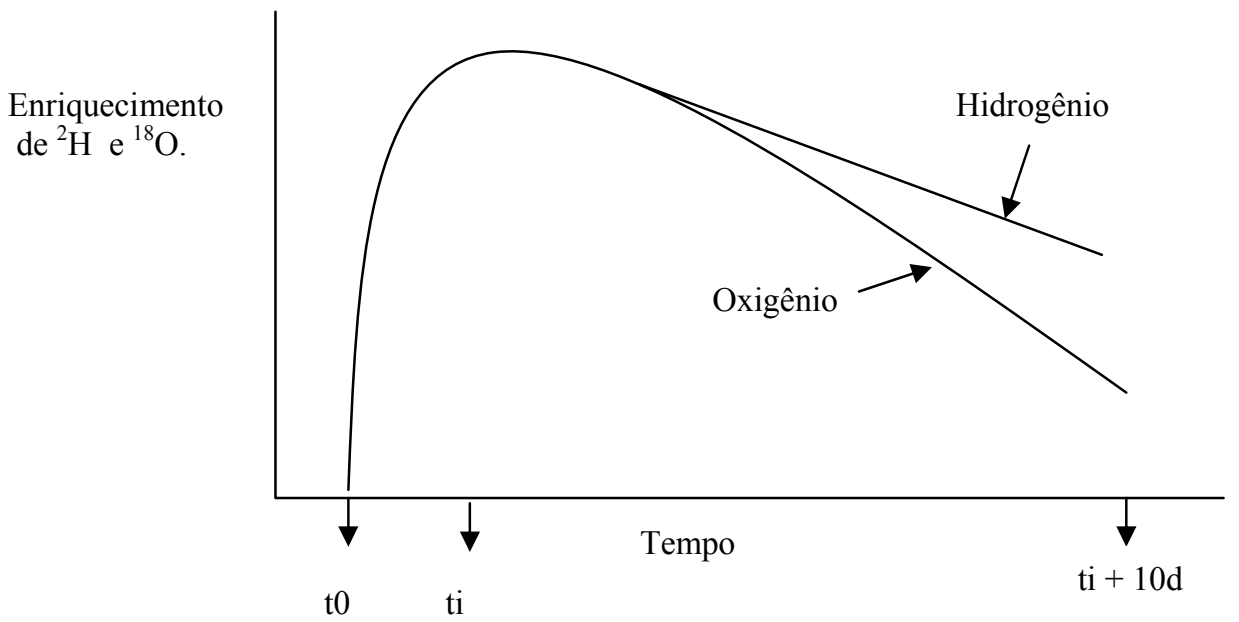

Figura 1 - Alterações no enriquecimento dos isótopos de hidrogênio $\left({ }^{2} \mathrm{H}\right)$ e oxigênio $\left({ }^{18} \mathrm{O}\right)$ ao longo do tempo, em um experimento de dosificação com água duplamente marcada (adaptado de Speakman e Racey, 1988)

O método de análise de dois pontos tem sido recomendado mais freqüentemente em estudos com pequenos animais, sendo particularmente apropriado para uso em animais de vida livre, mantidos em seu habitat, onde a coleta de numerosas e periódicas amostras seria impraticável (Midwood et al., 1994). O ponto inicial para utilização da regressão (ti) ocorre após o equilíbrio na diluição dos isótopos e o ponto final corresponderia de 2 a 4 vidas-médias dos isótopos. Dez dias de período experimental equivalem a cerca de 3 vidas-médias destes isótopos.

Existem alguns ajustes necessários para o uso da técnica da água duplamente marcada em ruminantes pois não é correto assumir que $100 \%$ do hidrogênio e do oxigênio é eliminado exclusivamente através da água $\left(\mathrm{H}_{2} \mathrm{O}\right)$ e do gás carbônico $\left(\mathrm{CO}_{2}\right)$. $\mathrm{O}$ hidrogênio também pode ser seqüestrado no tecido adiposo do animal quando em crescimento ou lactação (Midwood et al., 1993). Também podem ocorrer perdas significativas de hidrogênio nas fezes (Gotaas, 2000a). A produção de metano tem relação direta com a ingestão de forragem e também pode remover hidrogênio do "pool” de hidrogênio corporal (Midwood et al., 1989; Parker, 2003). 
Em algumas épocas do ano o $\mathrm{CO}_{2}$ pode ser seqüestrado durante o crescimento de ossos e chifres, afetando o turnover do oxigênio (Nagy, 1980; Parker, 2003). Considerando os adequados fatores de correção a técnica da água duplamente marcada possibilita o único método prático para estimar o gasto de energia de animais em vida livre por longos períodos de tempo.

Apesar de ser considerado o método mais preciso para determinação direta dos gastos de energia em animais em vida livre em seus ambientes naturais (Parker, 2003), este método foi utilizado em apenas 3 espécies de cervídeos: Rangifer tarandus (Fancy et al., 1986, Gotaas et al., 2000b), Odocoileus hemionus (Parker et al., 1999) e Cervus elaphus (Haggarty et al., 1998).

Este método tem sido amplamente utilizado em estudos de metabolismo energético tanto em humanos (Schoeller \& VanSanten, 1982; Schoeller et al. 1986) como em bovinos no Brasil (Lanna, 1985; Leme, 1994) e espécies de animais domésticos de pequeno porte semelhante aos utilizados neste projeto (Midwood et al., 1994; Speakman e Racey, 1988 e Torien et al., 1999). Este método foi validado em ruminantes por Fancy et al. (1986).

\subsection{Técnica de Isótopos de Carbono}

O principal método utilizado para estimar a composição da ingesta em ruminantes é baseado na análise botânica ou microhistologia, do conteúdo ruminal e das fezes. O processo de fermentação no rúmen durante a digestão e a diversidade de plantas ingeridas pelos ruminantes torna difícil determinar uma relação direta entre cada componente da dieta e sua contribuição para o atendimento às exigências nutricionais. Alterações nos níveis de fibra da dieta e conseqüentemente na relação entre carboidratos estruturais e conteúdos celulares afetam diretamente a população microbiana do rúmen, alterando a quantidade e a qualidade dos produtos finais da fermentação. O aumento no consumo de forragens fibrosas normalmente causa depressão da digestibilidade enquanto o consumo de porções suculentas como brotos, flores e frutos apresentam maior digestibilidade. Estas alterações de digestibilidade afetam as análises botânicas do 
conteúdo ruminal e das fezes com o objetivo de caracterização da dieta, comprometendo parcialmente a precisão do método.

Os isótopos estáveis funcionam como marcadores naturais que fornecem informações sobre diferentes dietas e locais de alimentação. Animais forrageando e se movendo sobre áreas diferentes carregam consigo sinais isotópicos distintos das espécies e áreas previamente pastejadas.

A estimativa de composição botânica da dieta de ruminantes utilizando a relação entre os isótopos de carbono ${ }^{13} \mathrm{C}$ e ${ }^{12} \mathrm{C}$ foi inicialmente utilizada por Minson et al. (1975) que demonstraram que os sinais isotópicos $\left(\delta^{13} \mathrm{C}\right)$ do leite o dos pêlos de vacas pastando eram determinados pelo tipo de planta $\left(\mathrm{C}_{3}\right.$ ou $\left.\mathrm{C}_{4}\right)$ consumido. Este método é baseado na diferença que existe na concentração de ${ }^{13} \mathrm{C}$ entre plantas com ciclo fotossintético $\mathrm{C}_{3}$ $\left(\delta^{13} \mathrm{C} \approx-28\right)$ e $\mathrm{C}_{4}\left(\delta^{13} \mathrm{C} \approx-11\right)$.

Jones et al. (1979) determinaram as regressões entre os sinais isotópicos do ${ }^{13} \mathrm{C}$ de fezes e plantas oferecidas para coelhos, caprinos, ovinos e bovinos. Esses autores também identificaram que existe pequena contaminação endógena nas fezes, oriunda de tecidos marcados com sinais isotópicos de plantas previamente ingeridas, especialmente se elas pertencerem ao grupo de ciclo fotossintético $\mathrm{C}_{3}$, cujo sinal é mais negativo. Em bovinos que tiveram dietas alteradas de leguminosas para gramíneas o novo equilíbrio foi atingido após 6 dias de ingestão exclusiva da nova dieta.

No Brasil, Lourenço et al. (1984) estudaram os efeitos de dietas exclusivas de gramíneas ou consorciadas com leguminosas sobre os sinais isotópicos nas fezes, leite e sangue de vacas e identificaram diferentes níveis de consumo de soja perene (Neonotonia wightii) em diferentes épocas do ano.

Os sinais isotópicos das plantas $\mathrm{C}_{3}$ e $\mathrm{C}_{4}$ também podem ser utilizados em estudos de digestibilidade de diferentes dietas, com níveis distintos de mistura entre gramíneas e leguminosas, em cativeiro (Bruckental, et al., 1985) ou condições controladas de pastejo. Em ambientes naturais onde a diversidade botânica é elevada esta metodologia não seria adequada para estudos de digestibilidade. 
A principal desvantagem deste método é que não é possível distinguir o sinal isotópico do ${ }^{13} \mathrm{C}$ de diferentes espécies de ciclo $\mathrm{C}_{3}$ ou $\mathrm{C}_{4}$, impossibilitando a segregação precisa das plantas ingeridas.

\subsection{Técnica de n-alcanos}

Um "marcador" da digestão permite estimar indiretamente o consumo e a digestibilidade de um alimento. O "marcador ideal" deve ser indigestível, completamente recuperado nas fezes, comportar-se no trato digestivo exatamente como a média da digesta (e.g. mesma taxa de passagem), não prejudicar a digestão ou o animal e ser facilmente analisado no laboratório tanto nas fezes como no alimento. Quando este marcador já esta presente na composição do alimento, é chamado de "marcador natural" ou "marcador interno". Nas ceras das plantas pode-se encontrar marcadores naturais que tem grande potencial de utilização para estudos com ruminantes e outros herbívoros selvagens. Marcadores não naturais ou marcadores externos podem ser utilizados principalmente para determinação de digestibilidade e consumo (Schneider, 1975).

Nas ceras das plantas encontram-se substâncias que podem ser usadas como marcadores, tais como alguns ácidos graxos de cadeia longa (Grace \& Body, 1981) e hidrocarbonetos alifáticos saturados, os n-alcanos (Mayes \& Lamb, 1984). Os n-alcanos são compostos orgânicos que possuem em sua estrutura átomos de carbono e hidrogênio. Quando apresentam mais de 20 átomos de carbono em sua cadeia podem ser classificados como parafinas (Morrison \& Boyd, 1972).

Significativos avanços no estudo dos alcanos ocorreram com o desenvolvimento de técnicas de cromatografia gasosa e análise do espectro infravermelho, que contribuíram, para identificar com mais exatidão as diferentes moléculas. Usando estes componentes indigestíveis das plantas, têm se várias vantagens sobre outros métodos para determinar o consumo e a digestibilidade em ruminantes (Mayes et al., 1986).

$\mathrm{Na}$ natureza os alcanos predominantes nas plantas se encontram entre o $\mathrm{C}_{25}$ a $\mathrm{C}_{35}$ (Hawke et al., 1973). Em estudos recentes Oliveira et al., (1997) encontraram em várias espécies de gramíneas n-alcanos de $\mathrm{C}_{20}$ a $\mathrm{C}_{37}$, sendo os $\mathrm{C}_{29}, \mathrm{C}_{31}$ e $\mathrm{C}_{33}$ mais abundantes 
do que os outros. Esses estudos demonstraram predominância dos alcanos ímpares sobre os pares. Em 1965, Oró et al., verificaram a similaridade dos alcanos encontrados nas fezes de bovinos com os da forragem consumida pelos animais. Nas análises das fezes, esses autores encontraram alcanos de $C_{18}$ a $C_{35}$ com predominância do $C_{29}, C_{31}$ e $C_{33}$, e verificaram que quanto maior a cadeia de carbono nos alcanos, mais completa era a recuperação destes nas fezes. Notaram também a grande similaridade entre o perfil de alcanos encontrados nas folhas e aqueles observados nas fezes. Isto seria explicado pelo fato de que a fração de folhas ingeridas era a mais consumida pelos animais. A partir disto, começaram estudos sobre a eficiência de se usar os alcanos para se estimar o consumo e a digestibilidade em ruminantes.

A utilização dos alcanos como indicadores internos de digestibilidade, têm uma relação direta com o número de carbonos encontrados em sua cadeia, e quanto maior a cadeia, maior a recuperação destes (menor a perda no trato digestivo). Mayes \& Lamb (1984), trabalhando com ovinos, recebendo dietas de azevém e trevo branco, sugeriram que alcanos de cadeia longa poderiam ser usados para determinar a digestibilidade das forragens e concluíram que quanto maior a cadeia de carbono dos alcanos, maior a sua recuperação nas fezes. A utilização dos alcanos como indicadores para estimar o consumo de forragens, requer o uso da técnica do duplo-alcano, ou seja, usa-se um alcano de cadeia ímpar, natural da forragem e um alcano de cadeia par, sintético fornecido aos animais (Gedir \& Hudson, 2000). Dotriacontano - $\mathrm{C}_{32}$ e hexatriacontano $\mathrm{C}_{36}$ são marcadores externos ideais e podem ser facilmente obtidos na forma pura e são encontrados relativamente em pequenas concentrações nas plantas. Uma única análise cromatográfica permite observar as concentrações nas fezes e alimentos de todos os diferentes alcanos. Portanto, esta técnica de marcadores tem sido alvo de grande interesse para muitos ruminantes domésticos.

Muitos métodos de marcadores requerem o seu fornecimento várias vezes ao dia, através de cápsulas de gelatina ou "pellets" de papel, que resultam num trabalho intensivo e podem causar uma variação diurna da liberação dos marcadores, bem como interferir no comportamento ingestivo dos animais (Dove \& Mayes, 1991). Este não é o caso dos n-alcanos fornecidos via cápsulas. 
Trabalhando com girafas em cativeiro, Hatt et al., (1998) concluíram que o método de alcanos tem a vantagem de ser não invasivo e foi válido para o estudo da cinética da digesta em girafas e, possivelmente, poderia ser com outros herbívoros não domésticos. Os resultados obtidos por esses autores para as estimativas da ingestão e da digestibilidade foram muito promissores, ainda que não totalmente similares com as medidas diretas. Ainda neste mesmo trabalho, as variações diurnas na concentração de alcanos nas fezes foram um problema devido ao uso de n-alcanos de cadeia par dosados com "pellets" de papel que deveriam ter sido administrados mais vezes durante o dia. Os referidos autores, observaram ainda que o uso de alimentos com baixa concentração de alcanos ( $<10 \mathrm{mg} / \mathrm{Kg} \mathrm{MS})$ não são adequados para estudos da composição da dieta. Com a liberação intra-ruminal dos marcadores através de cápsulas de liberação lenta é possível eliminar a necessidade de ficar dosando os animais constantemente, fato que resultaria em estresse, particularmente quando se trabalha com ruminantes selvagens.

A técnica de n-alcanos para estimativa da composição botânica da dieta de herbívoros vem sendo recentemente utilizada em estudos nutricionais de animais domésticos (Valiente et al., 2003; Nia \& Wittenberg, 2002; Oliveira, et al., 2004) e selvagens (Smith et al., 2001).

Segundo Dove e Moore (1996) para uma maior sensibilidade na estimativa da composição botânica da dieta, o conteúdo total de n-alcanos das diferentes espécies vegetais deve ser semelhante mas os perfis devem ser bastante diferentes. O número máximo de espécies que poderia ser separado é limitado ao número de n-alcanos usados nas equações de estimativa.

Smith et al. (2001) compararam 40 espécies nativas do sudoeste da África em relação a seus perfis de n-alcanos com o objetivo de identificar as diferenças entre espécies. Esses autores afirmaram que, embora houvesse diferença estatística entre os alcanos ímpares das diferentes espécies, não seria possível, numa amostra composta ou de fezes, distinguir entre espécies, principalmente devido à similaridade entre os perfis de n-alcanos.

O uso de n-alcanos para estimar a composição botânica de dietas depende da contribuição relativa das diferentes espécies vegetais para o perfil de alcanos das fezes 
(Dove et al., 1996). Se diferentes plantas têm perfis de n-alcanos semelhantes é difícil distinguir nas fezes as espécies ingeridas (Smith et al., 2001). Espécies com altas concentrações de n-alcanos têm uma influência desproporcional no perfil de alcanos das fezes pois ocultam espécies com baixas concentrações (Mayes e Dove, 2000).

Uma alternativa para distinguir diferentes plantas com perfis semelhantes é o agrupamento de diferentes espécies com perfis semelhantes, reduzindo entretanto o número de grupos a serem discriminados (Mayes e Dove, 2000). Outra possibilidade é combinar a técnica de n-alcanos com outros métodos como microhistologia, em busca de restringir o número de espécies a serem incluídas nos cálculos (Dove et al. 1996). Nesse experimento as espécies incluídas nos cálculos foram aquelas efetivamente ingeridas pelos animais nos diferentes períodos, cujas partes vegetais foram coletadas acompanhando-se os indivíduos e simulando o pastejo.

Smith et al. (2001) demonstraram que diferentes partes da mesma espécie têm perfis de alcanos significativamente diferentes e devem ser consideradas separadamente nos cálculos de composição da dieta.

Valiente et al. (2003) utilizaram com sucesso a técnica de n-alcanos para determinar as frações de diferentes partes de aveia (Avena sativa), grãos, folhas e hastes, fornecidas a ovelhas na forma de ração misturada com diferentes proporções de grãos e forragem verde. As diferenças nos perfis de alcanos das diferentes frações da mesma espécie vegetal permitiram a precisa identificação das proporções constituintes das dietas.

Boadi et al. (2002), estudando o perfil de n-alcanos de espécies nativas e cultivadas em diferentes regiões do Canadá determinaram que não houve efeito significativo da localidade e da cultivar nas concentrações de n-alcanos das espécies. Dove et al. (1996) identificaram que as diferenças entre espécies contribuem muito mais para a variação de concentração dos n-alcanos do que diferentes locais ou épocas do ano. As diferenças nas concentrações dos alcanos da mesma espécie em locais diferentes podem ser atribuídas a diferentes condições climáticas, ambientais e de solo (Boadi et al., 2002). 
Os estudos deste projeto procuraram basicamente usar as metodologias de nalcanos descritas por Mayes \& Dove (2000), especificamente para determinar a digestibilidade e os tipos de alimentos selecionados pelo animal. 


\section{DETERMINAÇÃO DA DEMANDA DE ENERGIA DO VEADO- CATINGUEIRO (MAZAMA GOUAZOUBIRA) EM CATIVEIRO ATRAVÉS DO MÉTODO DA ÁGUA DUPLAMENTE MARCADA}

Resumo

Existem poucas informações sobre exigências de energia de cervídeos brasileiros, dificultando o sucesso de manejo e reprodução em cativeiro. O objetivo deste experimento foi estudar as exigências nutricionais do veado catingueiro (Mazama gouazoubira) em cativeiro. A determinação das exigências de energia para mantença utilizou 8 veados-catingueiro de ambos os sexos em cativeiro e foi desenvolvida através de dois métodos: a)equilíbrio de peso e b)água duplamente marcada $\left({ }^{2} \mathrm{H}_{2}{ }^{18 \mathrm{o}}\right)$. Os animais foram dosados com água duplamente marcada $(111,8$ $\mathrm{mg} / \mathrm{kgPV}$ para ${ }^{2} \mathrm{H}_{2} \mathrm{O}$ e $163,1 \mathrm{mg} / \mathrm{kgPV}$ para $\mathrm{H}_{2}{ }^{18} \mathrm{O}$ ) e amostras de sangue foram coletadas em intervalos de 3 dias, até que 3 ou 4 meias-vidas dos isótopos tenham decorrido (atingindo o limite de detecção em aproximadamente 30 dias após a dosificação). As curvas de desaparecimento dos isótopos em função do tempo foram utilizadas para calcular o "turnover" de $\mathrm{CO}_{2}$ e $\mathrm{H}_{2} \mathrm{O}$. Os resultados obtidos pelos dois métodos foram semelhantes $\left(111,4\right.$ e $\left.112,0 \mathrm{kcal} / \mathrm{kg}^{.75} . \mathrm{d}\right)$ comprovando que a técnica da água duplamente marcada pode ser utilizada em estudos nutricionais de cervídeos. Informações de doses $(\mathrm{mg} / \mathrm{kgPV})$ e intervalo máximo entre aplicação e coleta de sangue (30 dias), permitem o uso desta metodologia em estudos futuros em vida livre. Este trabalho determinou as exigências de energia do veado-catingueiro em cativeiro e validou o uso de uma técnica indireta para futuros estudos em vida livre. 
Summary

There are limited data on energy requirements of brazilian cervids. Thus, it is difficult to succeed in their management and reproduction in captivity. The objective of this experiment was to study the nutritional requirements of the grey-brocket deer (Mazama gouazoubira) in captivity. The determination of energy requirements for maintenance used 8 gray-brocket deer of both sexes in captivity and was carried through two methods: a)weight equilibrium and b)double-labeled water $\left({ }^{2} \mathrm{H}_{2}{ }^{18} \mathrm{O}\right)$. The animals were dosed with double-labeled water $\left(111.8 \mathrm{mg} / \mathrm{kgBW}\right.$ for ${ }^{2} \mathrm{H}_{2} \mathrm{O}$ and $163.1 \mathrm{mg} / \mathrm{kgBW}$ for $\mathrm{H}_{2}{ }^{18} \mathrm{O}$ ) and blood samples were collected with 3 days interval, until 3 or 4 half lives of isotopes had occurred (reached limit of detection at approximately 30 days after the dosage). The curves of isotopes disappearance as a function of time were used to calculate the turnover of $\mathrm{CO}_{2}$ and $\mathrm{H}_{2} \mathrm{O}$. The results obtained from the two methods were similar (111.4 and $\left.112.0 \mathrm{kcal} / \mathrm{kg}^{.75} . \mathrm{d}\right)$ proving the double-labeled water technique may be used in nutritional studies of cervids. Information on doses $(\mathrm{mg} / \mathrm{kgBW})$ and maximum interval between injection and blood collection (30days), allow the use of this methodology in future studies with free ranging deer. This work determined the requirements of energy of grey-brocket deer in captivity and validated the use of one indirect technique for use in free ranging animals.

\subsection{Introdução}

$\mathrm{O}$ experimento em cativeiro foi conduzido na FCAV/UNESP, Jaboticabal, em duas etapas: a primeira nos meses de setembro, outubro e novembro de 2001 e a segunda em janeiro e fevereiro de 2004. Na primeira etapa foram utilizados 8 veados-catingueiro (Mazama gouazoubira) adultos de ambos os sexos (4 machos e 4 fêmeas) pertencentes ao rebanho em cativeiro experimental da UNESPJaboticabal. Nenhum dos machos estava sendo utilizado para reprodução e nenhuma das fêmeas estava gestante ou lactante. Desta forma os animais estariam utilizando energia apenas para execução das funções de manutenção como manutenção dos 
gradientes das membranas, síntese de macromoléculas, manutenção da homotermia e atividade física mínima necessária à sobrevivência - busca de alimento e água.

Por serem animais sensíveis ao manejo, as atividades experimentais do $1^{\circ}$ ensaio foram conduzidas de forma a não estressar os animais, fato que alteraria seu aporte e demanda de energia. As atividades de manejo mais críticas, como pesagens, foram sempre acompanhadas por um técnico responsável e experiente do Setor de Animais Silvestres da FCAV/UNESP. Os animais mostraram-se bastante dóceis durante a condução do experimento, se acostumando com nossa presença diária no fornecimento de água e ração.

A segunda etapa do Ensaio I, o experimento com água duplamente marcada, foi realizada na mesma estação do experimento inicial mas em virtude de atrasos na importação do material só foi possível iniciá-la em janeiro de 2004, dois meses após o previsto mas ainda sob condições climáticas semelhantes de temperatura e umidade relativa do ar.

O rebanho experimental da FCAV/UNESP foi parcialmente alterado neste intervalo e estavam à disposição para a segunda etapa 9 animais, 2 machos e 7 fêmeas, sendo que 6 destes participaram do experimento inicial. As baias utilizadas foram as mesmas de $8 \mathrm{~m}^{2}$ do experimento inicial.

Apesar dos animais mostrarem certa tolerância ao manejo intensivo do cativeiro, o ensaio com água duplamente marcada demandaria contenção manual e muitas coletas consecutivas de sangue que poderiam estressar os animais. Para minimizar o estresse da contenção tanto no momento da aplicação da água duplamente marcada quanto nas coletas de sangue novamente houve acompanhamento de um técnico experiente, responsável pelo Setor de Animais Silvestres da FCAV/UNESP.

O objetivo deste experimento foi testar a técnica de água duplamente marcada em pequenos cervídeos, obtendo informações importante e essenciais para um futuro estudo em vida livre com cervídeos de médio porte. 


\subsection{Material e Métodos}

Não havia na literatura nenhuma pesquisa de exigências nutricionais para esta espécie de cervídeo brasileiro. Para balancearmos uma ração que satisfizesse as exigências de manutenção destes animais utilizamos dados obtidos para outras espécies de cervídeos (Brown, 1995; Haigh \& Hudson, 1993; Holter et al., 1979; Ulrey et al., 1967, 1970; Van der Eems et al.,1988) e de ruminantes domésticos de pequeno porte: ovinos e caprinos (Nutrient requirement of sheep, 1985; Nutrient Requirements of Goats: Angora, Dairy, and Meat Goats in Temperate and Tropical Countries, 1981).

A ração experimental foi formulada com a seguinte composição (Tabelas $1 \mathrm{e}$ 2):

Tabela 1. Ingredientes da dieta experimental

\begin{tabular}{lc}
\hline Ingredientes: & $(\%)$ \\
\hline Feno de Alfafa & 63,9 \\
Amido de Milho & 16,9 \\
Levedura desidratada & 14,7 \\
Melaço & 2,5 \\
Suplem. Mineral & 1,0 \\
Suplem. Vitamínico & 0,5 \\
Cloreto de Sódio & 0,5 \\
\hline Tabela 2. Composição nutricional da dieta \\
\hline Composição da dieta: & $(\%)$ \\
\hline Matéria Seca & 87,9 \\
Matéria Orgânica & 90,8 \\
Matéria Mineral & 9,2 \\
Proteína Bruta & 19,4 \\
Extrato Etéreo & 1,2 \\
FDN & 29,5 \\
Hemicelulose & 6,0 \\
Celulose & 17,7 \\
Lignina & 5,1 \\
Energia Bruta (Mcal/kg) & 4,25 \\
\hline
\end{tabular}


A ração deveria conter uma única fonte de fibra vegetal para evitar diferentes origens dos n-alcanos presentes na dieta total. Por este motivo optamos em utilizar amido de milho puro como fonte de energia e levedura desidratada como fonte de proteína.

Uma batida inicial de ração foi feita enquanto realizaram-se as análises de laboratório para confirmar a composição nutricional dos ingredientes indicada nos rótulos dos produtos. Foram avaliados os teores de Matéria Seca (MS), Matéria Mineral (MM), Proteína Bruta (PB), Energia Bruta (EB), Extrato Etéreo (EE), Fibra em detergente neutro (FDN), Fibra em detergente ácido (FDA) segundo metodologias descritas por Van Soest (1994). Isto foi necessário para evitar desbalanceamento da ração experimental devido à imprecisões nas informações dos fornecedores e fabricantes. Depois de verificada a composição real dos ingredientes, foram ajustadas as percentagens dos mesmos para a mistura da ração experimental. A ração inicial foi utilizada nas duas primeiras semanas de adaptação enquanto a ração experimental foi utilizada no período final de adaptação e durante todo período experimental.

Os animais foram alimentados à vontade com esta ração por 54 dias após um período de adaptação de 25 dias. Este período de adaptação foi essencial para permitir que os animais passassem a ingerir apenas a ração experimental, sem outra fonte de capim, feno ou ração de eqüinos, que normalmente constituía sua dieta. A quantidade oferecida foi ajustada a cada dois dias de forma a manter uma sobra de $5 \%$ do oferecido, reduzindo o desperdício de ração. Os animais tinham acesso irrestrito à água.

Diariamente foram determinados os valores de oferta e sobra de água e ração. Os consumos diários foram determinados diminuindo-se a quantidade de sobra do total oferecido. Os volumes de água (oferta e sobra) foram determinados com proveta plástica de $1.000 \mathrm{~mL}$ e os pesos da ração (oferta e sobra) em balança de precisão. As amostras de alimento oferecido, sobras e fezes também foram analisadas para as variáveis descritas anteriormente. Para a determinação precisa do 
consumo de água foi considerada a evaporação do período, medida através de um bebedouro referência.

Para determinação da digestibilidade da dieta elaborada foi conduzido um experimento que comparou valores obtidos através de coleta total de fezes e através de n-alcanos como indicadores (Barbosa, 2003). As coletas de fezes foram realizadas durante 24 horas por dia, em 5 dias consecutivos, para determinação da digestibilidade da ração através da coleta total. As baias foram vistoriadas a cada 30 minutos para verificar se os animais haviam defecado, pois as fezes deveriam ser coletadas o mais breve possível para evitar pisoteio e contaminação com urina. Nestes 5 dias de coleta as baias ficaram sem cama (feno de coast-cross) para evitar ingestão e contaminação de n-alcanos externos à dieta experimental. A digestibilidade estimada foi obtida através do método de n-alcanos segundo metodologia descrita por Oliveira (2004).

Por estarem em condição de cativeiro e alojados em baias individuais de $8 \mathrm{~m}^{2}$ julgamos interessante obter alguns parâmetros climáticos, principalmente temperatura e umidade relativa do ar e verificar sua relação com o consumo de água e alimento. Estes parâmetros foram determinados diariamente às 15:00hs, registrando os valores máximos e mínimos das últimas 24 horas, com o auxílio de um termohigrômetro digital. Foram realizadas regressões simples entre consumo de água e ração com URmed, URmax, URmin, Tmed, Tmax e Tmin utilizando-se o procedimento Regr do SAS (SAS, 1999).

Para verificar a manutenção dos pesos individuais, foram realizadas pesagens a cada 21 dias. Os animais eram direcionados a uma caixa de madeira com peso previamente determinado e posteriormente pesados numa balança eletrônica. Por ser um momento delicado buscamos sempre realizá-las no período da manhã, com temperatura mais amena e sob supervisão do responsável técnico do Setor de Animais Silvestres da FCAV/UNESP. O escore corporal foi observado visualmente a cada 7 dias, durante os 54 dias de experimento para verificação da manutenção da composição corporal, verificando se o animal estava ganhando ou perdendo massa muscular e/ou gordura. 
Os resultados de exigências de energia metabolizável obtidos no ensaio de alimentação controlada por longo período de tempo com manutenção do peso e da condição corporal dos animais foram comparados com os resultados obtidos através do método da água duplamente marcada.

Como não há na literatura nenhum trabalho realizado utilizando-se a metodologia da água duplamente marcada com esta espécie (Mazama gouazoubira) buscamos comparações com ruminantes domésticos (ovinos) e outros cervídeos de espécies diferentes, chegando aos valores de $150 \mathrm{mg} / \mathrm{kg}$ de peso vivo de $\mathrm{H}_{2}{ }^{18} \mathrm{O}$ e $100 \mathrm{mg} / \mathrm{kgPV}$ de ${ }^{2} \mathrm{H}_{2} \mathrm{O}$ a serem aplicados nos animais. A quantidade de $\mathrm{H}_{2}{ }^{18} \mathrm{O}$ aplicada, material mais caro, deveria ser maior pois o oxigênio marcado é perdido tanto na forma de $\mathrm{CO}_{2}$ quanto de $\mathrm{H}_{2} \mathrm{O}$, premissa básica da metodologia da água duplamente marcada.

No experimento inicial com n-alcanos, foram realizadas pesagens dos animais e estas foram comparadas com pesagens posteriores para determinar a quantidade de água duplamente marcada a ser aplicada por animal. De forma geral os pesos foram mantidos pois os machos não estavam reproduzindo, as fêmeas não estavam prenhes nem lactando e o manejo se manteve bastante homogêneo desde o experimento inicial. O experimento com água duplamente marcada foi idealizado para ser executado simultaneamente ao experimento com n-alcanos. Devido a dificuldades para aquisição deste caro produto, o experimento com a água duplamente marcada foi realizado posteriormente, dois anos depois do experimento inicial na mesma época do ano.

As coletas de sangue foram programadas de forma a obter uma curva de desaparecimento dos isótopos bastante clara e precisa, identificando o acentuado aumento na concentração dos isótopos no momento inicial e sua queda gradual com o desaparecimento. Por este motivo foram realizadas mais coletas nos primeiros dias após a aplicação conforme Figura 2. 


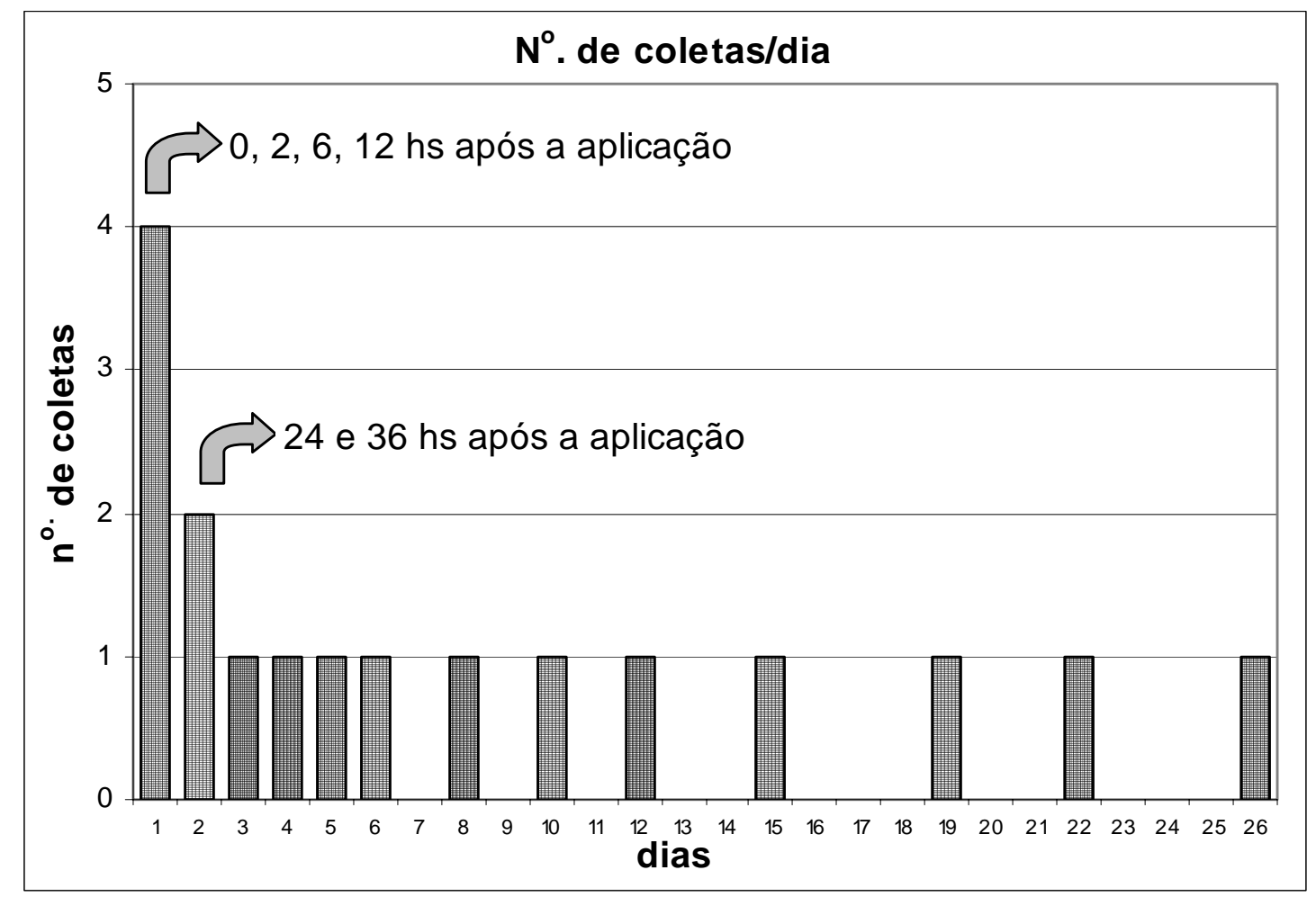

Figura 2 - Cronograma de coleta de sangue

Para controlar de forma bastante precisa a quantidade de água aplicada por animal as seringas foram pesadas vazias e cheias com água marcada até o volume aproximado desejado. Foram utilizadas seringas independentes para aplicação da $\mathrm{H}_{2}{ }^{18} \mathrm{O}$ e da ${ }^{2} \mathrm{H}_{2} \mathrm{O}$ para maior controle da quantidade injetada. As aplicações foram feitas por injeção direta em na veia jugular com o auxílio de um catéter. Para evitar que parte da água marcada ficasse retida no interior do catéter foi feita lavagem da seringa sugando e reinjetando sangue por três vezes. Ao final deste processo o restante do catéter foi lavado injetando-se mais $2 \mathrm{~mL}$ de soro fisiológico.

Antes da aplicação da água marcada foi retirada uma amostra de sangue para determinação da concentração basal natural do ${ }^{18} \mathrm{O}$ e do ${ }^{2} \mathrm{H}$. As coletas subseqüentes foram estipuladas com base em curvas de desaparecimento destes isótopos encontradas na literatura (Fancy et al, 1996; Haggarty, 1991; Midwood et al, 1994). As coletas de sangue foram feitas utilizando-se tubos de $9 \mathrm{ml}$ com vácuo (Vacuette) sem anti-coagulante pois as amostras permaneceriam congeladas até o momento da 
destilação da água do sangue. As análises das concentrações dos isótopos de hidrogênio e oxigênio foram realizadas na ordem inversa da seqüência de coletas. Isto se fez necessário porque as primeiras amostras de sangue eram muito ricas nos isótopos e poderiam "enriquecer" a coluna do cromatógrafo, superestimando a concentração dos isótopos nas amostras finais menos concentradas.

A partir das curvas de desaparecimento do ${ }^{18} \mathrm{O}$ e do ${ }^{2} \mathrm{H}$ calculamos a produção de $\mathrm{CO}_{2}$ pois a curva do ${ }^{2} \mathrm{H}$ representa a perda de $\mathrm{H}$ através da $\mathrm{H}_{2} \mathrm{O}$ e a curva do ${ }^{18} \mathrm{O}$ representa a perda de $\mathrm{O}$ através da $\mathrm{H}_{2} \mathrm{O}$ e $\mathrm{CO}_{2}$.

A produção de calor, equivalente à exigência de energia metabolizável para mantença dos animais foi calculada à partir da produção de $\mathrm{CO}_{2}$, utilizando-se a equação de Brouwer (1965), descontando $8 \%$ de perda de ${ }^{2} \mathrm{H}$ no Metano e $1 \%$ na urina (Midwood et al., 1989 e 1993). A perda nas fezes não foi considerada significativa. Como os animais não estavam crescendo nem engordando as perdas hidrogênio seqüestrado no tecido adiposo também foram desconsideradas (Midwood et al., 1993). O quociente respiratório foi considerado 0,80 (Blaxter, 1964).

$$
\mathrm{PC}(\mathrm{kcal})=3,866 * \mathrm{rCO}_{2} / \mathrm{QR}+1,2 * \mathrm{rCO}_{2}-\left(0,518 * \mathrm{rCH}_{4}+1,431 * \mathrm{~N}\right) .
$$

Sendo:

PC : Produção de Calor (kcal)

QR : Quociente Respiratório

$\mathrm{rCO}_{2}$ : Produção de $\mathrm{CO}_{2}(\mathrm{~L})$

$\mathrm{rCH}_{4}$ : Produção de $\mathrm{CH}_{4}(\mathrm{~L})$

$\mathrm{N}$ : Nitrogênio na urina (L) 


\subsection{Resultados e Discussão}

Os resultados dos efeitos das condições climáticas no cativeiro sobre os consumos de água e ração estão descritos abaixo. Os valores médios dos parâmetros climáticos do período experimental estão na Tabela 3:

\begin{tabular}{|c|c|c|}
\hline Parâmetro & Média & $\begin{array}{c}\text { Desvio } \\
\text { Padrão } \\
\end{array}$ \\
\hline $\mathrm{T} \mathrm{14:00({ } ^ { \circ } \mathrm { C } )}$ & 32,0 & 4,0 \\
\hline $\mathrm{T}$ máx $\quad\left({ }^{\circ} \mathrm{C}\right)$ & 34,4 & 3,0 \\
\hline $\mathrm{T} \min \quad\left({ }^{\circ} \mathrm{C}\right)$ & 19,6 & 2,1 \\
\hline $\mathrm{T}$ méd $\quad\left({ }^{\circ} \mathrm{C}\right)$ & 27,0 & 1,8 \\
\hline UR 14:00 (\%) & 44,4 & 19,9 \\
\hline UR máx $\quad(\%)$ & 95,0 & 6,1 \\
\hline UR min $\quad(\%)$ & 32,6 & 10,5 \\
\hline UR méd $\quad(\%)$ & 63,8 & 7,5 \\
\hline
\end{tabular}

T: Temperatura (oC), UR Umidade relativa (5)

Seria esperado que o consumo de água fosse maior nos dias mais quentes e de menor umidade relativa do ar. Analogamente o consumo de ração poderia ser deprimido nos dias mais quentes e úmidos. Estas relações não foram observadas através de regressões lineares $(\mathrm{P}>0,01)$ mesmo tendo sido observadas amplas variações de temperatura $\left(14,3\right.$ a $\left.38,2{ }^{\circ} \mathrm{C}\right)$ e umidade relativa do ar $(17$ a $100 \%)$.

Os resultados médios dos consumos de água e ração no período experimental estão na Tabela 4. 
Tabela 4. Médias dos consumos de ração e água no período experimental

\begin{tabular}{|c|c|c|c|c|}
\hline Animal & $\begin{array}{c}\text { Ração } \\
\left(\mathrm{g} \mathrm{MS} / \mathrm{kg}^{.75} . \mathrm{d}\right)\end{array}$ & $\begin{array}{l}\text { Desvio } \\
\text { Padrão }\end{array}$ & $\begin{array}{c}\text { Água } \\
\left(\mathrm{mL} / \mathrm{kg}^{.75} . \mathrm{d}\right)\end{array}$ & $\begin{array}{l}\text { Desvio } \\
\text { Padrão }\end{array}$ \\
\hline 1 & 45,5 & 8,4 & 134,2 & 29,3 \\
\hline 2 & 54,4 & 4,9 & 150,0 & 22,3 \\
\hline 3 & 44,7 & 7,3 & 106,7 & 19,3 \\
\hline 4 & 57,1 & 5,3 & 186,2 & 29,0 \\
\hline 5 & 49,4 & 7,7 & 144,8 & 22,0 \\
\hline 6 & 49,9 & 5,3 & 134,0 & 19,1 \\
\hline 7 & 54,2 & 8,5 & 160,4 & 28,6 \\
\hline 8 & 48,5 & 4,8 & 127,7 & 25,0 \\
\hline Média & 50,7 & 3,5 & 143,5 & 12,2 \\
\hline
\end{tabular}

Os valores diários dos parâmetros climáticos e de consumo estão apresentados graficamente na Figura 3.

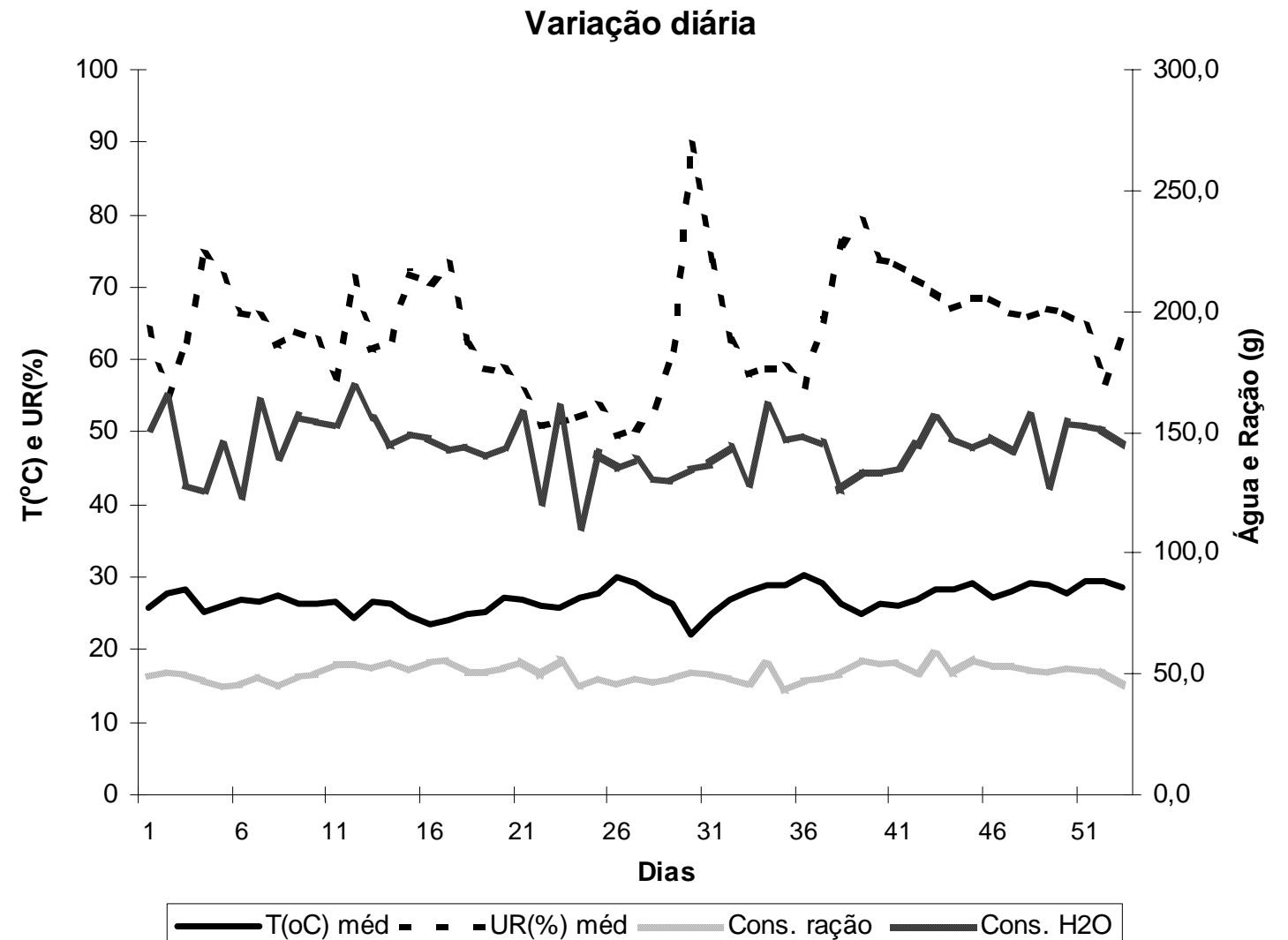

Figura 3 - Valores diários dos parâmetros climáticos e de consumo 
Podemos observar que as variações diárias de umidade relativa (\%) e de consumo de água $(\mathrm{mL} / \mathrm{d})$ foram mais acentuadas. Nenhuma relação entre parâmetros climáticos e consumo de água ou ração foi observada. Utilizando-se o procedimento Regr do SAS (SAS, 1999), determinamos que nenhuma regressão foi significativa $(\mathrm{P}>0,05)$. Realizamos também regressões múltiplas entre consumo de água e Tmax e URmin mas nenhuma correlação significativa foi observada $(\mathrm{P}>0,05)$.

As regressões simples obtidas estão graficamente representadas nas Figuras 4 e 5 .

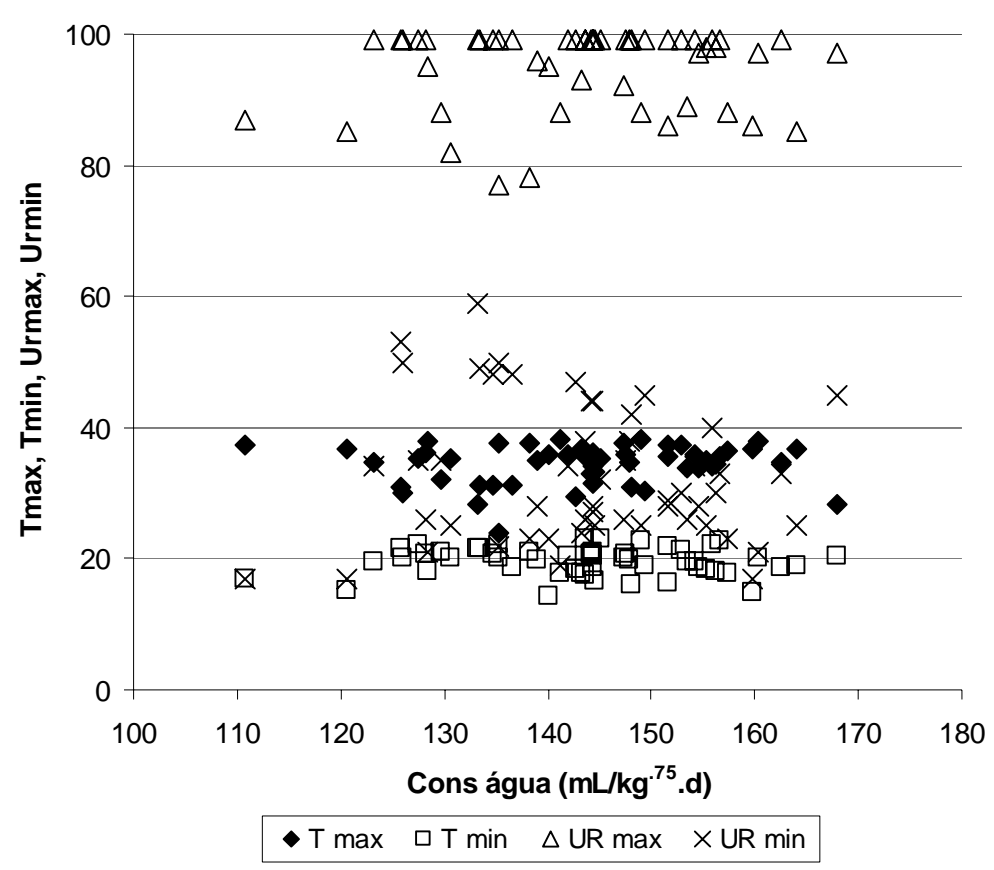

Figura 4 - Consumo de água (mL/dia) relacionado aos parâmetros climáticos: Tmax $\left({ }^{\circ} \mathrm{C}\right)$, $\operatorname{Tmin}\left({ }^{\circ} \mathrm{C}\right)$, URmax $(\%), \operatorname{URmin}(\%)$ 


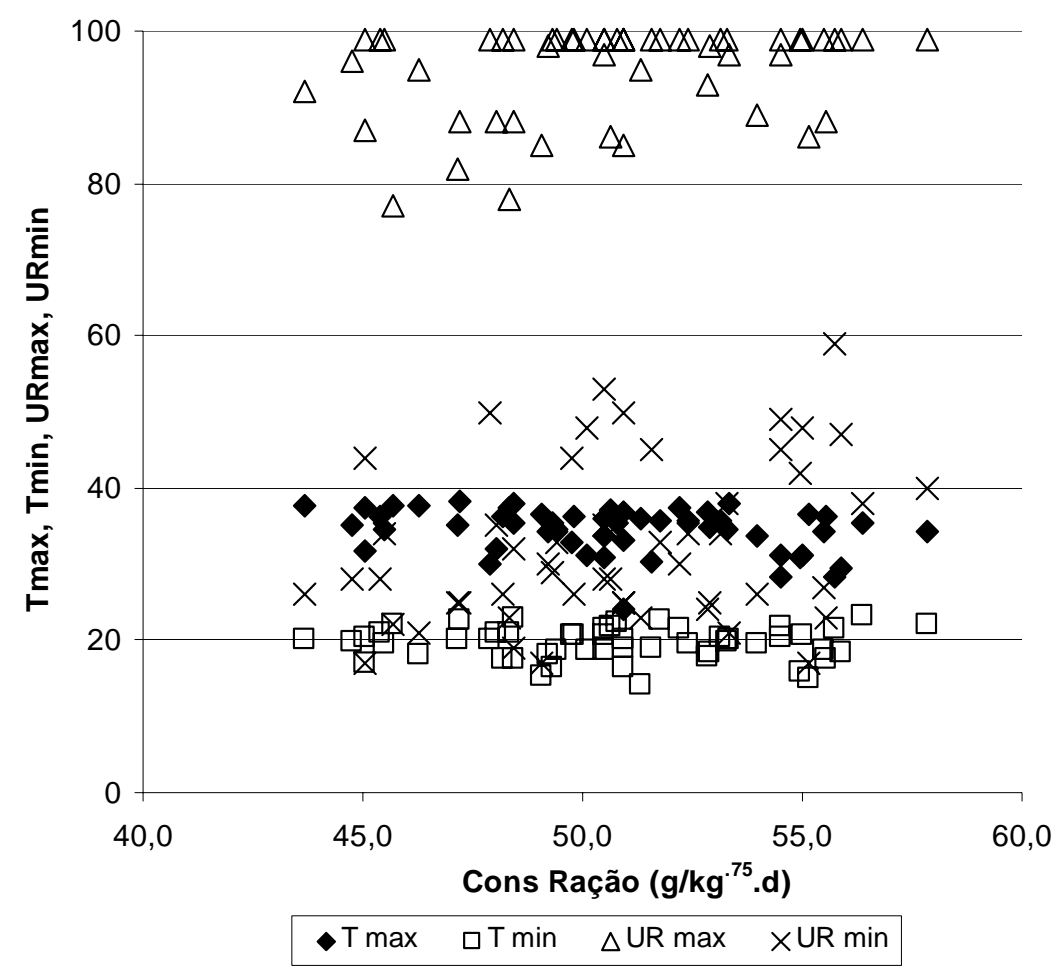

Figura 5 - Consumo de ração (g/dia) relacionado aos parâmetros climáticos: Tmax $\left({ }^{\circ} \mathrm{C}\right)$, Tmin $\left({ }^{\circ} \mathrm{C}\right)$, URmax (\%), URmin (\%)

Os animais foram pesados a cada 21 dias conforme procedimento descrito anteriormente. Os resultados das pesagens estão na Tabela 5. Podemos observar que o animal 3 apresentou ligeira redução de peso na segunda pesagem. Este fato ocorreu devido a uma infecção bacteriana causada por agente desconhecido que provocou ligeira depressão de consumo de ração. O animal foi acompanhado por veterinários do Setor de Animais Silvestres da FCAV/UNESP, medicado com antibióticos, recuperando-se após alguns dias e permanecendo no experimento. 
Tabela 5. Resultados das pesagens individuais dos animais

\begin{tabular}{ccccccc}
\hline & \multicolumn{3}{c}{ Pesagens } & \multicolumn{2}{c}{ Pesos $(\mathrm{kg})$} & Peso metabólico \\
\hline Animal & 1 & 2 & 3 & Média & DP & $\left(\mathrm{kg}^{0,75}\right)$ \\
1 & 17,0 & 17,0 & 16,2 & 16,7 & 0,45 & 8,27 \\
2 & 19,6 & 20,0 & 19,6 & 19,7 & 0,20 & 9,36 \\
3 & 17,6 & 15,6 & 18,5 & 17,2 & 1,48 & 8,45 \\
4 & 16,2 & 16,3 & 15,5 & 16,0 & 0,42 & 7,99 \\
5 & 19,5 & 18,3 & 19,2 & 19,0 & 0,65 & 9,09 \\
6 & 18,2 & 18,8 & 19,4 & 18,8 & 0,63 & 9,02 \\
7 & 15,1 & 15,4 & 15,1 & 15,2 & 0,14 & 7,69 \\
8 & 14,8 & 14,5 & 14,4 & 14,6 & 0,22 & 7,45 \\
Média & 17,2 & 17,0 & 17,2 & 17,1 & 0,16 & 8,42 \\
\hline
\end{tabular}

Uma vez determinados o consumo de ração e os pesos dos animais passamos a analisar o consumo de energia propriamente dita para satisfazer as exigências dos animais. Os teores de energia bruta (Mcal) do alimento oferecido e das sobras foram determinados em bomba calorimétrica no Laboratório de Bromatologia da FCAV/UNESP. Para calcular a energia digestível disponível utilizamos o valor de digestibilidade da energia obtido através da metodologia de coleta total de fezes (63\%) obtido por Barbosa (2002a). O valor da energia metabolizável foi estimado, considerando-se o fator de $82 \%$ de eficiência (Van Soest, 1994).

$$
\begin{aligned}
& \operatorname{ED}(\mathrm{kcal} / \mathrm{kg})=\mathrm{EB}(\mathrm{kcal} / \mathrm{kg}) * 0,63 \\
& \operatorname{EM}(\mathrm{kcal} / \mathrm{kg})=\operatorname{ED}(\mathrm{kcal} / \mathrm{kg}) * 0,82
\end{aligned}
$$

Com esta forma de cálculo chegamos ao consumo de energia metabolizável por dia por animal (Tabela 6). O consumo de energia metabolizável por dia por quilo de peso metabólico $\left(\mathrm{kcal} / \mathrm{kg}^{0,75} . \mathrm{d}\right)$ é outra forma de expressar o consumo e nos fornece parâmetro para comparação entre diferentes espécies. 
Tabela 6. Consumo de energia metabolizável por animal

\begin{tabular}{ccccc}
\hline & \multicolumn{2}{c}{ Consumo $($ Mcal $/$ dia $)$} & \multicolumn{2}{l}{ Consumo $\left(\mathrm{Mcal} / \mathrm{kg}^{0,75} \cdot\right.$ dia $)$} \\
\hline Animal & Média & DP & Média & DP \\
1 & 0,827 & 0,152 & 0,100 & 0,018 \\
2 & 1,118 & 0,101 & 0,120 & 0,011 \\
3 & 0,830 & 0,135 & 0,098 & 0,016 \\
4 & 1,002 & 0,093 & 0,125 & 0,012 \\
5 & 0,987 & 0,153 & 0,108 & 0,017 \\
6 & 0,989 & 0,106 & 0,110 & 0,012 \\
7 & 0,916 & 0,143 & 0,119 & 0,019 \\
8 & 0,794 & 0,078 & 0,107 & 0,010 \\
Média & 0,934 & 0,065 & 0,111 & 0,008 \\
\hline
\end{tabular}

Uma vez que os animais não se encontravam em estágio reprodutivo nem em crescimento é considerado que toda energia metabolizável foi utilizada para realização das atividades de manutenção. A média dos 8 animais em todo período experimental foi calculada chegando ao valor da exigência de energia metabolizável para mantença: $111,4 \pm 7,7 \mathrm{kcal} / \mathrm{kg}{ }^{0,75} . \mathrm{d}$.

Este valor determinado através da alimentação controlada por longo período de tempo e manutenção de peso e condição corporal pode ser comparado à metodologia da água duplamente marcada, cujos resultados estão descritos abaixo.

Nas Tabelas 7 e 8 podemos observar os pesos dos animais e das seringas, permitindo a precisa determinação da quantidade de água injetada por animal.

Para a ${ }^{2} \mathrm{H}_{2} \mathrm{O}$ seriam necessários $100,0 \mathrm{mg} / \mathrm{kg}$ de peso vivo e foram injetados em média $111,8 \mathrm{mg} / \mathrm{kg}$. Analogamente foram injetados $163,1 \mathrm{mg} / \mathrm{kg}$ de $\mathrm{H}_{2}{ }^{18} \mathrm{O}$ enquanto o necessário eram 150,0 mg/kg. 
Tabela 7. Peso dos animais, das seringas e quantidade de água marcada $\left({ }^{2} \mathrm{H}_{2} \mathrm{O}\right)$ injetada por animal

\begin{tabular}{|c|c|c|c|c|c|}
\hline \multirow{2}{*}{\multicolumn{2}{|c|}{ Animal }} & & & & \\
\hline & & \multicolumn{2}{|c|}{ Peso da Seringa } & & \\
\hline $\mathrm{n}^{\circ}$. & Peso & Vazia & Cheia & g & $\mathrm{mg} / \mathrm{kg}$ \\
\hline 1 & 17 & 3,09 & 4,97 & 1,88 & 110,6 \\
\hline 2 & 16 & 3,06 & 4,87 & 1,81 & 113,1 \\
\hline 3 & 18 & 3,17 & 5,18 & 2,01 & 111,7 \\
\hline 4 & 15 & 3,09 & 4,71 & 1,62 & 108,0 \\
\hline 5 & 18 & 3,06 & 5,17 & 2,11 & 117,2 \\
\hline 6 & 15 & 3,15 & 4,8 & 1,65 & 110,0 \\
\hline 7 & 16 & 3,05 & 4,85 & 1,8 & 112,5 \\
\hline 8 & 18 & 3,12 & 5,14 & 2,02 & 112,2 \\
\hline 9 & 18 & 3,06 & 5,06 & 2 & 111,1 \\
\hline Média & 16,8 & 3,1 & 5,0 & 1,9 & 111,8 \\
\hline
\end{tabular}

Tabela 8. Peso dos animais, das seringas e quantidade de água marcada $\left(\mathrm{H}_{2}{ }^{18} \mathrm{O}\right)$ injetada por animal

\begin{tabular}{|c|c|c|c|c|c|}
\hline \multicolumn{6}{|c|}{$\mathrm{H}_{2}{ }^{18} \mathrm{O} \quad(150 \mathrm{mg} / \mathrm{kg}$ de peso vivo $)$} \\
\hline \multicolumn{2}{|c|}{ Animal } & \multicolumn{2}{|c|}{ Peso da Seringa } & \multicolumn{2}{|c|}{ Injetado } \\
\hline $\mathrm{n}^{\mathrm{o}}$. & Peso & Vazia & Cheia & $\mathrm{g}$ & $\mathrm{mg} / \mathrm{kg}$ \\
\hline 1 & 17 & 3,13 & 5,83 & 2,7 & 158,8 \\
\hline 2 & 16 & 3,11 & 5,65 & 2,54 & 158,8 \\
\hline 3 & 18 & 3,1 & 5,93 & 2,83 & 157,2 \\
\hline 4 & 15 & 3,1 & 5,53 & 2,43 & 162,0 \\
\hline 5 & 18 & 3,15 & 6,02 & 2,87 & 159,4 \\
\hline 6 & 15 & 3,06 & 5,54 & 2,48 & 165,3 \\
\hline 7 & 16 & 3,09 & 5,76 & 2,67 & 166,9 \\
\hline 8 & 18 & 3,07 & 6,09 & 3,02 & 167,8 \\
\hline 9 & 18 & 3,11 & 6,17 & 3,06 & 170,0 \\
\hline Média & 16,8 & 3,1 & 5,8 & 2,7 & 163,1 \\
\hline
\end{tabular}

As coletas de sangue foram programadas de forma a obter uma curva de desaparecimento dos isótopos bastante clara e precisa, identificando o acentuado aumento na concentração dos isótopos no momento inicial e sua queda gradual com o desaparecimento. Por este motivo foram realizadas mais coletas nos primeiros dias após a aplicação da água duplamente marcada. 
Estabelecer precisamente a curva de desaparecimento dos isótopos para esta espécie contribuirá significativamente para o planejamento de um futuro experimento em vida livre, quando serão realizadas apenas duas coletas devido à dificuldade de recaptura dos animais. A determinação dos melhores pontos para coleta do experimento em vida livre será feita com base do gráfico obtido neste ensaio em cativeiro.

Os resultados das concentrações dos isótopos estáveis, ajustados para a fração da concentração inicial (100\%) estão apresentados nas Tabelas 9 e 10. O animal $\mathrm{n}^{\mathrm{o}} 04$ foi excluído do experimento por ser um ponto "outlier" na determinação do "pool size" e não consta dos cálculos.

Tabela 9. Frações (\%) da concentração inicial do oxigênio $18\left({ }^{18} \mathrm{O}\right)$ em função dos dias do experimento

\begin{tabular}{cccccccccc}
\hline \multicolumn{7}{c}{ Animais } \\
dias & 1 & 2 & 3 & 5 & 6 & 7 & 8 & 9 & média \\
\hline 0 & 100,0 & 100,0 & 100,0 & 100,0 & 100,0 & 100,0 & 100,0 & 100,0 & 100,0 \\
0,17 & 99,2 & 99,7 & 99,3 & 99,2 & 98,9 & 98,9 & 99,6 & 98,5 & 99,2 \\
0,5 & 98,6 & 97,9 & 97,9 & 98,7 & 97,9 & 97,6 & 98,5 & 97,7 & 98,1 \\
1,5 & 95,9 & 95,5 & 95,2 & 96,2 & 95,4 & 94,0 & 95,9 & 95,3 & 95,4 \\
4 & 91,0 & 91,4 & 91,1 & 93,3 & 91,8 & 88,9 & 91,8 & 91,9 & 91,4 \\
7 & 84,2 & 81,7 & 81,5 & & & & & & 82,5 \\
8 & & & & 84,6 & 81,3 & 77,3 & 81,2 & 82,0 & 81,3 \\
9 & 79,3 & 76,8 & 75,3 & 0,0 & 0,0 & 0,0 & 0,0 & 0,0 & 77,1 \\
11 & & & & 77,9 & 73,9 & 69,5 & 72,0 & 74,3 & 73,5 \\
15 & & & & 70,0 & 65,4 & 59,4 & 62,9 & 64,3 & 64,4 \\
16 & 61,2 & 58,4 & 56,2 & & & & & & 58,6 \\
21 & & & & 57,5 & 46,9 & 37,9 & 50,0 & 46,7 & 47,8 \\
30 & & & & 39,8 & 27,4 & 11,2 & 0,0 & 27,0 & 26,3 \\
\hline
\end{tabular}


Tabela 10. Frações da concentração inicial do deutério $\left({ }^{2} \mathrm{H}\right)$ em função dos dias do experimento

\begin{tabular}{cccccccccc}
\hline \multicolumn{7}{c}{ Animais } \\
dias & 1 & 2 & 3 & 5 & 6 & 7 & 8 & 9 & média \\
\hline 0 & 100,0 & 100,0 & 100,0 & 100,0 & 100,0 & 100,0 & 100,0 & 100,0 & 100,0 \\
0,17 & 99,1 & 99,6 & 99,0 & 99,4 & 99,5 & 99,3 & 100,0 & 98,4 & 99,3 \\
0,5 & 98,7 & 97,7 & 97,5 & 98,8 & 98,5 & 98,1 & 98,8 & 97,7 & 98,2 \\
1,5 & 96,1 & 96,0 & 95,3 & 96,7 & 96,4 & 95,5 & 96,6 & 95,3 & 96,0 \\
4 & 91,8 & 92,4 & 91,8 & 94,5 & 93,6 & 90,4 & 93,2 & 92,5 & 92,5 \\
7 & 85,5 & 84,1 & 83,8 & & & & & & 84,5 \\
8 & & & & 87,2 & 84,5 & 80,4 & 84,3 & 84,0 & 84,1 \\
9 & 81,5 & 80,2 & 78,6 & & & & & & 80,1 \\
11 & & & & 81,8 & 78,4 & 73,6 & 77,0 & 77,3 & 77,6 \\
15 & & & & 75,1 & 71,3 & 64,7 & 68,6 & 68,1 & 69,6 \\
16 & 64,2 & 64,6 & 62,2 & & & & & & 63,6 \\
21 & & & & 65,2 & 57,3 & 49,6 & 59,4 & 52,8 & 56,9 \\
30 & & & & 49,8 & 41,6 & 24,5 & 0,0 & 32,9 & 37,2 \\
\hline
\end{tabular}

As curvas de decaimento dos isótopos do oxigênio 18 e deutério para os 8 animais experimentais estão ilustradas na Figura 6.

Tabela 11. Produção de $\mathrm{CO}_{2}$ calculada a partir das constantes de decaimento (kd) e do "Pool size" (N)

\begin{tabular}{ccccccccc}
\hline & 1 & 2 & 3 & 5 & 6 & 7 & 8 & 9 \\
\hline $\mathrm{N}$ & 728,4 & 545,5 & 621,1 & 625,7 & 568,6 & 662,8 & 703,7 & 714,6 \\
$\mathrm{kd} * \mathrm{~N}$ & 76,4 & 62,1 & 76,1 & 52,9 & 55,0 & 79,3 & 69,2 & 77,2 \\
$\mathrm{~N}(\mathrm{ko}-\mathrm{kd}) / 2.08$ & 6,4 & 6,6 & 6,7 & 7,0 & 8,9 & 10,5 & 10,3 & 7,5 \\
$\mathrm{rCO}_{2}(\mathrm{~L})$ & 5,2 & 5,7 & 5,6 & 6,2 & 8,0 & 9,4 & 9,2 & 6,3 \\
\hline
\end{tabular}




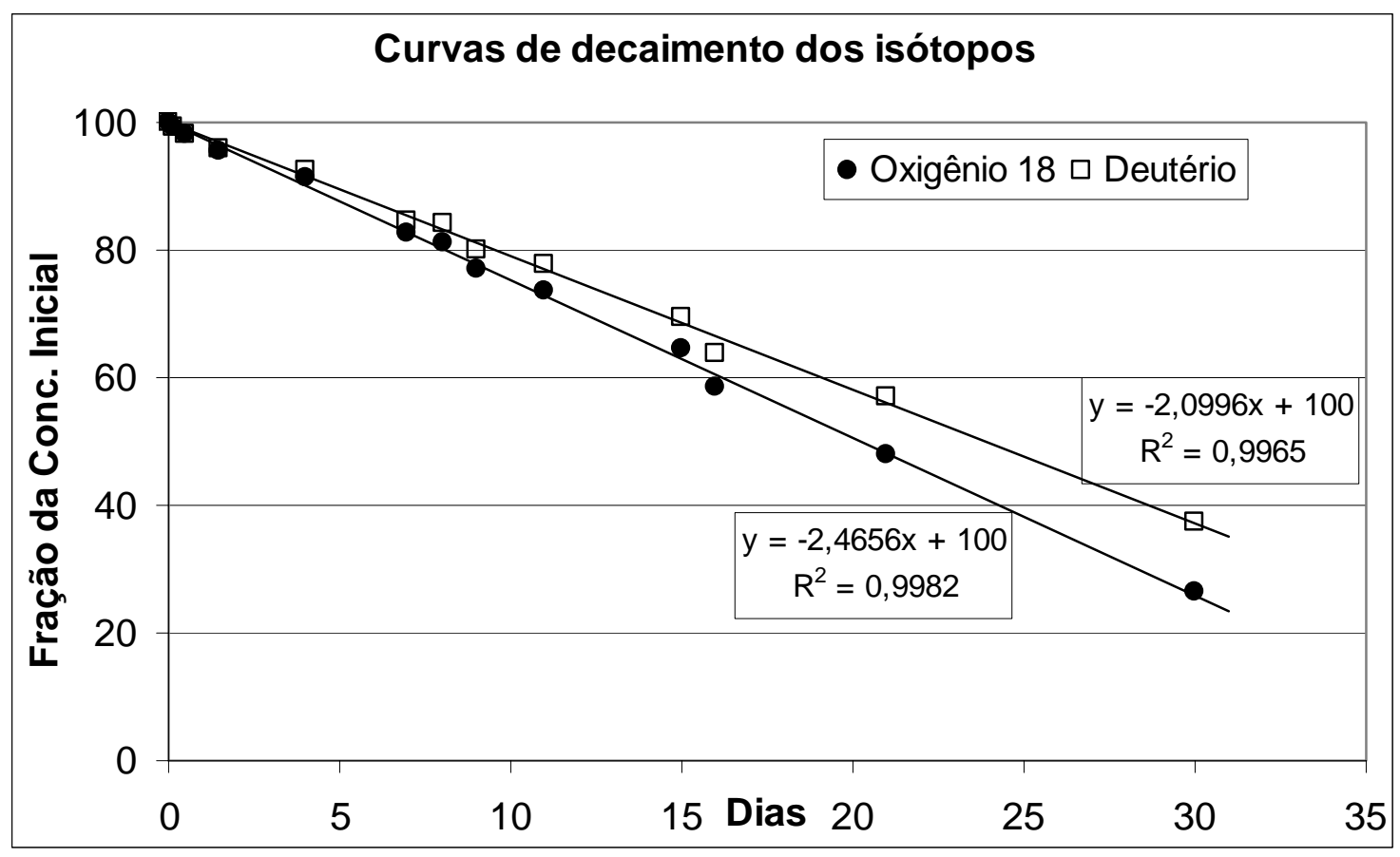

Figura 6 - Curvas de decaimento do ${ }^{18} \mathrm{O}$ e ${ }^{2} \mathrm{H}$ para os 8 animais

A produção de $\mathrm{CO}_{2}$ foi calculada pela diferença entre as taxas fracionais de desaparecimento dos isótopos de oxigênio e hidrogênio e por estimativa do volume total de água corporal do animal (Nagy, 1980). As constantes de decaimento foram obtidas a partir das curvas e o "pool size" foi calculado pelo intercepto destas curvas. Os resultados de produção de $\mathrm{CO}_{2}$ dos 8 animais estão apresentados na Tabela 11.

A determinação da demanda de energia $(\mathrm{kcal} / \mathrm{d})$ foi obtida a partir da equação de Brouwer (1965) considerando que, como os animais estavam sob condição de mantença, a produção de calor por dia equivale à exigência de energia para mantença (Tabela 12). 
Tabela 12. Produção de calor calculada a partir da equação de Brouwer, (1965)

\begin{tabular}{|c|c|c|c|c|c|c|c|c|c|}
\hline \multicolumn{10}{|c|}{ Animais } \\
\hline & 1 & 2 & 3 & 5 & 6 & 7 & 8 & 9 & média \\
\hline \multicolumn{10}{|c|}{ Produção $\mathrm{CO}_{2}$} \\
\hline $\mathrm{rCO}_{2}(\mathrm{~L})$ & 117,2 & 126,7 & 125,7 & 140,0 & 180,0 & 209,8 & 206,5 & 141,9 & 156,0 \\
\hline \multicolumn{10}{|c|}{ Perdas estimadas } \\
\hline $8 \%$ como $\mathrm{CH}_{4}(\mathrm{~L})$ & 9,4 & 10,1 & 10,1 & 11,2 & 14,4 & 16,8 & 16,5 & 11,4 & 12,5 \\
\hline $1 \%$ como $\mathrm{N}_{\text {urina }}(\mathrm{L})$ & 1,2 & 1,3 & 1,3 & 1,4 & 1,8 & 2,1 & 2,1 & 1,4 & 1,6 \\
\hline \multicolumn{10}{|c|}{ Produção de calor } \\
\hline $\mathrm{HP}(\mathrm{kcal} / \mathrm{d})^{*}$ & 700,3 & 757,1 & 751,2 & 836,8 & 1075,9 & 1253,8 & 1234,3 & 848,3 & 932,2 \\
\hline \multicolumn{10}{|c|}{ Gasto energético metabólico } \\
\hline En $\left(\mathrm{kcal} / \mathrm{d} . \mathrm{bw}^{.75}\right)$ & 83,6 & 94,6 & 85,9 & 95,7 & 141,0 & 156,6 & 141,1 & 97,0 & 112,0 \\
\hline
\end{tabular}

A média dos 8 animais em todo período experimental foi calculada chegando ao valor da exigência de energia metabolizável para mantença: 112,0 $\pm 29,2$ $\mathrm{kcal} / \mathrm{kg}^{0,75} \cdot \mathrm{d}$.

Os resultados da demanda de energia metabolizável para mantença, obtido através do método de alimentação controlada por longo período $(111,4 \pm 7,7 \mathrm{kcal} / \mathrm{kg}$ $\left.{ }^{0,75} . \mathrm{d}\right)$ e através do método da água duplamente marcada $\left(112,0 \pm 29,2 \mathrm{kcal} / \mathrm{kg}^{0,75} . \mathrm{d}\right)$ foram semelhantes.

Na Tabela 13 estão listados alguns trabalhos que determinaram as exigências de energia para mantença de outras espécies de ruminantes domésticos e selvagens. Podemos observar que, apesar das espécies citadas serem predominantemente de clima temperado, as exigências de energia são relativamente semelhantes. 
Tabela 13. Exigências de energia para mantença $\left(\mathrm{kcal} / \mathrm{kg}^{.75} . \mathrm{d}\right)$ de outras espécies de ruminantes

\begin{tabular}{ccccc}
\hline Espécie & Nome científico & $\mathrm{Kg}$ & $\begin{array}{c}\mathrm{Kcal} \\
\mathrm{EM} / \mathrm{kg}^{75} . \mathrm{d}\end{array}$ & Referência \\
\hline Fallow deer & Dama dama & 25 & 155,3 & $\mathrm{Ru} \&$ Glatz, 2004 \\
Ovinos & Cervus unicolor & 45 & 113,3 & Semiadi, 1998 \\
Sambar deer & Odocoielus hemionus & 50 & 95 & Parker et al, 1996 \\
Black tailed deer & Odor & 121 & Torien et al, 1999 \\
Black tailed deer & Odocoielus hemionus & 50 & 120 & Parker et al, 1999 \\
Caprinos & & 57 & 101,4 & Torien et al, 1999 \\
White tailed deer & Odocoielus virginianus & 70 & 80,1 & Pekins, 1998 \\
White tailed deer & Odocoielus virginianus & 80 & 94 & DelGiudice, 2000 \\
\hline
\end{tabular}

Nos resultados obtidos neste experimento houve maior diferença entre indivíduos para o método da água duplamente marcada do que entre animais no método da alimentação controlada. Uma justificativa para esta observação pode ser a diferença de comportamento entre os animais. $\mathrm{O}$ animal 04, excluído dos cálculos, consumiu mais água que a média, fato que pode ter causado interferência no "turnover" de água corporal. O animal 07, que apresentou a maior demanda de energia, era o animal mais inquieto e arisco, sempre causando transtornos nos momentos de coleta de sangue.

O experimento com alimentação controlada por longo período estressou menos os animais pois apenas uma vez ao dia a ração e a água eram trocados. Nenhuma intervenção mais intensa, exceto 3 pesagens, foi realizada. No experimento com água duplamente marcada todos os animais eram contidos manualmente pela equipe durante as freqüentes coletas de sangue.

Apesar desta variação entre indivíduos a técnica da água duplamente marcada pode ser utilizada para determinar a demanda de energia de animais em vida livre. Acreditamos inclusive que as diferenças das variações entre animais serão menores pois o ambiente livre condiciona os animais a um estado constante de 
vigília e busca de alimento que equilibra a demanda de energia pelo nível mais alto. As diferenças neste caso sofrerão mais influência de outros fatores como comportamento social, período reprodutivo, época do ano ou disponibilidade de alimento.

\subsection{Conclusões}

A dieta peletizada desenvolvida para o experimento em cativeiro atendeu às exigências nutricionais do veado-catingueiro (Mazama gouazoubira) e pode ser utilizada para manutenção desta espécie em cativeiro.

A exigência de energia para mantença do veado catingueiro em cativeiro foi determinada através do método da água duplamente marcada, obtendo valor médio de $112,0 \pm 29,2 \mathrm{kcal} / \mathrm{kg}^{0,75}$.d. Este valor estimado foi validado através da medição nos mesmos animais pelo método padrão (de equilíbrio de peso). Apesar da variação entre indivíduos a técnica da água duplamente marcada é um método não invasivo com grande potencial para determinar a demanda de energia de animais em vida livre. Com enriquecimento semelhante ao do experimento em cativeiro, 111,8 $\mathrm{mg} / \mathrm{kgPV}$ de ${ }^{2} \mathrm{H}_{2} \mathrm{O}$ e $163,1 \mathrm{mg} / \mathrm{kgPV}$ de $\mathrm{H}_{2}{ }^{18} \mathrm{O}$, a coleta de sangue final poderá ser realizada até 30 dias após a aplicação, permitindo o uso em vida livre. 


\section{ECOLOGIA NUTRICIONAL DO VEADO-CAMPEIRO (OZOTOCEROS BEZOARTICUS) NO PARQUE NACIONAL DAS EMAS, GO}

Resumo

Existem poucas informações sobre exigências de energia de cervídeos brasileiros. O conhecimento das exigências de energia também é importante para determinar os recursos necessários para sua conservação em parques e reservas. $\mathrm{O}$ objetivo deste experimento foi observar o comportamento alimentar do veadocampeiro (Ozotoceros bezoarticus) no Parque Nacional das Emas (PNE), descrevendo qualitativamente e quantitativamente as principais espécies vegetais utilizadas para o aporte de nutrientes. No PNE, veados-campeiro já monitorados com radio colares, permitiram a observação de seu comportamento alimentar. O experimento foi realizado em duas épocas distintas (inverno e verão). As espécies foram analisadas quanto à composição nutricional, para estimar valores energéticos assim como consumo de minerais e proteína. As contribuições das diferentes espécies que compõem a dieta dos cervídeos foram estimadas para duas populações em vida livre, uma com acesso apenas a espécies nativas (área central do parque) e outra com acesso às espécies cultivadas na periferia do PNE. Os sinais isotópicos do carbono 13 e os perfis de n-alcanos foram utilizados para quantificar a contribuição das diferentes espécies ingeridas. Os resultados indicaram que os veados-campeiro utilizam uma ampla gama de partes e espécies vegetais. Sua dieta é composta por aproximadamente 78 ítens, divididos em brotos (38,5\%), folhas (15,4\%), flores $(17,9 \%)$, botões florais $(12,8 \%)$, frutos e sementes $(15,4 \%)$; de 55 diferentes espécies nativas e 7 culturas agrícolas. Há grande diferença no padrão de consumo entre as populações no interior do parque e aquelas que tem possibilidade de selecionar plantas cultivadas pelo 
homem. As espécies agrícolas podem contribuir com até 46,9\% da dieta dos cervídeos da periferia do parque. Este trabalho descreveu as espécies e partes utilizadas como aporte de nutrientes por cervídeos em vida livre.

\section{Summary}

There are limited data on energy requirements of brazilian cervids. Knowing the energy requirements is also important to determine the necessary nutritional resources for their conservation in parks and reserves. The objective of this experiment was to observe the feeding behavior of the pampas-deer (Ozotoceros bezoarticus) in the Emas National Park (ENP), describing qualitatively and quantitatively the main vegetal species used to supply these animals with nutrients. In the national park, pampas-deer already monitored with radio colars, facilitated the observation of their feeding behavior. The experiment was conducted at two distinct seasons (winter and summer). The species were analyzed for the nutritional composition, to estimate energy values as well as mineral and protein consumption. The contributions of the different species to the diet of the cervids were estimated for two free ranging populations of the national park, one with access only to native species (central area of the park) and another with access to the crop species cultivated in the periphery of the park. The isotopic signals of carbon 13 and profiles of n-alkanes were used to quantify the contribution of different species to supply the energy demands. The results indicated that pampas-deer feeds on a broad spectrum parts and vegetal species. Its diet was composed of approximately 78 different parts, divided in sprouts $(38.5 \%)$, leaves $(15.4 \%)$, flowers $(17.9 \%)$, floral buttons $(12.8 \%)$, fruits and seeds (15.4\%); from 55 different native species and 7 agricultural cultures. There is a great difference in the intake selection patterns between populations in the interior of the park and those that have access to cropland and the opportunity to choose feeding on native or cultivated plants. The agricultural species can contribute with up to $46.9 \%$ of deer diet of the park periphery. This work described the species and parts used to supply nutrients to cervids in the wild. 


\subsection{Introdução}

O experimento foi conduzido no Parque Nacional das Emas (PNE), município de Mineiros, sudoeste do Estado de Goiás. Foram realizadas viagens bimestrais para coleta, entre julho de 2002 e julho de 2003.

Alguns estudos foram conduzidos no Parque Nacional das Emas buscando identificar os hábitos alimentares do veado campeiro (Ozotoceros bezoarticus) em vida livre (Frutuoso, 1999; Rodrigues, 1996a, 1996b, 1996c, 2003; Rodrigues e MonteiroFilho, 1996, 1999, 2000). Esses estudos confirmaram que o veado campeiro no PNE apresenta comportamento característico de "browser" segundo a classificação proposta por Bodmer (1989), ingerindo preferencialmente espécies herbáceas, buscando as porções mais nutritivas das plantas.

Os trabalhos anteriores concentraram-se no interior do parque e identificaram apenas as principais partes ingeridas das plantas preferencialmente consumidas. Este estudo teve por objetivos identificar a influência das áreas agrícolas na dieta do veado campeiro e quantificar a participação relativa das principais espécies nativas e cultivadas consumidas.

O parque foi dividido em duas áreas principais: uma marginal (perímetro) onde os animais têm livre acesso a extensas áreas agrícolas contíguas ao parque; e outra mais central (interior), distante pelo menos 5 quilômetros do perímetro do parque, de forma que esses animais dificilmente visitariam as lavouras.

Foram realizadas coletas de fezes e plantas consumidas pelo veado-campeiro em duas áreas distintas do parque: uma no interior e outra na margem do parque, divisa com as áreas agrícolas. Buscou-se identificar a presença de espécies agrícolas cultivadas na margem do parque (soja, milho, algodão, girassol, sorgo e plantas daninhas) nas fezes destes animais. Não era esperado encontrar tais plantas nas fezes dos animais que habitam o interior do parque. Em ambas as áreas os animais ingerem diversas espécies de plantas nativas do cerrado que foram coletadas para identificação taxonômica, caracterização dos teores de proteína, macrominerais e de seu perfil de n-alcanos. 


\subsection{Material e Métodos}

O experimento foi conduzido no Parque Nacional das Emas, Goiás, entre 2002 e 2003. Duas áreas do PNE foram escolhidas para as coletas de fezes e plantas: uma área periférica, às margens do Parque, onde os animais tinham livre acesso a extensas áreas agrícolas contíguas; e outra mais central, distante pelo menos 5 quilômetros do perímetro do parque, de forma que esses animais dificilmente visitariam as lavouras. Para esta estimativa foram considerados os resultados de área de ocupação do veado campeiro no PNE (Rodrigues et al., 2000). A hipótese principal deste estudo era que as dietas dos animais nas duas áreas eram diferentes.

O parque é servido de várias estradas internas e periféricas, paralelas aos aceiros, que delimitam extensas áreas contínuas de vegetação típica de cerrado. A presença de aceiros, constantemente queimados pelos funcionários do Ibama e Brigada de Incêndio, facilitou a coleta pois há uma tendência dos animais se concentrarem onde há brotações mais verdes e plantas mais tenras. Os grupos de animais eram localizados a partir da estrada, forrageando nos aceiros ou campos, acompanhados a pé durante tempo indeterminado, até que fossem coletadas amostras frescas de fezes da maioria dos animais do grupo. Durante o acompanhamento do grupo também eram coletadas amostras das espécies vegetais consumidas no percurso. A proximidade aos animais, cerca de 20 metros em média, permitiu uma identificação precisa das partes consumidas das plantas. Em geral era preciso procurar bastante por exemplares intactos das espécies consumidas para conseguir uma quantidade suficiente de amostra para análise de nalcanos (cerca de $1,00 \mathrm{~kg}$ de amostra verde) e identificação taxonômica. As amostras de plantas foram divididas em 2 grupos: um grupo amplo e completo para identificação taxonômica e caracterização detalhada da dieta e outro menor com as espécies visualmente preferenciais e mais ingeridas para determinação do perfil de n-alcanos e dos teores de macrominerais.

Nem sempre a observação resultou em sucesso e coleta de fezes pois o temperamento de alguns indivíduos e o comportamento arisco, especialmente de fêmeas com filhotes, não permitia aproximação e por vezes todo o grupo fugia em velocidade. Nestes casos o mais prudente foi observar à distância e com o auxílio de binóculo e de 
um distanciômetro ("range finder") identificar os pontos de defecação e buscar a amostra. A amostra de fezes mais distante que foi possível coletar foi localizada a 195 metros. A pelagem branca da região posterior e sub caudal do veado-campeiro contribuiu bastante para a correta determinação do momento da defecação.

As amostras de fezes e de plantas foram armazenadas em sacos plásticos transparentes, identificadas, determinadas e anotadas as coordenadas do ponto de coleta, através de um GPS. Os sacos plásticos deviam ser bem lacrados para evitar o ressecamento das amostras. As amostras foram armazenadas em isopor com gelo dentro do carro até o final do dia, quando ocorria o retorno para o alojamento e as amostras eram finalmente congeladas.

Algumas amostras de plantas eram coletadas com flores e/ou frutos para referência, prensadas imediatamente entre folhas de jornal para posterior identificação taxonômica das espécies ingeridas. A identificação ao nível de espécie foi realizada através de chaves dicotômicas, comparações com o herbário referência do Laboratório de Sistemática Vegetal da ESALQ/USP e consulta a especialistas nas famílias vegetais identificadas.

No laboratório as amostras de fezes e plantas foram secas em estufa a $55^{\circ} \mathrm{C}$, momento em que foram determinados os teores de matéria seca (MS) das amostras. A partir das amostras secas foram realizadas análises de sinais isotópicos do carbono, teores de nitrogênio, macrominerais e o perfil de n-alcanos.

As amostras de plantas e fezes foram analisadas quanto ao sinal isotópico do Carbono, análise que permite a distinção entre plantas de ciclo $\mathrm{C}_{3}$ (predominantemente dicotiledôneas) e $\mathrm{C}_{4}$ (predominantemente gramíneas).

Através da metodologia de n-alcanos buscamos estimar quais foram as espécies mais consumidas nas duas áreas, procurando identificar também a presença de espécies agrícolas nas fezes destes animais, indicativo de que a lavoura contribui para sua dieta. O perfil de n-alcanos foi determinado conforme metodologia descrita por Dillon \& Stakelum (1990) com as modificações propostas por Oliveira (2004).

A área sob cada pico referente a cada n-alcano foi determinada usando um software da ChromQuest em um microcomputador. A identificação de cada n-alcano foi 
feita através da análise de correlação e regressão linear entre o número de carbono da cadeia e o logaritmo dos tempos de retenção (Debbrecht, 1985). As áreas de cada pico foram convertidas às quantidades de cada n-alcano por referência ao padrão interno (ntetratriacontano) segundo McNair \& Bonnelli (1968). Também foram feitas extrações sem a adição do padrão interno nas amostras de plantas, chamadas de "extrações em branco" para verificar se este n-alcano não era um componente natural do perfil de alcanos destas espécies vegetais. Onde ele foi encontrado, sua área foi subtraída daquela detectada usando o padrão. Os cálculos de cada fator de resposta para cada n-alcano foram feitos por referência ao padrão interno usando os procedimentos de Untz (1982).

Com o perfil de n-alcanos das fezes e das plantas, expresso $m g \mathrm{C}_{\mathrm{n}} / \mathrm{kg} \mathrm{MS}$, ajustamos as recuperações fecais dos alcanos $\mathrm{C}_{27}$ a $\mathrm{C}_{33}$, utilizando valores obtidos por Barbosa (2002b). As recuperações fecais dos alcanos de cadeias menores $C_{22}$ a $C_{26}$ foram ajustadas através da regressão com os resultados de Barbosa (2002b). O ajuste com a recuperação fecal foi necessário para podermos utilizar o software "EatWhat" desenvolvido por Dove \& Moore (1996) que estima as quantidades das espécies consumidas através da combinação dos alcanos do "pool" de espécies com o perfil das fezes. Foram selecionadas 30 partes de 18 espécies de plantas preferencialmente consumidas para compor o modelo do "EatWhat".

As 30 partes foram agrupadas em relação aos perfis de n-alcanos utilizando-se o procedimento "cluster" do SAS, considerando como método as distâncias Euclidianas entre grupos. Cada grupo foi definido considerando-se as maiores distâncias entre grupos pois espécies com perfis muito próximos não podem ser diferenciadas pelo modelo "EatWhat" (Dove \& Moore, 1996) e, para uma maior sensibilidade na estimativa da composição botânica da dieta, o conteúdo total de n-alcanos das diferentes espécies vegetais deve ser semelhante mas os perfis devem ser bastante diferentes. Foram definidos 12 grupos de plantas pois esses seriam confrontados com 12 n-alcanos $\left(\mathrm{C}_{22}\right.$ a $\left.\mathrm{C}_{33}\right)$. $\mathrm{O}$ número máximo de espécies que pode ser separado é limitado ao número de n-alcanos usados nas equações de estimativa (Dove \& Moore, 1996). 
Desta forma identificamos a contribuição dos grupos contendo as espécies agrícolas cultivadas e as nativas, estimando a composição botânica da dieta consumida pelos veados-campeiro no Parque Nacional das Emas.

\subsection{Resultados e Discussão}

No período de coletas foram avistados aproximadamente 258 indivíduos dos quais apenas 167 foram coletadas amostras de fezes, indicando uma eficiência de coleta de $65 \%$. Considerando apenas os grupos que permitiram o acompanhamento, cerca de 210 , o aproveitamento na coleta de fezes foi de $80 \%$. Por diversas vezes alguns animais apresentaram-se bastante arredios à presença humana não permitindo aproximação. Por outro lado a maioria dos indivíduos se acostumava à nossa presença permitindo acompanhamento a cerca de 20 metros de distância. A distância média de coleta das fezes, entre o observador e o animal que defecou foi de 53,5 metros, variando entre 195 e 14 metros.

Foi estipulado um número mínimo de 10 amostras de fezes por área escolhida (interior e perímetro) a cada viagem. Para atingir esta meta, em algumas viagens, foi necessário andar até $450 \mathrm{~km}$ dentro do parque em busca dos animais. Em janeiro e março de 2003, especificamente, foi bastante difícil encontrar os animais pois esses estavam em fase de acasalamento e bastante ariscos. Nos meses de seca (julho e setembro) os animais encontravam-se em grande grupos (6 a 10 animais) e em geral se alimentando nos aceiros, facilitando significativamente sua localização e acompanhamento.

Das amostras de fezes coletadas entre julho de 2002 e julho de 2003 os animais foram avistados em grupos de 3,21 ( \pm 2,31) indivíduos, variando entre 10 e 1 indivíduo(s) por grupo, média maior do que a observada por Rodrigues (1996b) de 1,97 $( \pm 1,38)$. O objetivo de coletar as fezes de todos ou da maioria dos animais do grupo obrigava o acompanhamento do mesmo por mais tempo, contribuindo para o maior índice de tamanho de grupo.

Durante o acompanhamento dos grupos de veados-campeiro pudemos observar apenas em 2 momentos a relação com grupos de emas (Rhea americana) descrita por 
Rodrigues \& Monteiro-Filho (1996). Em ambos momentos os grupos de emas se mostraram mais ariscos e fugiram, provocando a fuga conjunta do grupo de veadoscampeiro.

Foram identificadas, através de observações visuais, 55 espécies vegetais nativas e 7 espécies cultivadas e plantas daninhas associadas consumidas pelos veadoscampeiro. Das 55 espécies nativas identificadas, 14 foram consumidas de forma preferencial, correspondendo a aproximadamente $25,5 \%$ do total de plantas. Jackson \& Giulietti (1988) estudando uma população de veados-campeiro em campos nativos da Argentina identificaram 24 espécies consumidas, sendo 13 preferenciais (54\%). Nesse estudo a população de veados-campeiro dividia o campo com herbívoros domésticos como cavalos e bovinos, o que contribuía para a redução da diversidade e disponibilidade de forragem, fato que não ocorre no Parque Nacional das Emas.

A relação das espécies nativas consumidas e as respectivas partes ingeridas pelos veados-campeiro no Parque Nacional das Emas está no Quadro 1.

\begin{tabular}{|lll|}
\hline Família & Espécie & Parte ingerida \\
\hline ANACARDIACEAE & Anacardium humile A. St.-Hil. & Broto \\
ANNONACEAE & Annona tomentosa R.E. Fr. & Fruto \\
& Annona warmingiana Mello-Silva \& Pirani & Fruto \\
& Duguetia furfuracea (A. St.-Hil.) Saff. & Fruto \\
APOCYNACEAE & Himatanthus obovatus (Müll. Arg.) Woodson & Broto \\
ARECACEAE & Allagoptera sp. & Flor / Fruto \\
& Bactris penicillata Barb. Rodr. & Folha \\
& Syagrus petraea (Mart.) Becc. & Flor / Fruto \\
& Riencourtia sp. & Flor \\
& Eupatorium squalidum DC. & Broto \\
& Calea sp. & Flor \\
& Calea cuneifolia DC. & Flor \\
& Vernonia coriacea Less & Broto \\
& Vernonia grandiflora Less & Botão floral \\
& Vernonia sp. & Botão floral \\
Quadro 1 - Relação das espécies e respectivas partes consumidas pelos veados-campeiro no PNE
\end{tabular}

Quadro 1 - Relação das espécies e respectivas partes consumidas pelos veados-campeiro no PNE 


\begin{tabular}{|c|c|c|}
\hline Família & Espécie & Parte ingerida \\
\hline \multirow[t]{4}{*}{ BIGNONIACEAE } & Jacaranda rufa Silva Manso & Broto \\
\hline & Anemopaegma arvense (Vell.) Stellfeld ex de & Broto/Flor \\
\hline & Souza & \\
\hline & Jacaranda decurrens Cham. & Broto/Flor \\
\hline BOMBACACEAE & Pseudobombax sp. & Broto/ Folha \\
\hline BURSERACEAE & Protium ovatum Engl. & Botão floral \\
\hline CLUSIACEAE & Kielmeyera variabilis Mart. & Broto/Botão floral \\
\hline CONNARACEAE & Rourea induta Planch. & Broto \\
\hline CONVOLVULACEAE & Merremia digitata (Spreng.) Hallier f. & Broto/Folha \\
\hline CYPERACEAE & Rhynchospora sp. & Folha, flor \\
\hline DILLENIACEAE & Davilla elliptica A. St.-Hil. & Fruto \\
\hline EBENACEAE & Diospyros hispida A. DC. & Flor \\
\hline EUPHORBIACEAE & Manihot gracilis Pohl & Broto, folha, fruto \\
\hline LAMIACEAE & Hyptis villosa Pohl ex Benth. & Broto \\
\hline \multirow{3}{*}{$\begin{array}{l}\text { LEGUMINOSAE- } \\
\text { Caesalpinioideae }\end{array}$} & Senna rugosa (G. Don) H.S. Irwin \& Barneby & Broto \\
\hline & Senna silvestris (Vell.) H.S. Irwin \& Barneby & Broto, Botão floral \\
\hline & Bauhinia holophylla (Bong.) Steud. & Botão floral, Flor \\
\hline \multirow{4}{*}{$\begin{array}{l}\text { LEGUMINOSAE- } \\
\text { Faboideae }\end{array}$} & Clitoria sp. & Broto \\
\hline & Galactia cf. Martii DC. & Folha \\
\hline & Acosmium dasycarpum (Vogel) Yakovlev & Folha \\
\hline & Acosmium subelegans (Mohlenbr.) Yakovlev & Broto \\
\hline \multirow{7}{*}{$\begin{array}{l}\text { LEGUMINOSAE- } \\
\text { Mimosoideae }\end{array}$} & Mimosa dumetorum A. St.-Hil. & Broto \\
\hline & Mimosa dumetorum A. St.-Hil. & Broto \\
\hline & Mimosa cf. xanthocentra Mart. & $\begin{array}{l}\text { Broto, botão, flor, } \\
\text { fruto }\end{array}$ \\
\hline & Stryphnodendron adstringens (Mart.) Coville & Broto/Folha/Fruto \\
\hline & Anadenanthera sp. & Broto/Folha \\
\hline & Mimosa sp. & Flor \\
\hline & Calliandra dysantha Benth. & Flor \\
\hline \multirow[t]{2}{*}{ MALPIGHIACEAE } & Camarea sp. & Botão floral \\
\hline & Byrsonima basiloba A. Juss. & Flor \\
\hline \multirow[t]{2}{*}{ MYRTACEAE } & Eugenia sp. & Broto \\
\hline & Myrciaria sp. & Broto \\
\hline ONAGRACEAE & Ludwigia cf. elegans (Cambess.) H. Hara & Botão floral \\
\hline
\end{tabular}




\begin{tabular}{|c|c|c|}
\hline Família & Espécie & Parte ingerida \\
\hline POACEAE & Indet. 1 & Folha \\
\hline RUBIACEAE & $\begin{array}{l}\text { Diodia cf. radula (Willd. \& Hoffmanns. Ex Roem. } \\
\text { \& Schult.) Cham. \& Schltdl. } \\
\text { Palicourea rigida Kunth }\end{array}$ & $\begin{array}{l}\text { Broto } \\
\text { Broto }\end{array}$ \\
\hline RUTACEAE & Spiranthera odoratissima A. St.-Hil. & Botão floral \\
\hline \multirow[t]{2}{*}{ SAPINDACEAE } & Talisia angustifolia Radlk. & Broto \\
\hline & Serjania lethalis A. St.-Hil. & Folha \\
\hline SMILACACEAE & Smilax sp. & Folha \\
\hline SOLANACEAE & Solanum lycocarpum & Fruto \\
\hline
\end{tabular}

Quadro 1 - Relação das espécies e respectivas partes consumidas pelos veados-campeiro no PNE

A dieta do veado-campeiro no PNE é composta por aproximadamente 78 ítens, representados por 55 espécies nativas, 7 culturas agrícolas e plantas daninhas associadas. Os 78 ítens podem ser divididos em brotos $(38,5 \%)$, folhas $(15,4 \%)$, flores $(17,9 \%)$, botões florais $(12,8 \%)$, frutos e sementes $(15,4 \%)$.

Rodrigues (1999) identificou que os veados-campeiro do PNE alimentavam-se principalmente de herbáceas e flores, seguidos por arbustos e gramíneas. Apesar da diversidade de ítens disponíveis os animais ingeriram preferencialmente as partes mais tenras e suculentas, aparentemente mais digestíveis como folhas, brotos e flores, fato que também foi claramente observado neste trabalho.

As principais frações ingeridas das plantas, identificadas neste estudo, foram folhas novas, brotos e flores de dicotiledôneas, semelhantes aos resultados de Rodrigues \& Monteiro-Filho (2000). Embora as populações de veado campeiro da Argentina se alimentem preferencialmente de gramíneas (Jackson \& Giulietti, 1988; Merino, 1998) no Parque Nacional da Emas estas são raramente ingeridas, apesar de sua grande abundância (Rodrigues, 1999). O veado campeiro no PNE apresenta comportamento característico de browser segundo a classificação proposta por Bodmer (1990), ingerindo preferencialmente espécies herbáceas, buscando as porções mais nutritivas das plantas.

A disponibilidade destas partes das plantas é maior na época chuvosa mas a biomassa vegetal total não varia significativamente ao longo do ano (Rodrigues, 1996c). No Parque Nacional das Emas há particularmente uma grande disponibilidade de brotos 
na época da seca (junho e julho) devido às queimadas de aceiros ao longo das estradas que cortam e circundam todo o Parque. A área queimada intencionalmente nestes meses atinge cerca de $5 \%$ da área do Parque (6.500ha). O fogo influencia o deslocamento de veados-campeiro, primeiramente causando fuga e posteriormente os atraindo devido à intensa rebrota que ocorre após a queimada (Frutuoso, 1999).

Em diversos momentos durante o período de coleta foi observada a ingestão de cinzas, cascas queimadas e de terra, principalmente da base de cupinzeiros, pelos veados-campeiros, em busca de suplementação mineral, fato também observado por Rodrigues (1996a). O período de seca e de queimada dos aceiros, de maio a agosto, coincide com o crescimento de chifres dos machos de veado campeiro (Rodrigues, 1996a).

Os resultados da análise química de cinzas, proteína e macrominerais das partes ingeridas das principais espécies estão relacionados na Tabela 13.

Tabela 13. Teores de cinzas, proteína e macrominerais das espécies e respectivas partes consumidas pelos veados- campeiro no PNE

\begin{tabular}{|c|c|c|c|c|c|c|c|c|}
\hline Planta / Espécie & Parte Ingerida & $\%$ Cinzas & \% Proteína & $\begin{array}{l}\% \\
\mathrm{P}\end{array}$ & $\% \mathrm{~K}$ & $\% \mathrm{Ca}$ & $\% \mathrm{Mg}$ & $\% \mathrm{~S}$ \\
\hline $\begin{array}{l}\text { Euphorbia } \\
\text { heterophylla }\end{array}$ & broto 1 & 11,1 & 19,6 & 4,1 & 21,4 & 10,1 & 5,8 & 1,9 \\
\hline $\begin{array}{l}\text { Euphorbia } \\
\text { heterophylla }\end{array}$ & broto 2 & 11,7 & 6,8 & 2,1 & 15,0 & 9,7 & 4,5 & 1,3 \\
\hline $\begin{array}{l}\text { Annona tomentosa } \\
\text { R.E. Fr. }\end{array}$ & fruto & 13,2 & 9,3 & 1,2 & 11,2 & 1,5 & 0,6 & 0,5 \\
\hline Riencourtia sp. & botão floral & 7,0 & 7,4 & 1,4 & 13,5 & 3,8 & 2,3 & 0,6 \\
\hline $\begin{array}{l}\text { Stryphnodendron } \\
\text { adstringens (Mart.) } \\
\text { Coville }\end{array}$ & broto & 3,6 & 22,1 & 2,7 & 11,7 & 0,6 & 1,1 & 0,9 \\
\hline $\begin{array}{l}\text { Stryphnodendron } \\
\text { adstringens (Mart.) } \\
\text { Coville }\end{array}$ & folha & 7,7 & 20,9 & 0,8 & 3,6 & 0,5 & 0,5 & 0,8 \\
\hline $\begin{array}{l}\text { Stryphnodendron } \\
\text { adstringens (Mart.) } \\
\text { Coville }\end{array}$ & fruto & 3,3 & 11,3 & 0,9 & 7,4 & 0,8 & 0,9 & 1,0 \\
\hline $\begin{array}{l}\text { Bauhinia } \\
\text { holophylla (Bong.) } \\
\text { Steud. }\end{array}$ & botão floral 1 & 3,9 & 17,5 & 2,1 & 13,8 & 3,0 & 2,5 & 1,0 \\
\hline $\begin{array}{l}\text { Bauhinia } \\
\text { holophylla (Bong.) } \\
\text { Steud. }\end{array}$ & botão floral 2 & 5,5 & 15,3 & 2,0 & 15,6 & 2,0 & 2,2 & 0,8 \\
\hline
\end{tabular}


Tabela 13. Teores de cinzas, proteína e macrominerais das espécies e respectivas partes consumidas pelos veados- campeiro no PNE

\begin{tabular}{|c|c|c|c|c|c|c|c|c|}
\hline Planta / Espécie & Parte Ingerida & $\%$ Cinzas & $\%$ Proteína & $\% \mathrm{P}$ & $\% \mathrm{~K}$ & $\% \mathrm{Ca}$ & $\% \mathrm{Mg}$ & $\% \mathrm{~S}$ \\
\hline $\begin{array}{l}\text { Bauhinia } \\
\text { holophylla (Bong.) } \\
\text { Steud. }\end{array}$ & flor & 8,1 & 12,4 & 2,1 & 13,0 & 3,4 & 2,6 & 0,8 \\
\hline Portulaca oleracea & broto & 2,3 & 13,6 & 2,0 & 13,8 & 11,4 & 2,1 & 3,1 \\
\hline $\begin{array}{l}\text { Braquiaria } \\
\text { decumbens }\end{array}$ & sementes & 8,1 & 6,8 & 1,3 & 9,2 & 0,7 & 1,2 & 0,9 \\
\hline $\begin{array}{l}\text { Calliandra } \\
\text { dysantha Benth. }\end{array}$ & flor & 3,1 & 11,4 & 1,4 & 9,9 & 0,8 & 1,0 & 0,7 \\
\hline Mimosa sp. & folha & 3,3 & 18,4 & 0,9 & 4,1 & 1,9 & 1,6 & 0,6 \\
\hline Mimosa sp. & broto & 5,5 & 19,2 & 2,4 & 11,5 & 1,2 & 1,3 & 0,9 \\
\hline Smilax sp. & broto & 3,5 & 12,6 & 1,1 & 8,7 & 2,7 & 1,9 & 0,7 \\
\hline $\begin{array}{l}\text { Serjania lethalis A. } \\
\text { St.-Hil. }\end{array}$ & broto & 2,6 & 11,8 & 1,9 & 15,6 & 2,3 & 2,0 & 0,7 \\
\hline $\begin{array}{l}\text { Solanum } \\
\text { lycocarpum }\end{array}$ & casca & 3,2 & 8,7 & 0,6 & 23,5 & 0,3 & 0,2 & 0,5 \\
\hline $\begin{array}{l}\text { Solanum } \\
\text { lycocarpum }\end{array}$ & polpa & 3,2 & 7,5 & 3,2 & 21,9 & 0,6 & 1,3 & 1,4 \\
\hline Calea sp. & Flor 1 & 10,0 & 13,4 & 2,2 & 23,0 & 3,4 & 2,4 & 0,9 \\
\hline Calea sp. & Flor 2 & 11,1 & 12,1 & 2,1 & 23,0 & 3,0 & 2,4 & 0,9 \\
\hline Zea mays & cartucho & 5,7 & 19,4 & 4,5 & 48,2 & 0,6 & 1,4 & 1,3 \\
\hline Zea mays & folha & 2,5 & 20,9 & 3,1 & 36,0 & 1,2 & 1,3 & 1,2 \\
\hline $\begin{array}{l}\text { Syagrus petraea } \\
\text { (Mart.) Becc. }\end{array}$ & fruto & 4,1 & 11,6 & 2,5 & 14,3 & 3,0 & 2,9 & 1,4 \\
\hline $\begin{array}{l}\text { Mimosa cf. } \\
\text { xanthocentra Mart. }\end{array}$ & broto & 2,6 & 18,4 & 1,9 & 10,5 & 1,9 & 1,5 & 0,7 \\
\hline $\begin{array}{l}\text { Mimosa cf. } \\
\text { xanthocentra Mart. }\end{array}$ & flor & 3,3 & 12,8 & 1,0 & 7,1 & 1,7 & 1,5 & 0,6 \\
\hline $\begin{array}{l}\text { Mimosa cf. } \\
\text { xanthocentra Mart. }\end{array}$ & folha & 4,6 & 19,5 & 1,8 & 8,4 & 1,6 & 1,7 & 0,7 \\
\hline $\begin{array}{l}\text { Mimosa cf. } \\
\text { xanthocentra Mart. }\end{array}$ & $\begin{array}{l}\text { fruto e } \\
\text { semente }\end{array}$ & 4,7 & 9,6 & 1,2 & 7,7 & 2,6 & 1,7 & 0,6 \\
\hline Glycine hispida & folha & 1,9 & 27,9 & 2,6 & 11,7 & 12,5 & 4,2 & 1,6 \\
\hline Glycine hispida & fruto & 7,7 & 29,2 & 3,2 & 21,4 & 4,5 & 3,9 & 1,5 \\
\hline Glycine hispida & broto 1 & 3,0 & 34,3 & 4,5 & 32,4 & 6,2 & 3,5 & 1,9 \\
\hline Glycine hispida & broto 2 & 3,2 & 32,8 & 4,9 & 32,1 & 4,9 & 3,5 & 2,3 \\
\hline Sorghum bicolor & folha & 3,0 & 22,7 & 3,3 & 35,7 & 2,0 & 2,6 & 1,3 \\
\hline Sorghum bicolor & grão & 2,4 & 13,1 & 2,0 & 3,8 & 0,4 & 1,0 & 0,7 \\
\hline $\begin{array}{l}\text { Manihot gracilis } \\
\text { Pohl }\end{array}$ & folha & 3,6 & 16,9 & 2,3 & 13,0 & 1,7 & 2,3 & 0,9 \\
\hline $\begin{array}{l}\text { Manihot gracilis } \\
\text { Pohl }\end{array}$ & broto & 3,3 & 17,1 & 2,4 & 13,8 & 1,6 & 1,3 & 1,5 \\
\hline
\end{tabular}


A análise dos diferentes sinais isotópicos do carbono 13 foi utilizada para determinar as concentrações de plantas $C_{3}$ e $C_{4}$ ingeridas pois em geral as plantas $C_{3}$ possuem sinal isotópico médio de -28 e as plantas $C_{4}$ de -11 (Jones et al., 1979). Nesse trabalho as espécies $\mathrm{C}_{3}$ coletadas no PNE apresentaram sinal de $-28,4$ e as espécies agrícolas $\mathrm{C}_{4}$ apresentaram sinal médio de $-12,1$.

Os sinais isotópicos do carbono 13 das amostras de plantas e fezes estão na Figura 7. Neste mesmo gráfico estão identificadas as médias dos sinais das espécies $\mathrm{C}_{3} \mathrm{e}$ $\mathrm{C}_{4}$ ingeridas pelos animais no PNE.

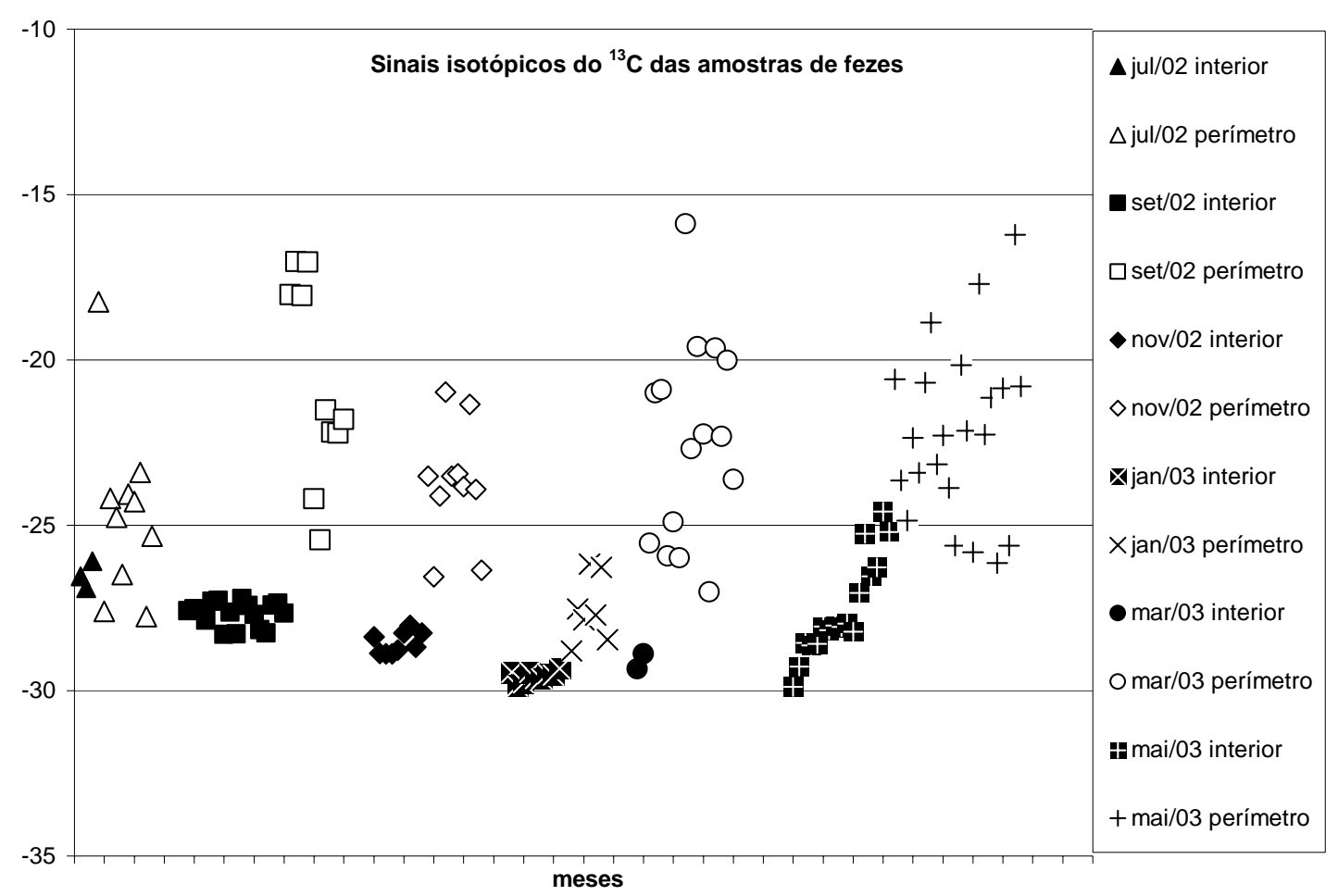

Figura 7 - Sinais isotópicos do ${ }^{13} \mathrm{C}$ das amostras de fezes

Considerando que os sinais isotópicos do ${ }^{13} \mathrm{C}$ das plantas $\mathrm{C}_{3}$ e $\mathrm{C}_{4}$ da dieta são conhecidos podemos assumir que o sinal isotópico das fezes será diretamente proporcional às quantidades de plantas $C_{3}$ e $C_{4}$ ingeridas (Jones et al., 1979). 
A maior restrição a esta correlação linear é a diferença na digestibilidade das diferentes plantas. O veado-campeiro é uma espécie "browser" e seleciona bastante as partes das plantas a serem ingeridas. Esta característica, adicionada às observações visuais in loco do que realmente foi ingerido pelos animais nos dá indícios de que a diferença na digestibilidade dos diferentes elementos da dieta não interferiu significativamente na correlação do sinal isotópico da mistura de plantas nas fezes.

Nas Figuras 8 e 9 estão as proporções calculadas de plantas $\mathrm{C}_{3} \mathrm{eC}_{4}$ ingeridas nas duas áreas distintas do parque: interior e perímetro.

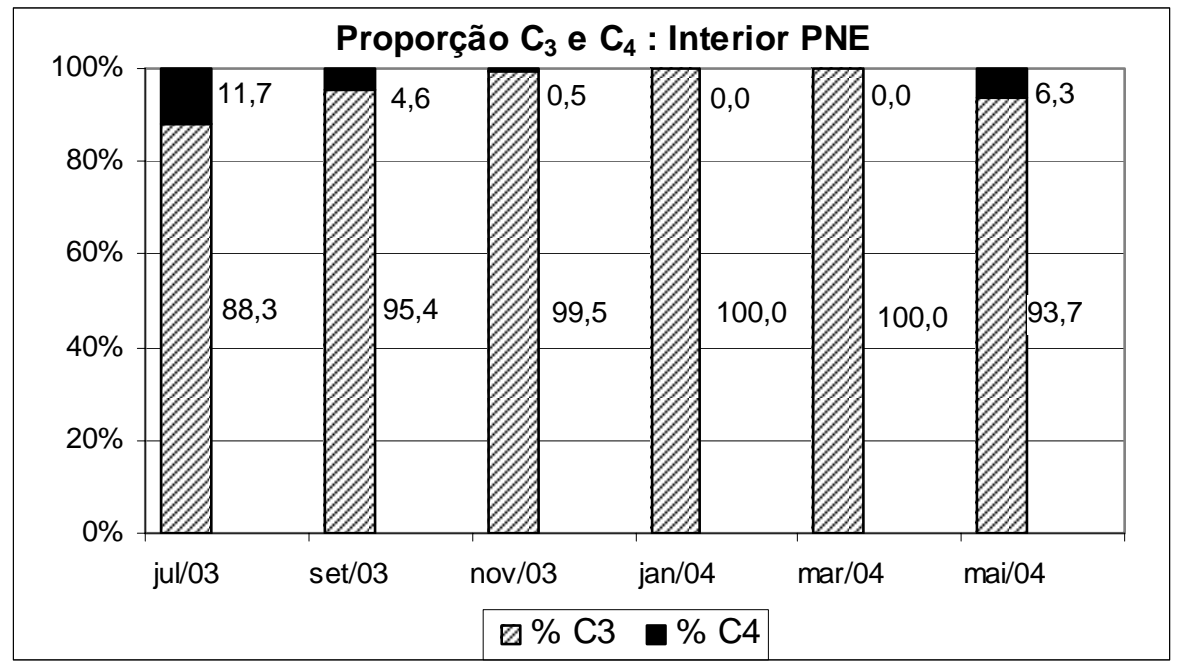

Figura 8 - Proporção de $\mathrm{C}_{3}$ e $\mathrm{C}_{4}$ nas fezes coletadas no interior do Parque

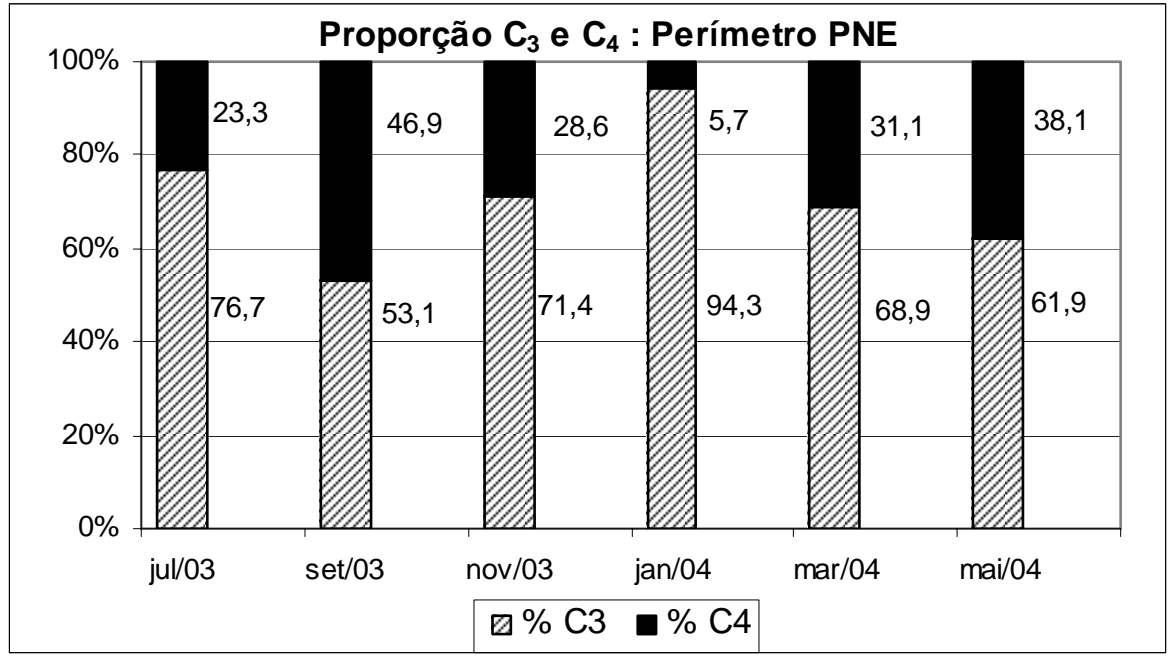

Figura 9 - Proporção de $\mathrm{C}_{3}$ e $\mathrm{C}_{4}$ nas fezes coletadas no perímetro do Parque 
Podemos observar na Tabela 14 que os animais do interior do parque se alimentam principalmente de espécies $\mathrm{C}_{3}$, utilizando muito pouco as gramíneas $\mathrm{C}_{4}$. $\mathrm{O}$ grupo que habita o perímetro do Parque e ocupa as lavouras, por outro lado, chega a consumir $47 \%$ de gramíneas quando a cultura está em fase juvenil (seedling até 4-5 folhas).

Tabela 14. \% de ingestão de gramíneas $\mathrm{C}_{4}$ nas duas áreas do PNE

\begin{tabular}{lcc}
\hline & Interior & Perímetro \\
\hline Julho 2003 & 11,7 & 23,3 \\
Setembro 2003 & 4,6 & 46,9 \\
Novembro 2003 & 0,5 & 28,6 \\
Janeiro 2004 & 0,0 & 5,7 \\
Março 2004 & 0,0 & 31,1 \\
Maio 2004 & 6,3 & 38,1 \\
Seca (mai, jul, set) & 7,5 & 36,1 \\
Chuva (nov, jan, mar) & 0,2 & 21,7
\end{tabular}

$\mathrm{O}$ fato de os animais habitantes do perímetro ingerirem significativamente mais gramíneas que os do interior comprova que o veado campeiro se alimenta de espécies agrícolas cultivadas no entorno, especialmente de brotos de milho e sorgo.

Assim como o veado-de-cauda-branca (Odocoileus virginianus), o veado campeiro também se adapta às transformações do ambiente causadas pelo homem, usando as áreas agrícolas como fonte complementar de alimento.

As análises de n-alcanos das principais plantas ingeridas pelos animais estão nas Tabelas 15 e 16. 
Tabela 15. Perfil de n-alcanos $\left(\mathrm{C}_{22}\right.$ a $\left.\mathrm{C}_{27}\right)$ das partes e plantas mais ingeridas

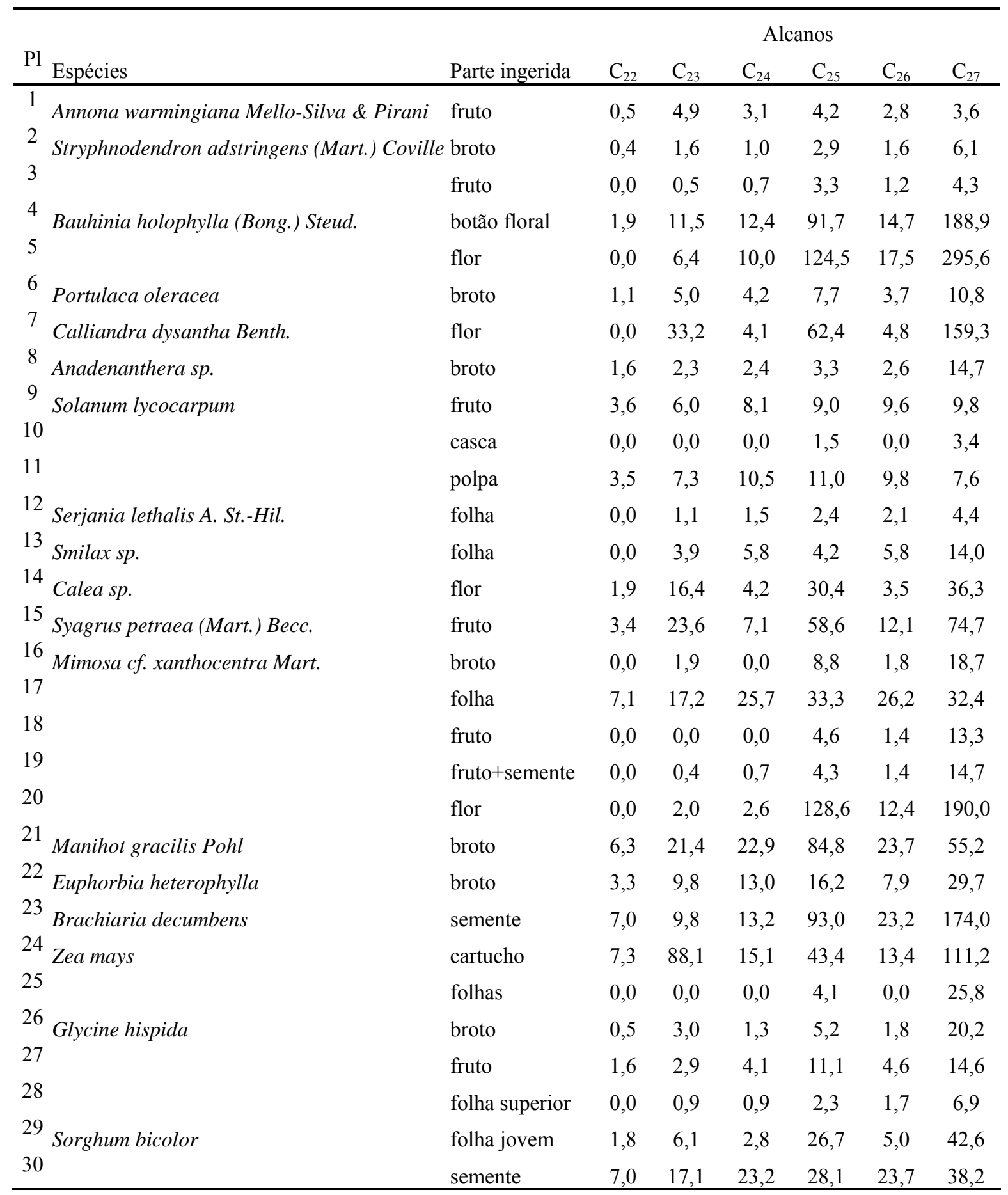


Tabela 16. Perfil de n-alcanos $\left(\mathrm{C}_{28}\right.$ a $\left.\mathrm{C}_{33}\right)$ das partes e plantas mais ingeridas

\begin{tabular}{|c|c|c|c|c|c|c|c|c|}
\hline \multirow[b]{2}{*}{$\mathrm{Pl}$} & \multirow[b]{2}{*}{ Espécies } & \multirow[b]{2}{*}{ Parte ingerida } & \multicolumn{6}{|c|}{ Alcanos } \\
\hline & & & $\mathrm{C}_{28}$ & $\mathrm{C}_{29}$ & $\mathrm{C}_{30}$ & $\mathrm{C}_{31}$ & $\mathrm{C}_{32}$ & $\mathrm{C}_{33}$ \\
\hline \multirow{2}{*}{$\begin{array}{l}1 \\
2\end{array}$} & Annona warmingiana Mello-Silva \& Pirani & fruto & 1,7 & 3,8 & 0,7 & 1,8 & 0,4 & 0,6 \\
\hline & Stryphnodendron adstringens (Mart.) Coville & broto & 2,0 & 9,0 & 1,0 & 1,3 & 0,5 & 0,7 \\
\hline 3 & & fruto & 1,2 & 3,9 & 0,7 & 1,0 & 0,2 & 0,6 \\
\hline \multirow{2}{*}{$\begin{array}{l}4 \\
5\end{array}$} & Bauhinia holophylla (Bong.) Steud. & botão floral & 6,6 & 38,3 & 2,0 & 7,4 & 1,0 & 2,4 \\
\hline & & flor & 7,4 & 32,5 & 0,0 & 7,8 & 0,0 & 3,0 \\
\hline \multirow{2}{*}{$\begin{array}{l}6 \\
7\end{array}$} & Portulaca oleracea & broto & 5,3 & 25,6 & 7,0 & 31,4 & 6,2 & 10,3 \\
\hline & Calliandra dysantha Benth. & flor & 24,9 & 402,3 & 8,2 & 77,4 & 2,0 & 6,5 \\
\hline 8 & Anadenanthera sp. & broto & 4,2 & 25,8 & 1,4 & 2,1 & 0,5 & 1,1 \\
\hline \multirow{2}{*}{$\begin{array}{c}9 \\
10\end{array}$} & Solanum lycocarpum & fruto & 9,3 & 8,4 & 6,6 & 5,3 & 3,7 & 2,2 \\
\hline & & casca & 0,0 & 6,5 & 1,8 & 17,0 & 1,5 & 4,1 \\
\hline 11 & & polpa & 4,2 & 3,0 & 1,2 & 1,6 & 0,6 & 0,6 \\
\hline \multirow{3}{*}{$\begin{array}{l}12 \\
13 \\
14\end{array}$} & Serjania lethalis A. St.-Hil. & folha & 2,7 & 15,4 & 7,6 & 38,6 & 3,3 & 11,3 \\
\hline & Smilax sp. & folha & 5,2 & 52,1 & 6,2 & 81,6 & 5,3 & 14,5 \\
\hline & Calea sp. & flor & 6,7 & 98,6 & 8,6 & 77,0 & 3,4 & 9,5 \\
\hline 15 & Syagrus petraea (Mart.) Becc. & fruto & 9,1 & 28,7 & 3,3 & 9,1 & 1,1 & 1,2 \\
\hline \multirow{2}{*}{$\begin{array}{l}16 \\
17\end{array}$} & Mimosa cf. xanthocentra Mart. & broto & 3,0 & 18,2 & 0,0 & 3,0 & 0,0 & 0,0 \\
\hline & & folha & 14,4 & 25,1 & 3,4 & 4,4 & 1,2 & 1,3 \\
\hline \multirow[t]{2}{*}{18} & & fruto & 2,1 & 13,4 & 0,7 & 6,6 & 0,0 & 0,7 \\
\hline & & fruto + semente & 2,7 & 15,1 & 1,4 & 6,2 & 0,7 & 1,5 \\
\hline 20 & & flor & 15,2 & 123,8 & 6,8 & 57,6 & 3,2 & 9,7 \\
\hline \multirow{2}{*}{$\begin{array}{l}21 \\
22\end{array}$} & Manihot gracilis Pohl & broto & 15,3 & 104,2 & 9,4 & 68,8 & 4,3 & 9,7 \\
\hline & Euphorbia heterophylla & broto & 4,9 & 48,3 & 4,1 & 98,0 & 4,0 & 26,6 \\
\hline 23 & Brachiaria decumbens & semente & 29,4 & 243,8 & 28,3 & 233,5 & 17,6 & 123,8 \\
\hline \multirow{2}{*}{$\begin{array}{l}24 \\
25\end{array}$} & Zea mays & cartucho & 9,1 & 169,6 & 5,9 & 133,6 & 4,7 & 103,7 \\
\hline & & folhas & 2,3 & 80,9 & 6,2 & 154,0 & 6,3 & 115,5 \\
\hline \multirow{3}{*}{$\begin{array}{l}26 \\
27\end{array}$} & Glycine hispida & broto & 2,2 & 21,3 & 1,3 & 17,6 & 0,8 & 1,3 \\
\hline & & fruto & 3,1 & 17,2 & 81,6 & 89,6 & 6,6 & 15,6 \\
\hline & & folha superior & 3,4 & 17,8 & 6,8 & 82,6 & 9,4 & 8,0 \\
\hline \multirow{2}{*}{$\begin{array}{l}29 \\
30\end{array}$} & Sorghum bicolor & folha jovem & 4,6 & 129,7 & 3,7 & 68,4 & 1,7 & 30,8 \\
\hline & & semente & 12,4 & 34,6 & 20,1 & 6,1 & 1,2 & 1,9 \\
\hline
\end{tabular}


As plantas foram agrupadas em relação aos perfis de n-alcanos utilizando-se o procedimento "cluster" do SAS, considerando como método as distâncias Euclidianas entre grupos. Neste cálculo foram utilizadas as 30 partes vegetais mais ingeridas representando as 18 principais espécies vegetais selecionadas pelos animais. $\mathrm{O}$ resultado dos agrupamentos está na Figura 10.

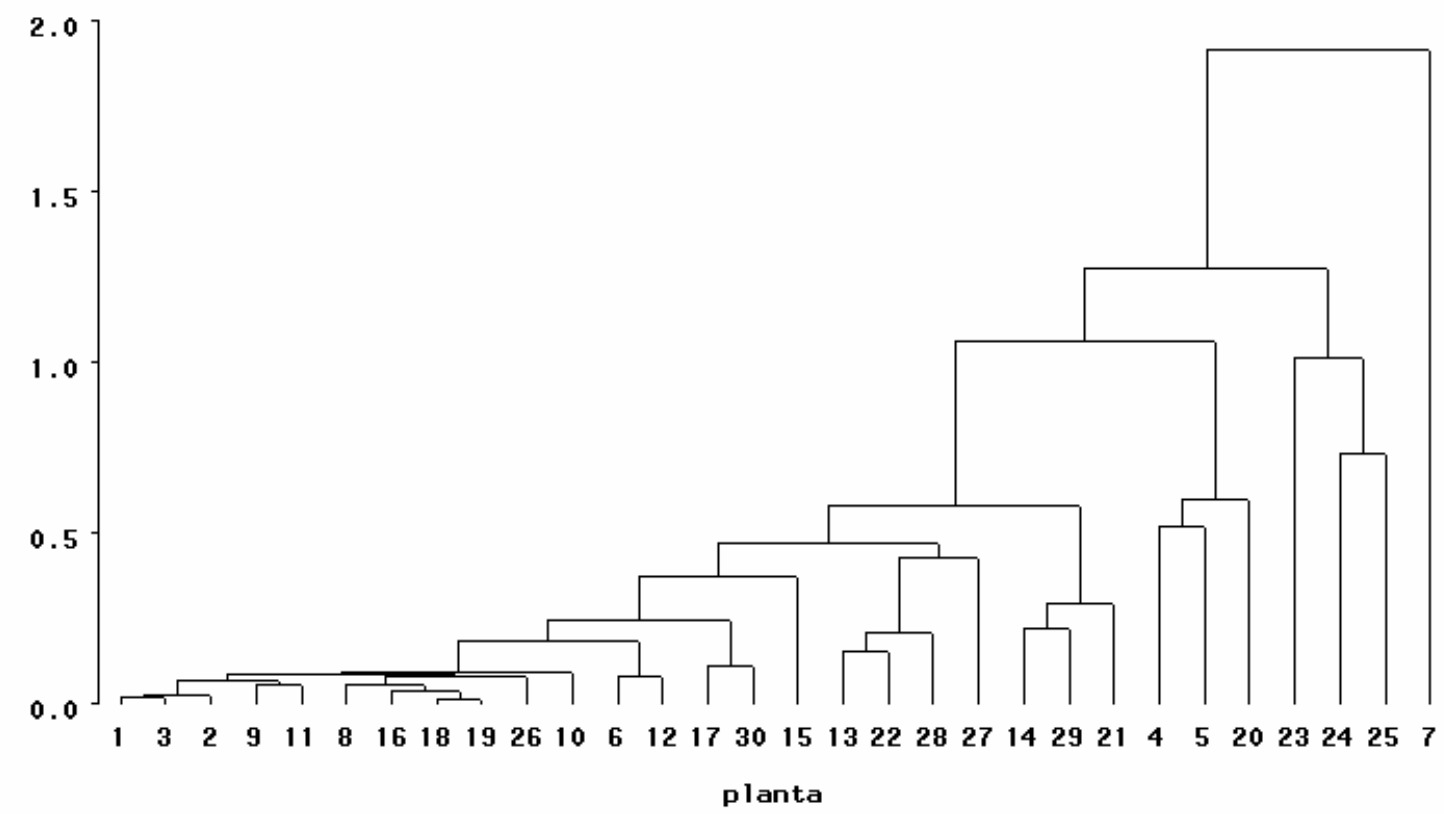

Figura 10 - Resultado dos agrupamentos entre partes em função do perfil de n-alcanos

A composição de cada grupo está descrita no Quadro 2. Cada grupo foi definido considerando-se as maiores distâncias entre grupos pois espécies com perfis muito próximos não podem ser diferenciadas pelo modelo "EatWhat" (Dove \& Moore, 1996) utilizado para estimar a composição botânica da dieta. 


\begin{tabular}{|c|c|c|c|}
\hline Grupo & Planta & Espécies & Parte ingerida \\
\hline Gr 1 & 7 & Calliandra dysantha & Flor \\
\hline \multirow[t]{2}{*}{ Gr 2} & 24 & Zea mays & Broto \\
\hline & 25 & Zea mays & Folha \\
\hline Gr 3 & 23 & Brachiaria decumbens & Semente \\
\hline Gr 4 & 20 & Mimosa cf. xanthocentra & Flor \\
\hline \multirow[t]{2}{*}{ Gr 5} & 4 & Bauhinia holophylla & botão floral \\
\hline & 5 & Bauhinia holophylla & Flor \\
\hline \multirow[t]{3}{*}{ Gr 6} & 14 & Calea sp. & Flor \\
\hline & 21 & Manihot gracilis & Broto \\
\hline & 29 & Sorghum bicolor & Folha \\
\hline Gr 7 & 28 & Glycine hispida & Fruto \\
\hline \multirow[t]{3}{*}{ Gr 8} & 13 & Smilax sp. & Broto \\
\hline & 22 & Euphorbia heterophylla & Broto \\
\hline & 28 & Glycine hispida & Folha \\
\hline Gr 9 & 15 & Syagrus petraea & Fruto \\
\hline \multirow[t]{2}{*}{ Gr 10} & 17 & Mimosa cf. xanthocentra & Folha \\
\hline & 30 & Sorghum bicolor & Grão \\
\hline \multirow[t]{2}{*}{ Gr 11} & 6 & Portulaca oleracea & Broto \\
\hline & 12 & Serjania lethalis & Folha \\
\hline \multirow[t]{11}{*}{ Gr 12} & 1 & Annona warmingiana & Fruto \\
\hline & 2 & Stryphnodendron adstringens & Broto \\
\hline & 3 & Stryphnodendron adstringens & Fruto \\
\hline & 8 & Anadenanthera sp. & Broto \\
\hline & 9 & Solanum lycocarpum & Fruto \\
\hline & 10 & Solanum lycocarpum & Casca \\
\hline & 11 & Solanum lycocarpum & Polpa \\
\hline & 16 & Mimosa cf. xanthocentra & Broto \\
\hline & 18 & Mimosa cf. xanthocentra & Fruto \\
\hline & 19 & Mimosa cf. xanthocentra & fruto + semente \\
\hline & 26 & Glycine hispida & Broto \\
\hline
\end{tabular}

Quadro 2 - Composição botânica dos 12 grupos agrupados em função do perfil de n-alcanos 
Para estimar a composição botânica da dieta foram considerados 12 n-alcanos $\left(\mathrm{C}_{22} \mathrm{a}_{33}\right)$ dos perfis das fezes, confrontados com os perfis de 12 grupos de plantas. Os resultados obtidos através do modelo "EatWhat" estão descritos nas Tabelas 18 e 19, e graficamente nas Figuras 11 e 12.

Tabela 18. Contribuição percentual dos grupos nas coletas do interior do PNE

\begin{tabular}{ccccccccccccc}
\hline \multicolumn{110}{c}{ Grupos } \\
& Gr1 & Gr2 & Gr3 & Gr4 & Gr5 & Gr6 & Gr7 & Gr8 & Gr9 & Gr10 & Gr11 & Gr12 \\
\hline jul/03 & 8,0 & 0,9 & 0,0 & 0,7 & 0,0 & 12,5 & 0,0 & 37,0 & 3,6 & 0,0 & 15,2 & 22,3 \\
set/03 & 2,3 & 0,5 & 0,0 & 0,0 & 0,0 & 1,8 & 0,0 & 34,0 & 0,0 & 0,0 & 61,2 & 0,0 \\
nov/03 & 12,2 & 0,0 & 0,0 & 0,0 & 0,0 & 0,6 & 0,0 & 0,7 & 0,0 & 5,2 & 81,3 & 0,0 \\
jan/04 & 2,2 & 0,0 & 1,0 & 1,8 & 0,0 & 20,3 & 0,0 & 22,5 & 0,0 & 24,9 & 26,8 & 0,5 \\
mar/04 & 10,0 & 0,0 & 1,0 & 0,0 & 0,0 & 25,0 & 0,0 & 0,0 & 0,0 & 30,0 & 34,0 & 0,0 \\
mai/04 & 1,3 & 3,3 & 0,1 & 0,0 & 0,0 & 11,8 & 0,0 & 0,0 & 0,0 & 14,2 & 62,7 & 6,6 \\
inverno & 3,9 & 1,6 & 0,0 & 0,2 & 0,0 & 8,7 & 0,0 & 23,7 & 1,2 & 4,7 & 46,4 & 9,6 \\
verão & 8,1 & 0,0 & 0,7 & 0,6 & 0,0 & 15,3 & 0,0 & 7,7 & 0,0 & 20,0 & 47,4 & 0,2 \\
\hline Inverno: jul/03+ set/03+ mai/04; & & & & & & & & &
\end{tabular}

Tabela 19. Contribuição percentual dos grupos nas coletas do perímetro do PNE

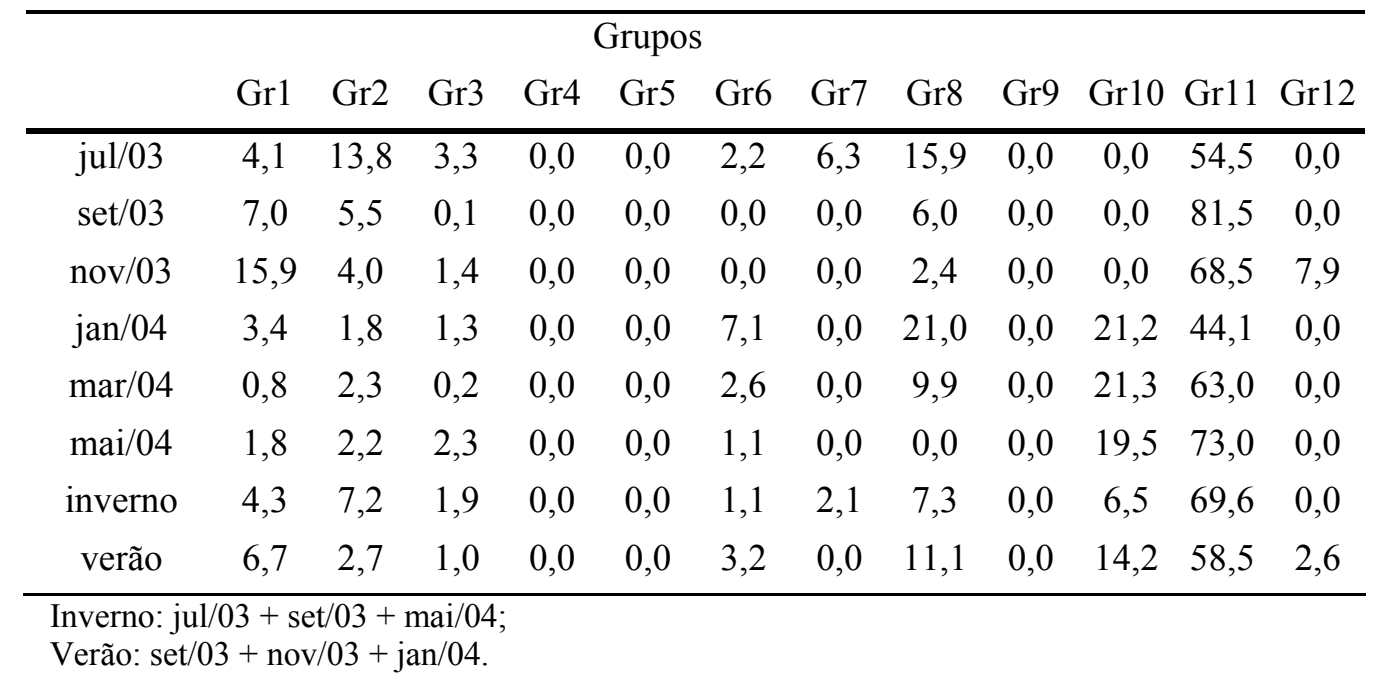




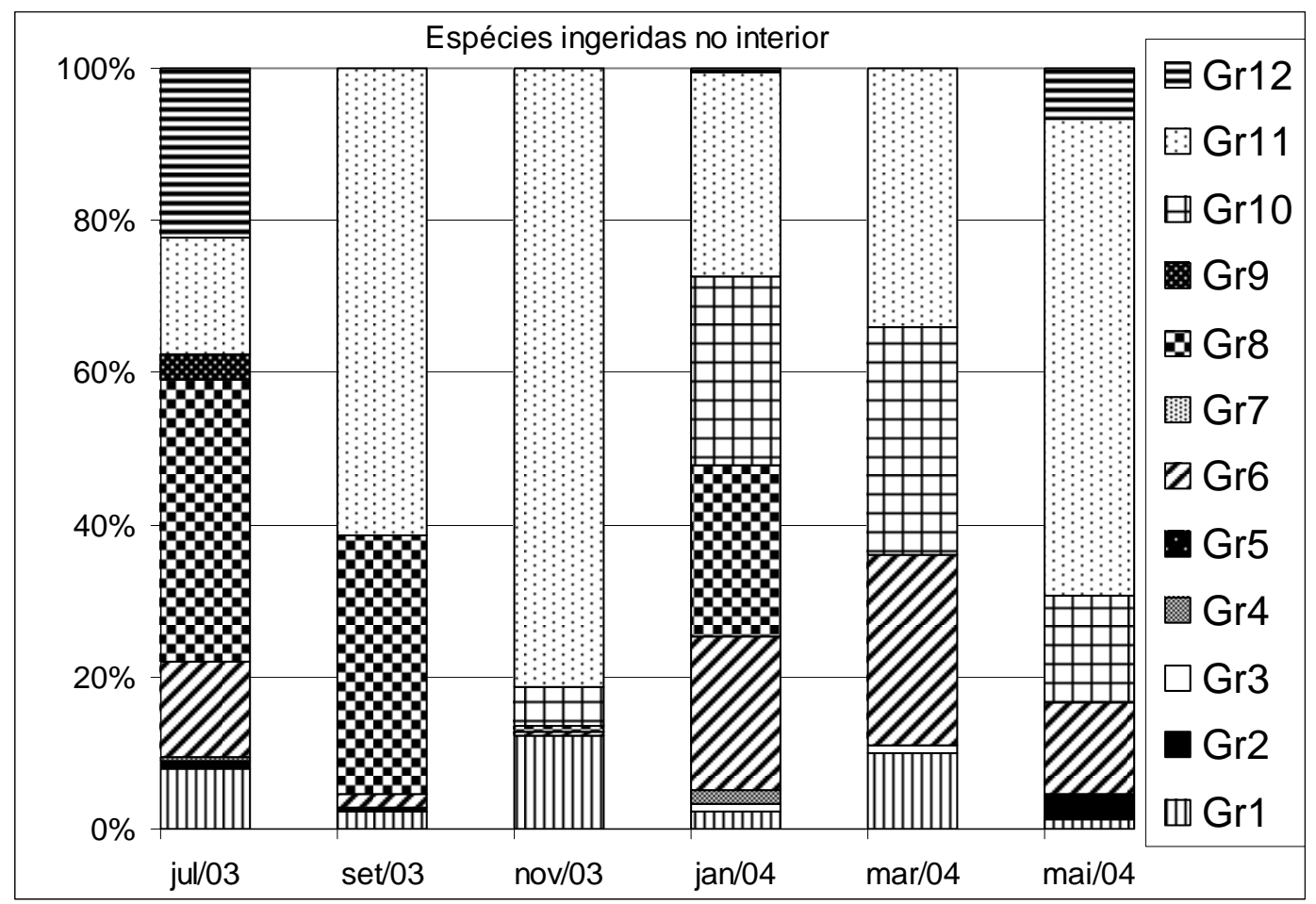

Figura 11 - Contribuição percentual dos grupos nas coletas do perímetro do PNE

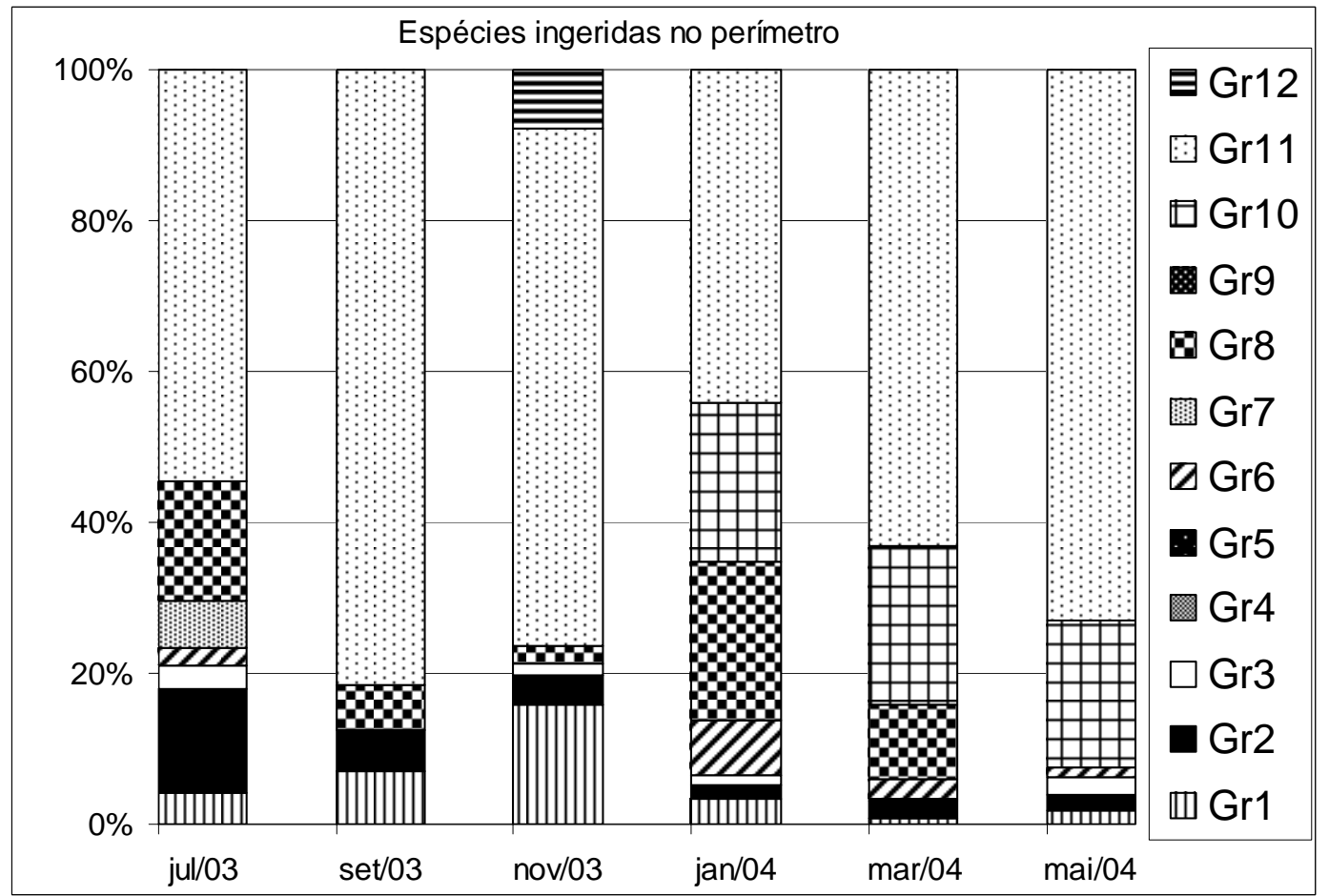

Figura 12 - Contribuição percentual dos grupos nas coletas do perímetro do PNE 
Embora tenham sido identificadas diferenças entre as contribuições percentuais dos grupos preferencialmente ingeridos no interior e no perímetro do PNE podemos observar que os grupos mais ingeridos são semelhantes nas duas áreas, especialmente os grupos 8,10 e 11, perfazendo mais de $70 \%$ da dieta. A contribuição do grupo 2 (folha e broto de milho) foi significativamente maior nas amostras coletadas no perímetro mas não era esperado encontrar este grupo nas amostras do interior. Esta pode ser uma imperfeição do modelo pois este grupo pode ter sido considerado apenas devido à semelhança de perfil com outras plantas.

Para evitar a sobreposição de grupos ou espécies que sabidamente não poderiam compor a dieta dos animais do interior do parque um novo modelo foi testado, retirando as culturas agrícolas das estimativas de composição da dieta dos animais do interior do PNE.

As plantas foram novamente agrupadas em relação aos perfis de n-alcanos, utilizando-se as 19 partes vegetais mais ingeridas representando as 12 principais espécies nativas vegetais selecionadas pelos animais no interior. $\mathrm{O}$ resultado dos agrupamentos está na Figura 13.

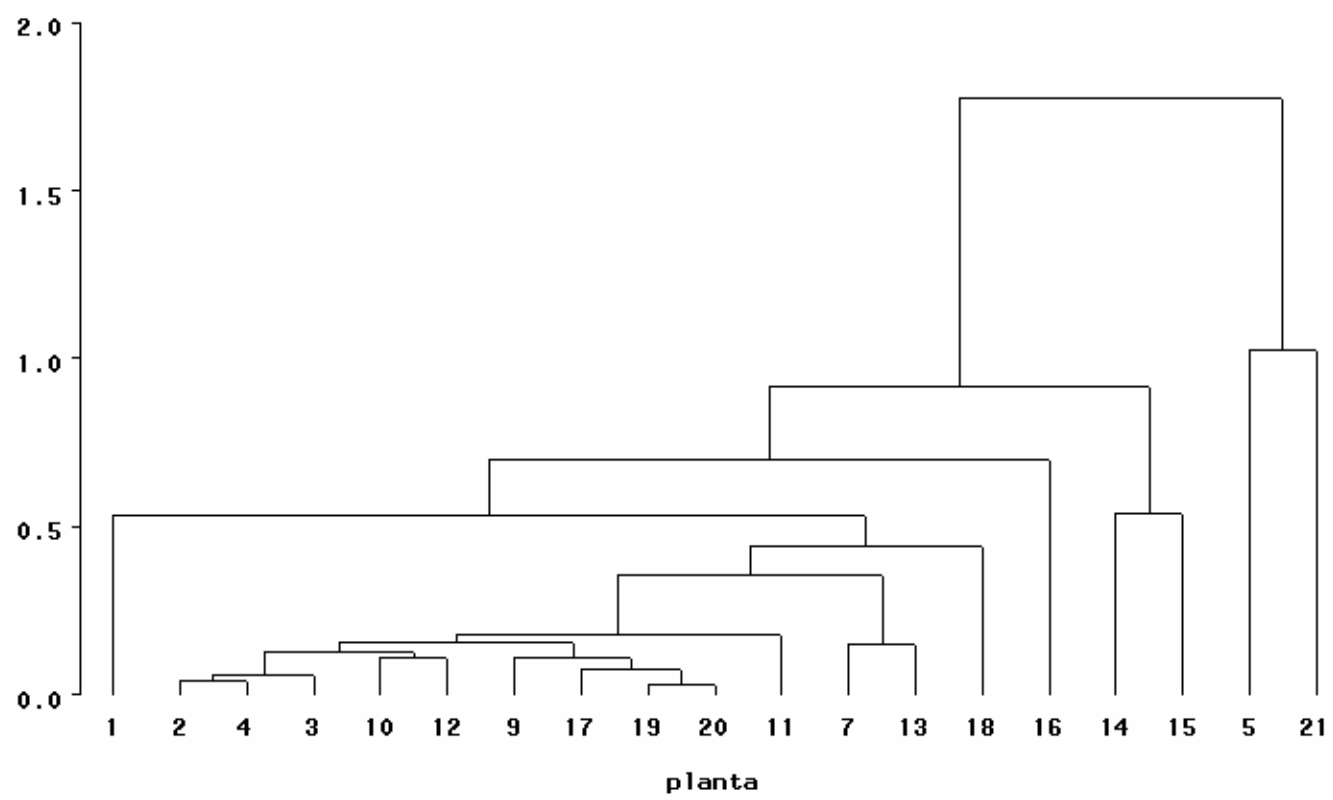

Figura 13 - Resultado dos agrupamentos entre partes em função do perfil de n-alcanos (excluindo culturas agrícolas) 
O novo agrupamento foi definido em 8 grupos cuja composição está descrita no Quadro 3.

\begin{tabular}{|cccc|}
\hline Grupo & Planta & Espécies & Parte ingerida \\
\hline Gr 1 & 5 & Bauhinia holophylla & flor \\
& 21 & Manihot gracilis & broto \\
Gr 2 & 14 & Calea sp. & flor \\
& 15 & Syagrus petraea & fruto \\
Gr 3 & 16 & Mimosa cf. xanthocentra & broto \\
Gr 4 & 1 & Annona warmingiana & fruto \\
Gr 5 & 18 & Mimosa cf. xanthocentra & fruto \\
Gr 6 & 7 & Calliandra dysantha & flor \\
& 13 & Smilax sp. & broto \\
Gr 7 & 11 & Solanum lycocarpum & polpa \\
Gr 8 & 19 & Mimosa cf. xanthocentra & fruto + semente \\
& 20 & Mimosa cf. xanthocentra & flor \\
& 17 & Mimosa cf. xanthocentra & folha \\
& 9 & Solanum lycocarpum & fruto \\
& 10 & Solanum lycocarpum & casca \\
& 12 & Serjania lethalis & broto \\
& 2 & Stryphnodendron adstringens & broto \\
& 3 & Stryphnodendron adstringens & fruto \\
& 4 & Bauhinia holophylla & botão floral \\
\hline
\end{tabular}

Quadro 3 - Composição botânica dos 8 grupos agrupados em função do perfil de n-alcanos

Para estimar a composição botânica da dieta foram considerados 12 n-alcanos $\left(\mathrm{C}_{22}\right.$ a $\left.\mathrm{C}_{33}\right)$ dos perfis das fezes, confrontados com os perfis dos 8 grupos de plantas. Os resultados obtidos através do modelo "EatWhat" estão descritos na Tabela $20 \mathrm{e}$ graficamente na Figura 14. 
Tabela 20. Contribuição percentual dos grupos nas coletas do interior do PNE, excluindo as culturas agrícolas

\begin{tabular}{ccccccccc}
\hline & \multicolumn{7}{c}{ Grupos } \\
& Gr1 & Gr2 & Gr3 & Gr4 & Gr5 & Gr6 & Gr7 & Gr8 \\
\hline jul/03 & 0,0 & 56,3 & 0,0 & 0,0 & 0,0 & 43,8 & 0,0 & 0,0 \\
set/03 & 0,0 & 74,4 & 0,0 & 0,0 & 0,0 & 25,6 & 0,0 & 0,0 \\
nov/03 & 0,0 & 5,6 & 0,0 & 2,2 & 0,0 & 86,9 & 5,3 & 0,0 \\
jan/04 & 1,3 & 46,8 & 0,0 & 3,4 & 0,0 & 15,6 & 33,0 & 0,0 \\
mar/04 & 5,9 & 36,8 & 4,9 & 6,8 & 0,0 & 35,0 & 10,6 & 0,0 \\
mai/04 & 0,0 & 32,1 & 0,0 & 35,3 & 0,0 & 13,2 & 19,4 & 0,0 \\
inverno & 0,0 & 54,2 & 0,0 & 11,8 & 0,0 & 27,5 & 6,5 & 0,0 \\
verão & 2,4 & 29,7 & 1,6 & 4,1 & 0,0 & 45,8 & 16,3 & 0,0 \\
\hline
\end{tabular}

Inverno: jul/03 + set/03 + mai/04;

Verão: set/03+ nov/03 + jan/04.

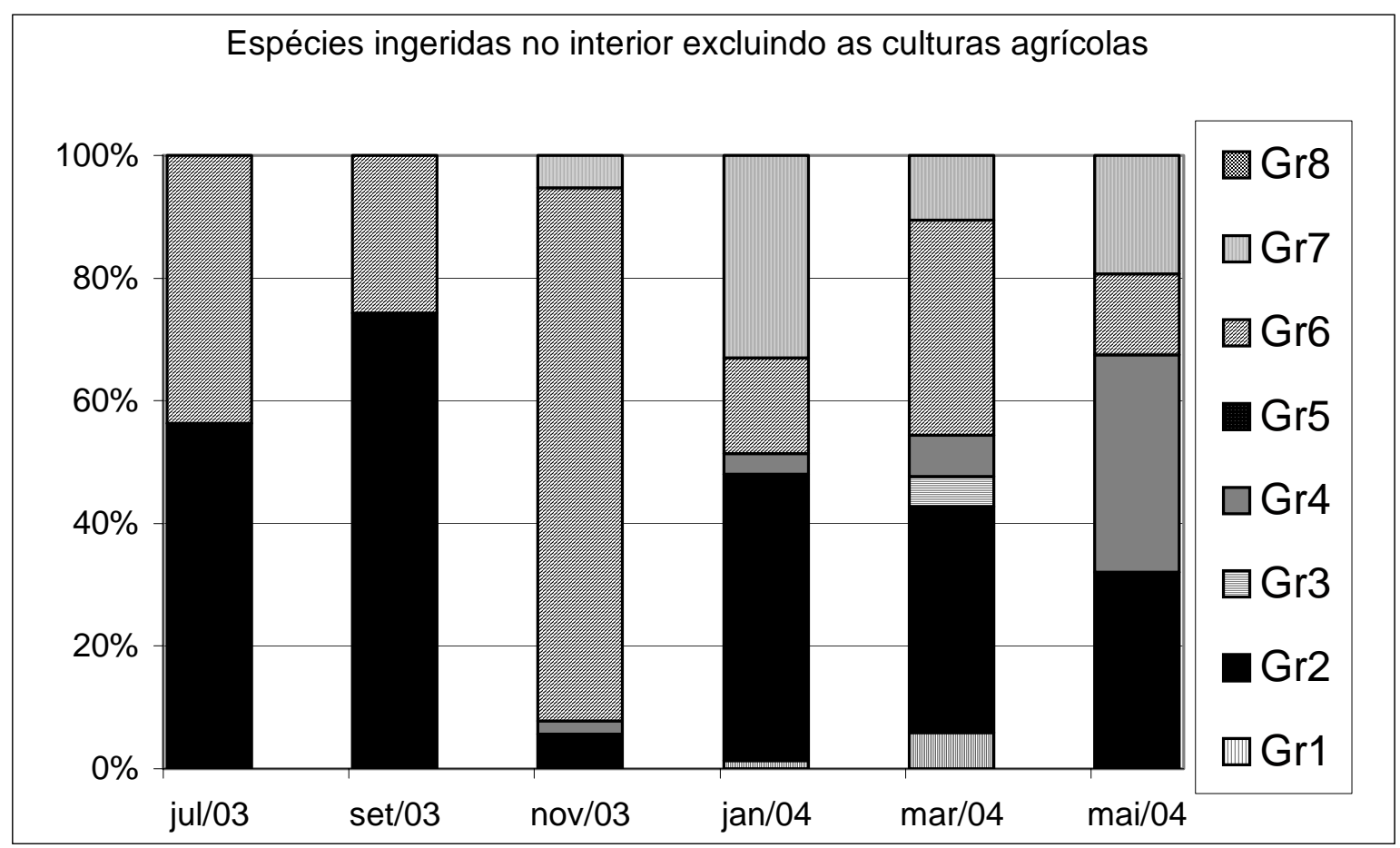

Figura 14 - Contribuição percentual dos grupos nas coletas do interior do PNE, excluindo as culturas agrícolas 
Segundo os resultados obtidos através do modelo que excluiu as culturas agrícolas do conjunto de espécies disponíveis no interior do PNE, os grupos mais ingeridos foram os de números 2, 4, 6 e 7.

Uma expectativa com relação à técnica de n-alcanos para estimativa da composição botânica da dieta do veado-campeiro era de que, a partir da "biblioteca" de plantas disponíveis e ingeridas ao longo do ano, fosse possível caracterizar a dieta exclusivamente comparando-se os perfis das plantas com as fezes. Considerando a totalidade de espécies vegetais disponíveis aos animais e seus respectivos perfis de nalcanos, que constituem a "biblioteca" da oferta de alimento, não foi possível identificar direta e precisamente a contribuição das espécies ingeridas através do perfil de n-alcanos das fezes. Para uma análise mais próxima ao efetivamente observado no PNE foi preciso excluir algumas espécies que sabidamente não poderiam compor a dieta dos animais no interior do parque, comprometendo a exclusividade da técnica de n-alcanos.

Ao utilizarmos outras técnicas e o conhecimento prévio das espécies efetivamente consumidas, a técnica de n-alcanos mostrou-se eficaz na quantificação dos grupos ingeridos ao longo do ano, aproximando-se ao observado visualmente no parque.

\subsection{Conclusões}

A dieta do veado-campeiro no Parque Nacional das Emas é muito variada, composta por aproximadamente 78 itens provenientes de 55 espécies nativas e de 7 culturas agrícolas.

O veado-campeiro apresenta comportamento típico de "browser" ou selecionador de concentrados, alimentando-se de brotos (38,5\%), folhas (15,4\%), flores $(17,9 \%)$, botões florais $(12,8 \%)$, frutos e sementes $(15,4 \%)$. Os grupos de plantas preferencialmente consumidos pelo veado-campeiro variaram ao longo do ano e contribuíram de forma diferente para a dieta dos animais.

Os veados-campeiro que vivem na periferia do Parque Nacional das Emas utilizam as espécies agrícolas cultivadas no entorno como fonte de alimento, contribuindo com até $46,9 \%$ da dieta total. 
A técnica de n-alcanos pode ser utilizada para caracterização botânica da dieta do veado-campeiro mas sua acurácia é dependente dos perfis das diferentes espécies vegetais que compõem esta dieta. O uso de técnicas complementares à de n-alcanos, como os sinais isotópicos do carbono 13 e um prévio conhecimento das espécies ingeridas pelos veados-campeiro, podem auxiliar na caracterização da dieta. 


\section{CONCLUSÕES GERAIS}

A dieta peletizada desenvolvida para o experimento em cativeiro atendeu às exigências nutricionais do veado-catingueiro (Mazama gouazoubira) e pode ser utilizada para manutenção desta espécie em cativeiro.

A exigência de energia para mantença do veado catingueiro em cativeiro foi determinada através do método da água duplamente marcada, obtendo valor médio de $112,0 \pm 29,2 \mathrm{kcal} / \mathrm{kg}^{0,75}$.d. Este valor estimado foi validado através da medição nos mesmos animais pelo método padrão (de equilíbrio de peso). Apesar da variação entre indivíduos a técnica da água duplamente marcada é um método não invasivo com grande potencial para determinar a demanda de energia de animais em vida livre. Com enriquecimento semelhante ao do experimento em cativeiro, 111,8 $\mathrm{mg} / \mathrm{kgPV}$ de ${ }^{2} \mathrm{H}_{2} \mathrm{O}$ e $163,1 \mathrm{mg} / \mathrm{kgPV}$ de $\mathrm{H}_{2}{ }^{18} \mathrm{O}$, a coleta de sangue final poderá ser realizada até 30 dias após a aplicação, permitindo o uso em vida livre.

A dieta do veado-campeiro (Ozotoceros bezoarticus) no Parque Nacional das Emas é muito variada, composta por aproximadamente 78 itens provenientes de 55 espécies nativas e de 7 culturas agrícolas.

O veado-campeiro apresenta comportamento típico de "browser" ou selecionador de concentrados, alimentando-se de brotos $(38,5 \%)$, folhas $(15,4 \%)$, flores $(17,9 \%)$, botões florais $(12,8 \%)$, frutos e sementes $(15,4 \%)$. Os grupos de plantas preferencialmente consumidos pelo veado-campeiro variaram ao longo do ano e contribuíram de forma diferente para a dieta dos animais.

Os veados-campeiro que vivem na periferia do Parque Nacional das Emas utilizam as espécies agrícolas cultivadas no entorno como fonte de alimento, contribuindo com até $46,9 \%$ da dieta total. 
A técnica de n-alcanos pode ser utilizada para caracterização botânica da dieta do veado-campeiro mas sua acurácia é dependente dos perfis das diferentes espécies vegetais que compõem esta dieta. $\mathrm{O}$ uso de técnicas complementares à de n-alcanos, como os sinais isotópicos do carbono 13 e um prévio conhecimento das espécies ingeridas pelos veados-campeiro, podem auxiliar na caracterização da dieta. 


\section{REFERÊNCIAS BIBLIOGRÁFICAS}

ADAMCZEWSKI, J.Z.; HUDSON, R.J.; GATES, C.C. et al. Winter energy balance and activity of female caribou on Coats Island, Northwest Territories: The relative importance of foraging and body reserves. Canadian Journal of Zoology, v.71, p.1221-1229. 1993.

BARBOSA, J. Validação do uso de n-alcanos como indicadores para estudos nutricionais em veados-catingueiro (Mazama gouazoubira). Piracicaba, 2003. 64p. Dissertação (Mestrado) - Escola Superior de Agricultura "Luiz de Queiroz", Universidade de São Paulo.

BARBOSA, J.; BERNDT, A.; OLIVEIRA, D.E. de et al. Nutrient digestibility in grey brocket deer (Mazama gouazoubira) by total fecal collection. In: INTERNATIONAL DEER BIOLOGY CONGRESS, 3., Quebec, 2002. Proceedings. Quebec City, 2002a. p. 29.

BARBOSA, J.; OLIVEIRA, D.E de; BERNDT, A. et al. Digestibility estimated with n-alkanes in grey brocket deer (Mazama gouazoubira). In: INTERNATIONAL DEER BIOLOGY CONGRESS, 3., Quebec, 2002. Proceedings. Quebec City, 2002b. p. 30.

BATALHA, M.A.P.L. Florística, espectro biológico e padrões fenológicos do cerrado sensu lato no Parque Nacional das Emas (GO) e o componente herbáceosubarbustivo da flora do cerrado sensu lato. Campinas, 2001. Tese (Doutorado) Instituto de Biologia, Universidade Estadual de Campinas.

BATALHA, M.A.P.L.; MARTINS, F. R. The vascular flora of the cerrado in Emas National Park (central Brazil). Sida, Contributions to Botany, v.20, p.295-312, 2002.

BERGMAN, C.M.; FRYXELL, J.M.; GATES, C. et al. Ungulate foraging strategies: energy maximizing or time minimizing? Journal of Animal Ecology, v.70, p.289-300, 2001. 
BLAXTER, K.L. Energy metabolism. In. SYMPOSIUM OF THE EUROPEAN ASSOCIATION FOR ANIMAL PRODUCTION, 3., Edinburgh, 1965. Proceedings. Edinburgh: EAAP, 1965. p. 441-443.

BOADI, D.A.; MOSHTAGHI, S.A.; WITTENBERG, K.M. et al. The n-alkane profile of some native and cultivated forages in Canada. Canadian Journal of Animal Science, v.82, p. 465-469, 2002.

BODMER, R.E. Frugivory in Amazonian Artiodactyla: Evidence for the evolution of the ruminant stomach. Journal of Zoology, v.219, p.457-467, 1989.

BODMER, R.E. Responses of ungulates to seasonal inundations in the amazon floodplain. Journal of Tropical Ecology, v.6, p.191-201, 1990.

BRAGA, F. Pampas deer survey in Paraná State, Brasil . Deer Specialist Group News, v.15, p. 11, 1999.

BRAGA, F.G. Nuevas ocorrencias de Venado de Campo, Ozotoceros bezoarticus em el Estado del Paraná, Sur del Brasil. Deer Specialist Group News, v.17, p. 3, 2002.

BRAGA, F.G.; MOURA-BRITO, M.; MARGARIDO, T.C.C. Estudo de uma população relictual de Veado_Campeiro, Ozotoceros bezoarticus, (Linnaeus) (Artiodactyla, Cervidae) no município da Lapa, Paraná, Brasil. Revista Brasileira de Zoologia, v.17, n.1, p.175-181, 2000.

BRANAN, W.V.; WERKHOVEN, M.C.M.; MARCHINTON, R.L. Food habits of brocket and white-tailed deer in Suriname. Journal of Wildlife Management, v.49, p.972-976, 1985.

BROWER, E. Report of sub-comittes on constants and factors. In: SYMPOSIUM OF THE EUROPEAN ASSOCIATION FOR ANIMAL PRODUCTION, 3., Edinburgh, 1965. Proceedings. Edinburgh: EAAP, 1965. p. 441-443.

BROWN, R.D. Deer nutrition. Overton Deer Farming Seminar. Texas Agricultural Experiment Station, v.95, n.2, p.1-8, 1995.

BRUCKENTAL, I.; HALEVI, A.; AMIR, S. et al. The ratio of naturally occurring ${ }^{13} \mathrm{C}$ and ${ }^{12} \mathrm{C}$ isotopes in sheep diet and faeces as a measurement for direct determination of lucerne hay and maize grain digestibilities in mixed diets. Journal of Agricultural Science, v.104, p.271-274, 1985.

CHURCH, D.C. The ruminant animal, digestive physiology and nutrition. Illinois: Waveland Press, 1993. 564p. 
COOK, J.G.; IRWIN, L.L.; BRYANT, L.D. et al. Relations of forest cover and condition of elk: A test of the thermal cover hypothesis in summer and winter. Wildlife Monographs, v.141, p.1-61, 1998.

DEBBRECHT, F.J. Qualitative and quantitative analysis by gas chromatography. In: GROB, R.L. (Ed). Modern practice of gas chromatography. New York: Wiley Interscience, 1985. p. 359-421.

DELGIUDICE, G.D.; KERR, K.D.; MECH, L.D. et al. Prolonged winter undernutrition and the interpretation of urinary allantoin:creatinine ratios in white-tailed deer. Canadian Journal of Zoology, v.78, p. 2147-2155, 2000.

DEMMENT, M.W.; VAN SOEST, P.J. A nutritional explanation of body-size patterns of ruminant and nonruminant herbivores. American Naturalist, v.125, p.641-672, 1985.

DILLON, P.; STAKELUM, G. The analysis of n-alkanes in faeces and herbage. In: EUROPEAN GRAZING WORKSHOP, 7., Wageningen, 1990. Proceedings. Wageninger: Ed Institute voor Veevoedingsoderzoek, 1990. 1v.

DOVE, H.; MAYES, R.W. The use of plant wax alkanes as marker substances in studies of the nutrition of herbivores: a review. Australian Journal of Agricultural Research, v.42, p.913-952, 1991.

DOVE, H.; MOORE, A.D. Using a least-squares optimisation procedure to estimate botanical composition based on the alkanes of plant cuticular wax. Australian Journal of Agricultural Research, v.46, p.1535-1544, 1996.

DOVE, H.; MAYES, R.W.; FREER, M. Effect of species, plant part, and plant age on the n-alkane profile concentrations in the cuticular wax of pasture plants. Australian Journal of Agricultural Research, v.47, p.1333-1347, 1996.

DUARTE, J.M.B. Biologia e conservação de cervídeos sul-americanos: Blastocerus, Ozotoceros e Mazama. Jaboticabal: FUNEP, 1997. 238 p.

EISENBERG, J.F.; REDFORD, K.H. Mammals of the neotropics. Chicago: The University of Chicago Press, 1999. v. 3, 609 p.

FANCY, S.G.; BLANCHARD, J.M.; HOLLEMAN, D.F. et al. Validation of doubly labeled water method using a ruminant. American Journal of Physiology, v.251, p.143-149, 1986. 
FRUTUOSO, N.G. Uso de sistema de informações geográficas na análise de distribuição do veado-campeiro (Ozotoceros bezoarticus) no Parque Nacional das Emas, Goiás. Piracicaba, 1999. 73 p. Dissertação (Mestrado) - Escola Superior de Agricultura "Luiz de Queiroz", Universidade de São Paulo.

GEDIR, J.V.; HUDSON, R.J. Estimating dry matter digestibility and intake in wapiti (Cervus elaphus canadensis) using the double n-alkane ratio technique. Small Ruminant Research, v.36, p.57-62, 2000.

GEIST, V. Elk country. Minocqua: North World Press, 1991. 176 p.

GOTAAS, G.; MILNE, E.; HAGGARTY, P. et al. Energy expenditure of free-living reindeer estimated by the doubly labelled water method. Rangifer, v.20, p.211219, 2000a.

GOTAAS, G.; MILNE, E.; HAGGARTY, P. et al. Loss of deuterium in faecal solids and by sequestration in reindeer: effect on doubly labelled water studies. Rangifer, v.20, p.31-41, 2000b.

GRACE, N.D.;BODY, D.R. The possible use of long chain $\left(\mathrm{C}_{19}-\mathrm{C}_{32}\right)$ fatty acids in herbage as na indigestible faecal marker. Journal of Agricultural Science, v.97, n.3, p.743-745, 1981.

HAGGARTY, P. Review: potencial of the doubly labelled water method for estimating heat production in farm animals. Journal of Agricultural Science, v.117, p.141-148, 1991.

HAGGARTY, P.; ROBINSON, J.J., ASHTON, J. et al. Estimation of energy expenditure in free-living red deer (Cervus elaphus) with the double labelled water method. British Journal of Nutrition, v.80, p.263-272, 1998.

HAIGH, J.C.; HUDSON, R.J. Farming wapiti and red deer. St. Louis: Mosby, 1993. $369 \mathrm{p}$.

HATT, J.M.; DOLL, M.L.; MAYES, B. The use of dosed and herbage n-alkanes as markers for the determination of digestive strategies of captive giraffes. Zoo Biology, v.17, p.295-309, 1998.

HAWKE, J.C.; BUTLER, G.W.; BAILEY, R.W. Chemistry and biochemistry of herbage. London: Academic Press, 1973. v. 1, p. 213-263. 
HOLLEMAN, D.F.; WHITE, R.G.; LUICK, J.R. Application of the isotopic water method for measuring total body water, body composition and body water turnover. In: Use of tritiated water in studies of production and adaptation in ruminants. INTERNATIONAL ATOMIC ENERGY AGENCY, Vienna, 1982. p. 9-32.

HOLTER,J.B.;HAYES,H.H.; SMITH,S.H. Protein requirement of yearling whitetailed deer. Journal of Wildlife Management, v. 43, p. 872-879, 1979.

INSTITUTO BRASILEIRO DE MEIO AMBIENTE. Lista oficial de espécies da fauna brasileira ameaçada de extinção. Portaria 1.522, de 19 de dezembro de 1989. Brasília, 1989.

JACKSON, J.E.; GIULIETTI, J.D. The food habits of pampas deer Ozotoceros bezoarticus celer in relation to its conservation in a relict natural grassland in Argentina. Biological Conservation, v. 45, p. 1-10, 1988.

JACKSON, J.E.; LANGGUTH, A. Ecology and status of pampas deer in the argentinian pampas and Uruguay. In: WEMMER, C.M.(Ed). Biology and management of Cervidae. Washington: Smithsonian Institution Press, 1987. p. 402-409.

JENSEN, P.G.; PEKINS, P.J.; HOLTER, J.B. Compensatory effect of the heat increment of feeding on thermoregulation costs of white-tailed fawns in winter. Canadian Journal of Zoology, v. 77, p. 1474-1485, 1999.

JONES, R.J.; LUDLOW, M..M.; TROUGHTON, J.H. et al Estimation of the proportion of $\mathrm{C} 3$ and $\mathrm{C} 4$ plant species in the diet of animals from the ratio of natural ${ }^{12} \mathrm{C}$ and ${ }^{13} \mathrm{C}$ isotopes in the faeces. Journal of Agricultural Science, v. 92, p. 91-100, 1979.

LANNA, D.P.D., BOIN, C. Estimativa da composição química de ruminantes através de práticas de diluição de isótopos. In: CONGRESSO BRASILEIRO DE INICIAÇÃO CIENTÍFICA EM CIÊNCIAS AGRÁRIAS, 5., Lavras, 1985. Anais. Lavras:UFLA, 1985. p. 25.

LANNA, D.P.D.; LEME, P.R.; HENRIQUE, W. et al. Substitution of starch for pectin for crossbred zebu bulls: metabolizable and net energy requirements and efficiency of energy utilization. Journal of Animal Science, v.75, n.1, p.274, 1997. 
LEME, P.R.; BOIN, C.; ALLEONI, G.F. et al. Estimativa da composição química corporal de novilhos nelore através do espaço de deutério. Revista da Sociedade Brasileira de Zootecnia, v. 23, n. 3, p. 441-452, 1994.

LIFSON, N.; GORDON,G.B.; McCLINTOCK, R. Measurement of total carbon dioxide production by means of $\mathrm{D}_{2}{ }^{18} \mathrm{O}$. Journal of Applied Physiology, v. 7, p. 704-710, 1955.

LOFGREEN,G.P.; GARRETT, W.N. A system for expressing energy requirements and feed values for growing and finishing beef cattle. Journal of Animal Science, v.27, n.3, p.793 - 806, 1968.

LOURENÇO, A.J.; MATSUI, E.; ARCARO JÚNIOR, I. Variações de valores de $\delta^{13} \mathrm{C}$ nas fezes, leite e sangue de vacas em lactação mantidas em pastagens exclusivas de gramíneas ou consorciadas. Boletim da Indústria Animal, v.41, p.183-192, 1984.

MAYES,R.W.; DOVE, H. Measurement of dietary nutrient intake in free-ranging mammalian herbivores. Nutrition Research Reviews, v.13, p.107-138, 2000.

MAYES, R.W.; LAMB, C.S. The possible use of $n$-alkanes in herbage as indigestible faecal markers. Proceedings of Nutrition Society, v. 43, n. 1-3, p. 39, 1984.

MAYES, R.W.; LAMB, C.S.; COLGROVE, P.M. The use of dosed and herbage nalkanes as markers for the determination of herbage intake. Journal of Agricultural Science, v. 107, p. 161-170, 1986.

Mc NAIR, L.A.; BONNELI, K. Basic chromatography. 4. Palo Alto: Varian Instrument Division Offices, 1968, 167p.

MERINO, M.L.; CARPINETTI, B.N. Pampas deer population trend in Bahia Samborombón, Buenos Aires Province, Argentina. Deer Specialist Group News, v.14, p.10-11, 1998.

MIDWOOD, A.J.; HAGGARTY, B.A. Validation in sheep of the doubly labelled water method for estimating $\mathrm{CO}_{2}$ production. American Journal of Physiology, v. 266, p. 169-179, 1994.

MIDWOOD, A.J.; HAGGARTY, B.A.; McGAW, G.S. et al. Methane production in ruminants: it's effect on the doubly labelled water. American Journal of Physiology, v.257, p.1488-1495, 1989. 
MIDWOOD, A.J.; HAGGARTY, B.A.; McGAW, G.S. et al. The doubly labelled water method: Errors due to deuterium exchange and sequestration in ruminants. American Journal of Physiology, v.264, p.561-567, 1993.

MINSON, D.J.; LUDLOW, M.M.; TROUGHTON, J.H. Differences in natural carbon isotope ratios of milk and hair from cattle grazing tropical and temperate pastures. Nature, v.256, p.602, 1975.

MORRISON, R.; BOYD, R.N. Organic chemistry. Boston: Calouste Gulbenkian Foundation, 1972. cap. 4, p. 110-172: Alcanes.

NAGY, K.A. $\mathrm{CO}_{2}$ production in animals: analysis of potential errors in the doubly labeled water method. American Journal of Physiology, v. 238, p. 466-473, 1980.

NIA, S.A.M.; WITTENBERG, K.M. Evaluation of n-alkanes as markers for estimation of dry matter intake and digestibility in steers consuming allforage or forage-concentrate diets. Canadian Journal of Animal Science, v. 82, p. 419-425, 2002.

OLIVEIRA, D.E. Digestibilidade pelo método indireto usando n-alcanos. Porto Alegre, 1995. 92 p. Dissertação (Mestrado) - Faculdade de Agronomia, Universidade Federal do Rio Grande do Sul.

OLIVEIRA, D.E. Determinação de alcanos: manual de extração e análise cromatográfica em forragens, concentrados e fezes. Piracicaba: FEALQ, 2004. $30 \mathrm{p}$.

OLIVEIRA, D.E.; PRATES, E.R.; PERALBA, M.C.R. Identificação e quantificação de n-alcanos presentes nas ceras de plantas forrageiras. Revista Brasileira de Zootecnia, v.26, n.5, p. 881-886, 1997.

OLIVEIRA, L.D.; DUARTE, J.M.B. Tempo de trânsito gastr-intestinal em cervídeos sul americanos e suas implicações ecológicas e evolutivas. In: CONGRESSO BRASILEIRO DE MASTOZOOLOGIA, 2., Belo Horizonte, Resumo. P.281282. 2003.

ORÓ, J.; NOONER, D.W.; WIKSTRON, S.A. Paraffinic hydrocarbons in pasture plants. Science, v. 147, n. 3659, p. 870-873, 1965.

PARKER, K. Advances in the nutritional ecology of cervids at different scales. Écoscience, v. 10, p. 395-411, 2003. 
PARKER, K.L.; GILLINGHAM, T.A.; HANLEY, T.A. et al. Foraging efficiency: Energy expenditure versus energy gain in free-ranging black-tailed deer. Canadian Journal of Zoology, v. 74, p. 442-450, 1996.

PARKER, K.L.; GILLINGHAM, T.A.; HANLEY, T.A. et al. Energy and protein balance of free-ranging black-tailed deer in a natural forest environment. Wildlife Monographs, v. 143, p. 1-48, 1999.

PAUTASSO, A.A.; PEÑA, M.I. Estado de conocimiento actual y registros de mortalidad de Ozotoceros bezoarticus en la provincia de Santa Fe, Argentina. Deer Specialist Group News, v. 17, p. 14-15, 2002.

PEKINS, P.J.; SMITH, K.S.; MAUTZ, W.W. The energy cost of gestation in whitetailed deer. Canadian Journal of Zoology, v. 76, p. 1091-1097, 1998.

PINDER, L.; LEEUWENBERG, F. Veado-catingueiro (Mazama gouazoubira, Fisher 1814). In DUARTE, J.M.B. (Ed.). Biologia e conservação de cervídeos sulamericanos: Blastocerus, Ozotoceros e Mazama. Jaboticabal. FUNEP, 1997. cap. 4, p. 60-68.

REDFORD, K.H. The pampas deer (Ozotoceros bezoarticus) in Central Brasil. In: WEMMER,C.M. (Ed). Biology and management of Cervidae. Washington: Smithsonian Institution Press, 1987. p. 410-414.

ROBBINS, C.T. Wildlife feeding and nutrition. New York: Academic Press, 1993. $352 \mathrm{p}$.

RODRIGUES, F.H.G. História natural e biologia comportamental de veado campeiro (Ozotoceros bezoarticus) em cerrado do Brasil Central. Campinas, 1996a. 89 p. Dissertação (Mestrado) - Instituto de Biologia, Universidade Estadual de Campinas.

RODRIGUES, F.H.G. História natural e biologia comportamental de veado campeiro no Parque Nacional das Emas. In. ENCONTRO NACIONAL DA SOCIEDADE BRASILEIRA DE ETOLOGIA, Uberlândia, 1996b. Anais. Uberlândia: SBE, 1996b. p.223-231.

RODRIGUES, F.H.G. Influência do fogo e da seca na disponibilidade de alimento para herbívoros do cerrado. In: MIRANDA, H.S.; SAITO,C.H. e DIAS, B.F.S. (Ed). Impactos de queimadas em áreas de cerrado e restinga. Brasília: Editora da Universidade de Brasília, 1996c. p. 73-83.

RODRIGUES, F.H.G. Estimating pampas deer population in Emas National Park, Brasil. Deer Specialist Group News, v. 18, p. 10-12, 2003. 
RODRIGUES, F.H.G.; MONTEIRO-FILHO, E.L.A. Comensalistic relation between pampas deer, Ozotoceros bezoarticus (Mammalia:Cervidae) and rheas, Rhea americana (Aves: Rheidae). Brenesia, v. 45, p. 187-188, 1996.

RODRIGUES, F.H.G.; MONTEIRO-FILHO, E.L.A. Feeding behaviour of the pampas deer: a grazer or a browser? Deer Specialist Group News, v. 15, p. 12, 1999.

RODRIGUES, F.H.G.; MONTEIRO-FILHO, E.L.A. Home range and activity patterns of Pampas Deer in Emas National Park, Brazil. Journal of Mammalogy, v.81, n.4, p.1136-1142, 2000.

RU, Y.J.; GLATZ, P.C. Energy and protein requirements of fallow deer under a Mediterranean environment. In: RURAL INDUSTRIES RESEARCH AND DEVELOPMENT CORPORATION, Report. Barton: RIRDC, 2004. p.51. (Publication, 02/110).

SAS INSTITUTE. SAS/SAT: user's guide. Cary, 1999. 1v.

SCHNEIDER, B.H.; FLATT, W.P. The evaluation of feeds through digestibility experiments. Athens: Univ. Georgia Press, 1975. 423p.

SCHOELLER, D.A.; VAN SANTEN, E. Measurements of energy expenditure in humans by doubly labeled water method. Journal of Applied Physiology, v. 53, p. 955-959, 1982.

SCHOELLER, D.A.; RAVUSSIN,E.; SCHUTZ,Y. et al. Energy expenditure by labeled water: validation in humans and proposed calculation. American Physiology Society, v. 250. p. 823-830, 1986.

SEMIADI, G.; HOLMES, C.W.; BARRY, T.N. et al. The efficiency of utilization of energy and nitrogen in young sambar (Cervus unicolor) and red deer (Cervus elaphus). Journal of Agricultural Science, v.130, p.193-198, 1998.

SILVEIRA, L.; RODRIGUES, F.H.G.; JACOMO,A.T. Impact of wildfires on the megafauna of Emas National Park, Central Brazil. Oryx, v.33, p.108-114, 1999.

SMITH, D.G.; MAYES, R.W.; RAATS, J.G. Effect of species, plant part, and season of harvest on n-alkane concentrations in the cuticular wax of common rangeland grasses from southern Africa. Australian Journal of Agricultural Research, v.52, p.875-882, 2001. 
SPEAKMAN, J.R.; RACEY P.A. The double-labeled water technique for measurement of energy expenditure in free-living animals. Science Progress. v. 72 , n. 286 , p. $227-237,1988$.

TORIEN, C.A.; SAHLU,T.; WONG,W.W. Energy expenditure of angora bucks in peak breeding season estimated with doubly labelled water technique. Journal of Animal Science, v.77, p.3096-3105, 1999.

ULLREY,D.E.; YOUATT,W.G.; JOHSON,H.E. et al. Protein requirement of whitetailed deer fawns. Journal of Wildlife Management, v. 31, p. 679-685, 1967.

ULLREY,D.E.; YOUATT,W.G.; JOHSON,H.E. et al. Digestible and metabolizable energy requirements for winter maintenance of Michigan white-tailed does. Journal of Wildlife Management, v. 34, p. 863-869, 1970.

UNTZ, G. Manuel pratique de chromatographie en phase gazeuse. 3. ed. Paris: Masson, 1982. p. 72.

VALIENTE, O.L.; DELGADO, P.; VEGA, A.de et al. Validation of the n-alkane technique to estimate intake, digestibility, and diet composition in sheep consuming mixed grain:roughage diets. Australian Journal of Agricultural Research, v. 54, p. 693-702, 2003.

VAN DER EEMS, K.L.; BROWN, R.D.; GUNDBURG, C.M. Circulating levels of 1,25 dihydroxy vitamin $\mathrm{D}$, alkaline phosphatase, hydroplorine and osteocalin associated with antler growth in white-tailed deer. Acta Endocrinology, v. 118, p. $407-414,1988$.

VAN SOEST, P.J. Nutritional ecology of the ruminant. 2. ed. New York: Cornell University, 1994. 476p.

VERME, L.J.; ULLREY, D.E. White-tailed deer: ecology and management. Washington: A Wildlife Management Institute Book, 1984. 870 p.

WALKER, E. Mammals of the world. Baltimore: John Hopkins University Press, 1991. $1398 \mathrm{p}$.

WEMMER, C.M. Biology and management of the cervidae. Washington: Park Smithsonian Institution, 1982. 577 p.

WEMMER, C.M. Pampas deer updates. Deer Specialist Group News, v. 12, p. 3, 1994. 